\title{
BAHASA INDONESIA UNTUK PERGURUAN TINGGI
}

Sukirman Nurdjan, S.S., M.Pd.

Firman, S.Pd., M.Pd.

Mirnawati, S.Pd., M.Pd.

Aksara Timur

2016 


\section{BAHASA INDONESIA UNTUK PERGURUAN TINGGI}

Sukirman Nurdjan, S.S., M.Pd.

Firman, S.Pd., M.Pd.

Mirnawati, S.Pd., M.Pd.

ISBN: 978-602-73433-6-8

\section{Desain Sampul \& Tata Letak:}

Andi Hafizah Qurrota A'yun

\section{Penerbit:}

Penerbit Aksara Timur

\section{Alamat Kantor}

JI. Pajjaiyang Kumalasari Pintu II Blok AC 2 No. 4 Daya Makassar

Sulawesi Selatan Mobile phone: 08114121449

E-mail: penerbitaksaratimur@gmail.com FB: Penerbit Aksara Timur

Ukuran: 14 X 21cm; Halaman: vi + 152

Cetakan Pertama, Agustus 2016

Hak cipta dilindungi undang undang

Dilarang mengutip atau memperbanyak tanpa izin dari penerbit 


\section{KATA PENGANTAR}

Mata kuliah Bahasa Indonesia merupakan salah sastu mata kuliah yang diberikan kepada mahasiswa sebagai instrumen pengembangan kepribadian mahasiswa menuju terbentuknya masyrakat terpelajar yang mahir berkomunikasi dalam bahasa Indonesia baik secara tertulis maupun secara lisan.

Mahasiswa perlu ditingkatkan kesadarannya bahwa bahasa Indonesia adalah alat komunikasi paling penting untuk mempersatukan seluruh bangsa Indonesia. Hal ini mengingat bahasa Indonesia merupakan alat mengungkapkan diri baik secara lisan maupun tertulis, dari segi rasa, karsa, dan cipta, serta pikir, baik secara etis, estetis, maupun secara logis. Warga negara Indonesia yang mahir berbahasa Indonesia yang akan dapat menjadi warga negara yang mampu memenuhi kewajibannya di mana pun mereka berada di wilayah tanah air dan dengan siapa pun mereka bergaul di wilayah NKRI. Oleh karena itu, bahasa Indonesia masuk ke dalam kelompok mata kuliah pengembangan kepribadian mahasiswa, yang kelak sebagai insan terpelajar akan terjun ke dalam kancah kehidupan berbangsa dan bernegara sebagai pemimpin dalam lingkungannya masing-masing.

Buku ini sangat terbuka dan terus dilakukan perbaikan dan penyempurnaan dimasa mendatang. Untuk itu, kami 
mengundang para pembaca memberikan kritik, saran dan masukan untuk perbaikan dan penyempurnaan pada edisi berikutnya. Atas kontribusi tersebut, kami ucapkan terima kasih. Mudah-mudahan kita dapat memberikan yang terbaik bagi kemajuan dunia pendidikan dalam rangka mempersiapkan generasi emas Indonesia..

Palopo, Agustus 2016

Tim Penyusun 
Kata Pengantar-iii

\section{DAFTAR ISI}

Daftar Isi-v

\section{BAB I SEJARAH DAN PERKEMBANGAN BAHASA INDONESIA}
A. Sejarah Perkembangan Bahasa Indonesia - 1
B. Peristiwa-peristiwa penting berkaitan dengan
Perkembangan Bahasa Indonesia - 7
C. Fungsi dan Kedudukan Bahasa Indonesia - 17

\section{BAB II BAHASA INDONESIA RAGAM ILMIAH}
A. Pengertian dan Karakteristik Bahasa Indonesia Ragam IImiah - 23
B. Berbagai Ragam Bahasa - 24
C. Menggunakan Bahasa Indonesia Ragam Ilmiah dalam Menulis dan Presentasi IImiah - 26

\section{BAB III DIKSI (PILIHAN KATA)}
A. Kaidah Makna - 28
B. Penggunaan Pilihan Kata (Diksi) - 37

BAB IV PEMBENTUKAN DAN PERLUASAN KALIMAT
A. Pendahuluan - 42
B. Pengertian Kalimat - 42
C. Bagian-Bagian Kalimat - 44
D. Kalimat Tunggal - 46
E. Kalimat Majemuk Setara - 48
F. Kalimat Majemuk Bertingkat - 49
G. Jenis Konjungsi - 53

BAB V PEMBENTUKAN PARAGRAF
A. Pendahuluan - 55
B. Pengertian Paragraf - 55
C. Struktur Paragraf - 56
D. Tujuan Pembentukan Paragraf - 57
E. Jenis-jenis Paragraf - 59 

F. Syarat Pembentukan Paragraf - 61
G. Teknik Pengembangan Paragraf - 65
H. Cara Penempatan Pikiran Utama - 66
I. Pola Pengembangan Paragraf - 74

\section{BAB VI KETERAMPILAN MEMBACA}
A. Teknik Membaca SQ3R-83
B. Teknik Membaca skimming dan scanning -89
C. Usaha dan Potensi Membaca-90
D. Membaca Tulisan IImiah-92

BAB VIII KETERAMPILAN MENULIS
A. Menulis Surat-98
B. Menulis Makalah-112
C. Karya Reproduksi Bacaan-119

BAB IX KETERAMPILAN BERBICARA
A. Presentasi-130
B. Seminar-136
C. Berpidato dalam Situasi Formal-139

DAFTAR PUSTAKA-151 


\section{BAB I \\ SEJARAH DAN PERKEMBANGAN \\ BAHASA INDONESIA}

\section{A. Sejarah Perkembangan Bahasa Indonesia}

D ahasa Melayu adalah bahasa kebanggaan Brunei, Indonesia, Malaysia, dan Singapura. Bahasa Indonesia yang berkedudukan sebagai bahasa kebangsaan dan bahasa resmi negara Republik Indonesia merupakan sebuah dialek bahasa Melayu, yang pokoknya dari bahasa Melayu Riau (bahasa Melayu di Provinsi Riau, Sumatra, Indonesia). Nama Melayu pertama digunakan sebagai nama kerajaan tua di daerah Jambi di tepi Sungai Batanghari, yang pada pertengahan abad ke-7 ditaklukkan oleh kerajaan Sriwijaya. Selama empat abad kerajaan ini berkuasa di daerah Sumatra Selatan bagian timur dan dibawa pemerintahan raja-raja Syailendra bukan saja menjadi pusat politik di Asia Tenggara, melainkan juga menjadi pusat ilmu pengetahuan.

Berdasarkan beberapa prasasti yang ditemukan, yaitu Kedukan Bukit (683), Talang Tuwo (684), Telaga Batu (tidak berangka tahun), Kota Kapur, Bangka (686), dan Karang Brahi(686) membuktikan bahwa kerajaan Sriwijaya menggunakan bahasa Melayu, yaitu yang biasa disebut Melayu Kuno, sebagai bahasa resmi dalam pemerintahannya. Dengan kata lain, prasasti-prasasti itu menunjukkan bahwa pada abad ke-7 bahasa Melayu telah digunakan sebagai bahasa resmi di daerah kekuasaan Sriwijaya yang bukan hanya di Sumatra, melainkan juga di Jawa dengan ditemukannya prasasti Gandasuli di Jawa Tengah (832) dan didekat Bogor (942). Di Samping, sebagai bahasa resmi pemerintahan, bahasa Melayu juga sudah digunakan sebagai bahasa kebudayaan, yaitu ba- 
hasa pengantar dalam mempelajari ilmu agama dan bahasa perdagangan.

Sekitar awal abad ke-15 kerajaan Malaka di Semenanjung berkembang dengan sangat cepat menjadi pusat perdagangan dan pusat pertemuan para pedagang dari Indonesia, Tiongkok, dan dari Gujarat. Para pedagang dari Jawa pada waktu itu dikuasai oleh Majapahit membawa rempah-rempah, cengkih, dan pala dari Indonesia Timur ke Malaka. Hasil Bumi di Sumatra yang berupa Kapur barus, lada kayu cendana, dan yang lainnya dibawa ke Malaka oleh para pedagang dari Sumatra. Di Malaka mereka membeli barangbarang dagangan yang dibawa oleh para pedagang dari Tiongkok dan Gujarat berupa sutera dari India, kain pelikat dari Koromandel, minyak wangi dari Persia, kain dari Arab, kain sutera dari Cina, kain bersulam emas dari Tiongkok, kain satin, kipas dari Tiongkok, dan barang-barang perhiasan yang lain.

Letak kota pelabuhan Malaka sangat menguntungkan bagi lalu lintas dagang melalui laut dalam abad ke-14 dan 15. Semua kapal dari Tiongkok dan Indonesia yang akan berlayar ke barat melalui Selat Malaka. Demikian pula semua kapal dari negara-negara yang terletak di sebelah barat Malaka apabila berlayar ke Tiongkok atau ke Indonesia juga melalui Selat Malaka, sebab pada saat itu, Malaka adalah satusatunya kota pelabuhan di selat Malaka. oleh karena itu, Malaka menguasai perdagangan antara negara-negara yang terletak di daerah utara, barat, dan timurnya.

Perkembangan Malaka yang sangat cepat berdampak positif terhadap bahasa Melayu. Sejalan dengan lalu lintas perdagangan, bahasa Melayu yang digunakan sebagai bahasa perdagangan dan juga penyiaran agama Islam dengan cepat tersebar ke seluruh Indonesia, dari Sumatra sampai ke kawasan timur Indonesia. 
Perkembangan Malaka sangat cepat, tetapi hanya sebentar karena pada tahun 1511 Malaka ditaklukkan oleh angkatan laut Portugis dan pada tahun 1641 ditaklukkan pula oleh Belanda. Dengan kata lain, Belanda telah menguasai hampir seluruh Nusantara.

Belanda, seperti halnya negara asing yang lain sangat tertarik dengan rempah-rempah Indonesia. Mereka tidak puas kalau hanya menerima rempah-rempah dari pedagang Gujarat. Oleh karena itu, mereka datang sendiri ke daerahdaerah rempah itu. Pada tahun 1596 datanglah pedagang Belanda ke daerah Banten di bawah nama VOC (Vereenigde Oost Indische Compagnie). Tujuan utama mereka adalah untuk berdagang, tetapi sejak tahun 1799 diambil alih oleh pemerintah Belanda. Dengan demikian, tujuannya bukan hanya untuk berdagang, melainkan juga untuk tujuan sosial dan pendidikan.

Masalah yang segera dihadapi oleh Belanda adalah masalah bahasa pengantar. Tidak ada pilihan lain kecuali bahasa Melayu yang dapat digunakan sebagai bahasa pengantar karena pada saat itu bahasa Melayu secara luas sudah digunakan sebagai lingua franca di seluruh Nusantara. Pada tahun 1521 Pigafetta yang mengikuti pelayaran Magelhaens mengelilingi dunia, ketika kapalnya berlabuh di Todore menuliskan kata-kata Melayu. Hal ini membuktikan bahwa bahasa Melayu yang berasal dari Indonesia sebelah barat itu telah tersebar luas sampai ke daerah Indonesia sebelah Timur.

Dari hari ke hari kedudukan bahasa Melayu sebagai lingua franca semakin kuat, terutama dengan tumbuhnya rasa persatuan dan kebangsaan di kalangan pemuda pada awal abad ke-20 sekalipun mendapat rintangan dari pemerintah dan segolongan orang Belanda yang berusaha keras menghalangi perkembangan bahasa Melayu dan berusaha men- 
jadikan bahasa Belanda sebagai bahasa nasional di Indonesia. Para pemuda yang bergabung dalam berbagai organisasi, para cerdik pandai bangsa Indonesia berusaha keras mempersatukan rakyat. Mereka sadar bahwa hanya dengan persatuan seluruh rakyat bangsa Indonesia dapat menghalau kekuasaan kaum penjajah dari bumi Indonesia dan mereka sadar juga hanya dengan bahasa Melayu mereka dapat berkomunikasi dengan rakyat. Usaha mereka mempersatukan rakyat, terutama para pemudanya memuncak pada Kongres Pemuda di Jakarta pada tanggal 28 Oktober 1928. Dalam kongres itu para pemuda dari berbagai organisasi pemuda mengucapkan ikrar mengaku berbangsa satu, bangsa Indonesia; mengaku bertanah air satu, tanah air Indonesia; dan menjunjung tinggi bahasa persatuan, bahasa Indonesia.

Demikianlah, tanggal 28 Oktober merupakan hari yang amat penting, merupakan hari pengangkatan atau penobatan bahasa Indonesia sebagai bahasa persatuan atau sebagai bahasa nasional. Pengakuan dan pernyataan yang diikrarkan pada tanggal 28 Oktober 1928 itu tidak akan ada artinya tanpa diikuti usaha untuk mengembangkan bahasa Indonesia, meningkatkan kemampuan bahasa Indonesia sebagai bahasa nasional. Sebagai realisasi usaha itu, pada tahun 1939 para cendekiawan dan budayawan Indonesia menyelenggarakan suatu kongres, yaitu Kongres Bahasa Indonesia I di Solo, Jawa Tengah. Dalam Kongres itu Ki Hajar Dewantara menegaskan bahwa "jang dinamakan 'Bahasa Indonesia' jaitoe bahasa Melajoe jang soenggoehpoen pokoknja berasal dari 'Melajoe Riaoe', akan tetapi jang soedah ditambah, dioebah ataoe dikoerangi menoeroet keperloean zaman dan alam baharoe, hingga bahasa itoe laloe moedah dipakai oleh rakjat di seloeroeh Indonesia; ....". Oleh karena itu, kongres pertama ini memutuskan bahwa buku-buku tata bahasa yang 
sudah ada tidak memuaskan lagi, tidak sesuai dengan perkembangan bahasa Indonesia sehingga perlu disusun tata bahasa baru yang sesuai dengan perkembangan bahasa.

Hingga berakhirnya kekuasaan Belanda di Indonesia pada tahun 1942 tidak satu keputusan pun yang telah dilaksanakan karena pemerintahan Belanda tidak merasa perlu melaksanakan keputusan itu. Setelah masa pendudukan Jepang Bahasa Indonesia memperoleh kesempatan berkembang karena pemerintah Jepang, seperti halnya pemerintah penjajah yang lain sesungguhnya bercita-cita menjadikan bahasa Jepang menjadi bahasa resmi di Indonesia terpaksa menggunakan bahasa Indonesia sebagai bahasa resmi pemerintahan dan sebagai bahasa pengantar di sekolah-sekolah. Perkembangan berjalan dengan sangat cepat sehingga pada waktu kemerdekaan Indonesia diproklamasikan pada tanggal 17 Agustus 1945, bahasa Indonesia telah siap menerima kedudukan sebagai bahasa negara, seperti yang tercantum dalam Undang-undang Dasar 1945, Bab XV, Pasal 36.

Setelah Proklamasi kemerdekaan pada tahun 1945 bahasa Indonesia semakin mantap kedudukannya. Perkembangannya juga cukup pesat. Sehari sesudah proklamasi kemerdekaan, pada tanggal 18 Agustus ditetapkan Undangundang Dasar 1945 yang di dalamnya terdapat pasal, yaitu pasal 36, yang menyatakan bahwa "Bahasa Negara ialah Bahasa Indonesia." Dengan demikian, selain berkedudukan sebagai bahasa negara juga, bahasa Indonesia dipakai dalam semua urusan yang berkaitan dengan pemerintahan dan negara.

Sesudah kemerdekaan, bahasa Indonesia mengalami perkembangan yang pesat. setiap tahun jumlah pemakai bahasa Indonesia bertambah. Kedudukan bahasa Indonesia sebagai bahasa nasional dan bahasa negara juga semakin 
kuat. Perhatian terhadap bahasa Indonesia baik di pemerintah maupun masyarakat sangat besar. Pemerintah Orde Lama dan Orde Baru menaruh perhatian yang besar terhadap perkembangan bahasa Indonesia di antaranya melalui pembentukan lembaga yang mengurus masalah kebahasaan yang sekarang menjadi Pusat Bahasa dan Penyelenggaraan Kongres Bahasa Indonesia. Perubahan ejaan bahasa Indonesia dari Ejaan van Ophuijsen ke Ejaan Soewandi hingga Ejaan yang Disempurnakan selalu mendapat tanggapan dari masyarakat.

Dalam era globalisasi sekarang ini, bahasa Indonesia mendapat saingan berat dari bahasa Inggris karena semakin banyak orang Indonesia yang belajar dan menguasai bahasa Inggris. Hal ini, tentu saja merupakan hal yang positif dalam rangka mengembangkan ilmu dan teknologi. Akan tetapi, ada gejala semakin mengecilnya perhatian orang terhadap bahasa Indonesia. Tampaknya orang lebih bangga memakai bahasa Inggris daripada bahasa Indonesia. Bahasa Indonesia yang dipakai juga banyak dicampur dengan bahasa Inggris. kekurangpedulian terhadap bahasa Indonesia akan menjadi tantangan yang berat dalam pengembangan bahasa Indonesia.

Pada awal tahun 2004, Dewan Bahasa dan Pustaka (Malaysia) dan Majelis Bahasa Brunai Darussalam - Indonesia - Malaysia (MABBIM) mencanangkan Bahasa Melayu dijadikan sebagai bahasa resmi ASEAN dengan memandang lebih separuh jumlah penduduk ASEAN mampu bertutur dalam bahasa Melayu. Walaupun demikian, gagasan ini masih dalam perbincangan.

Melalui perjalanan sejarah yang panjang bahasa Indonesia telah mencapai perkembangan yang luar biasa, baik dari segi jumlah penggunanya, maupun dari segi sistem tata bahasa dan kosakata serta maknanya. Sekarang bahasa 
Indonesia telah menjadi bahasa besar yang digunakan dan dipelajari tidak hanya di seluruh Indonesia tetapi juga di banyak negara bahkan kebersihan Indonesia dalam mengajarkan bahasa Indonesia kepada generasi muda telah dicatat sebagai prestasi dari segi peningkatan komunikasi antarwarga negara Indonesia.

\section{B. Peristiwa-peristiwa penting berkaitan dengan perkembangan bahasa Indonesia}

1. Kelahiran Bahasa Indonesia Secara Politis

Bahasa Melayu yang semakin lama semakin kaya dengan adanya pengaruh bahasa-bahasa lain tersebut sampai dengan menjelang akhir tahun 1928 secara resmi masih tetap bernama bahasa Melayu, walaupun dilihat dari segi fungsinya sudah tidak lagi mencerminkan sebagai bahasa daerah. Atas kesadaran para pemuda (yang tergabung dalam berbagai organisasi pemuda saat itu) akan pentingnya bahasa sebagai alat pemersatu bangsa, maka pada Kongres Pemuda di Jakarta tanggal 28 Oktober 2928 dicetuskan dalam ikrar politik yang disebut dengan nama Sumpah Pemuda. Bunyi ikrar tersebut adalah sebagai berikut:

1) Kami poetera dan poeteri Indonesia, mengakoe berbangsa yang satoe bangsa Indonesia;

2) Kami poetera dan poeteri Indonesia, mengakoe bertanah air yang satu tanah air Indonesia;

3) Kami poetera dan poeteri Indonesia, menjoenjoeng bahasa persatoean bahasa Indonesia.

Sejak diikrarkannya Sumpah Pemuda tersebut berarti secara resmi bahasa Indonesia telah lahir. Namun demikian, karena kelahiran itu terwujud dalam rangka ikrar politis, maka kelahiran tersebut juga disebut kelahiran politis. Secara formal pemerintah yang berkuasa saat itu (Pemerintah Hindia Belanda) tetap menyatakan bahwa bahasa yang dipakai oleh 
pribumi (sebutan orang Indonesia pada saat itu) adalah bahasa Melayu.

Walaupun pemerintah Hindia Belanda belum mengakui bahasa Indonesia sebagai bahasa Persatuan bagi rakyat Indonesia, namun dampaknya semakin terasa. Dampak tersebut berupa semakin menggebunya semangat persatuan para pemuda. Persatuan tersebut disadari sepenuhnya sebagai modal dasar untuk mengusir penjajah.

2. Kelahiran Bahasa Indonesia Secara Yuridis

Upaya para pemuda untuk mengusir penjajah dengan modal dasar semangat persatuan tersebut akhirnya membuahkan hasil berupa Kemerdekaan Bangsa Indonesia yang diproklamasikan oleh Bung Karno dan Bung Hatta (atas nama bangsa Indonesia) pada tanggal 17 Agustus 1945. Sehari kemudian, yakni tanggal 18 Agustus 1945 Undangundang Dasar Negara Republik Indonesia Tahun 1945 (UUD 45) diundangkan. Salah satu dari pasal-pasal yang terdapat pada UUD 1945 tersebut, yakni Bab XV Pasal 36 berbunyi: Bahasa Negara ialah Bahasa Indonesia. Dengan demikian, berarti bahasa Indonesia secara resmi, secara yuridis, telah dinyatakan sebagai bahasa Negara atau bahasa Resmi.

Tahun-tahun penting yang mengandung arti sangat menentukan dalam sejarah perkembangan bahasa Melayu/Indonesia dapat dirinci sebagai berikut:

1. Pada tahun 1901 disusun ejaan resmi bahasa Melayu oleh Ch. A. van Ophuiysen dan dimuat dalam Kitab Logat Melayu.

2. Pada tahun 1908 pemerintah mendirikan sebuah badan penerbit buku-buku bacaan yang diberi nama Commissie voor de Volkslectur (Taman Bacaan Rakyat), yang kemudian pada tahun 1917 diubah menjadi Balai Pustaka. Balai Pustaka menerbitkan buku-buku novel, seperti Siti Nurbaya dan Salah Asuhan dan buku-buku penuntun 
bercocok tanam, penuntun memelihara kesehatan, yang tidak sedikit membantu penyebaran bahasa Melayu di kalangan masyarakat luas.

3. Tanggal 28 Oktober 1928 merupakan saat-saat yang paling menentukan dalam perkembangan bahasa Indonesia karena pada tanggal itulah para pemuda pilihan memancangkan tonggak yang kokoh untuk perjalanan bahasa Indonesia.

4. Pada tahun 1933 resmi berdiri sebuah angkatan sastrawan muda yang menamakan dirinya Pujangga Baru yang dipimpin oleh Sutan Takdir Ali Syahbana dan kawankawan.

5. Pada tanggal 25 - 28 Juni 1938 dilangsungkan Kongres Bahasa Indonesia I di Solo. Dari hasil kongres di Solo ini dapat disimpulkan bahwa usaha pembinaan dan pengembangan bahasa Indonesia telah dilakukan secara sadar oleh cendekiawan dan budayawan kita saat itu.

6. Masa pendudukan Jepang (1942-1945) merupakan pula suatu masa penting. Jepang memilih bahasa Indonesia sebagai alat komunikasi resmi antara pemerintah Jepang dengan rakyat Indonesia karena niat menggunakan bahasa Jepang sebagai pengganti bahasa Belanda untuk alat komunikasi tidak terlaksana. Bahasa Indonesia juga dipakai sebagai bahasa pengantar di lembaga-lembaga pendidikan dan untuk keperluan ilmu pengetahuan.

7. Pada tanggal 18 Agustus 1945 ditandatanganilah UndangUndang Dasar 1945, yang salah satu pasalnya (Pasal 36) menetapkan bahasa Indonesia sebagai bahasa negara.

8. Pada tanggal 19 Maret 1947 diresmikan penggunaan Ejaan Republik (Ejaan Soewandi) sebagai pengganti Ejaan van Ophuysen yang berlaku sebelumnya.

9. Kongres Bahasa Indoneia II di Medan pada tanggal 28 Oktober - 2 November 1954 adalah juga salah satu per- 
wujudan tekad bangsa Indonesia untuk terus-menerus menyempurnakan bahasa Indonesia yang diangkat sebagai bahasa nasional dan ditetapkan sebagai bahasa negara.

10. Pada tanggal 16 Agustus 1972 Presiden Republik Indonesia meresmikan penggunaan Ejaan Bahasa Indonesia yang Disempurnakan melalui pidato kenegaraan di depan sidang DPR yang dikuatkan pula dengan Keputusan Presiden No. 57 tahun 1972.

11. Tanggal 31 Agustus 1972 Menteri Pendidikan dan Kebudayaan menetapkan Pedoman Umum Ejaan Bahasa Indonesia yang Disempurnakan dan Pedoman Umum Pembentukan Istilah resmi berlaku di seluruh Indonesia.

12. Kongres Bahasa Indonesia III yang diselenggarakan di Jakarta pada tanggal 28 Oktober - 2 November 1978 merupakan peristiwa yang penting bagi kehidupan bahasa Indonesia. Kongres yang diadakan dalam rangka peringatan hari Sumpah Pemuda yang kelima puluh ini, selain memperlihatkan kemajuan, pertumbuhan, dan perkembangan bahasa Indonesia sejak tahun 1928, juga berusaha memantapkan kedudukan dan fungsi bahasa Indonesia.

13. Kongres bahasa Indonesia IV diselenggarakan di Jakarta pada tanggal $21-26$ November 1983. Kongres ini diselenggarakan dalam rangka peringatan hari Sumpah Pemuda yang ke-55. Dalam putusannya disebutkan bahwa pembinaan dan pengembangan bahasa Indonesia harus lebih ditingkatkan sehingga amanat yang tercantum dalam Garis-Garis Besar Haluan Negara, yang mewajibkan kepada semua warga Negara Indonesia dengan baik dan benar, dapat tercapai semaksimal mungkin. Selain itu, kongres menugasi Pusat Pembinaan dan Pengembangan Bahasa untuk memantau hasil-hasil kongres sebelumnya kepada kongres berikutnya. 
14. Kongres Bahasa Indonesia $V$ juga diadakan di Jakarta pada tanggal 28 Oktober -3 November 1988. Kongres ini merupakan kongres yang terbesar dalam sejarah perkembangan bahasa Indonesia karena selain dihadiri oleh kira-kira tujuh ratus pakar bahasa Indonesia dari seluruh Nusantara, juga kongres ini diikuti oleh peserta tamu dari Negara sahabat, seperti Malaysia, Singapura, Brunai Darussalam, Belanda, Jerman, dan Australia. Kongres ke-5 ini dibuka oleh Presiden Soeharto di Istana Negara Jakarta. Kongres ini ditandai dengan dipersembahkannya karya besar Pusat Pembinaan dan Pengembangan Bahasa kepada seluruh pencinta bahasa di Nusantara, yakni berupa (1) Kamus Besar Bahasa Indonesia, (2) Tata Bahasa Baku Bahasa Indonesia, dan (3) buku-buku bahan penyuluhan bahasa Indonesia.

15. Kongres Bahasa Indonesia VI diselenggarakan di Jakarta pada tanggal 28 Oktober - 2 November 1993. Dalam kongres ini diselenggarakan pula pameran buku yang menyajikan 385 judul buku yang terdiri atas buku-buku yang berkaitan dengan kongres bahasa Indonesia, Sumpah Pemuda, Bahasa dan Sastra Indonesia, serta kamus berbagai bidang ilmu, antara lain Kimia, Matematika, Fisika, Biologi, Kedokteran, dan Manajemen. Selain itu, disajikan pula panel Sumpah Pemuda, foto kegiatan kebahasaan/kesastraan, dan peragaan komputer sebagai pengolah data kebahasaan.

16. Kongres Bahasa Indonesia VII diselenggarakan di Jakarta pada tanggal 26 - 30 Oktober 1998. Kongres ini melanjutkan program kegiatan dari kongres VI.

17. Kongres Bahasa Indonesia VIII diselenggarakan di Jakarta pada tanggal $14-17$ Oktober 2003. Kongres ini merupakan kongres yang terbesar dalam sejarah perkembangan bahasa Indonesia karena selain dihadiri 
oleh kira-kira seribu pakar bahasa Indonesia dari seluruh Nusantara, juga kongres ini diikuti oleh peserta tamu dari hampir seluruh negara. Di samping itu, dalam kongres ini dianugerahkan penghargaan bagi pejabat yang selalu menggunakan bahasa Indonesia dengan baik dan benar.

18. Kongres bahasa Indonesia tahun 2008

Dalam rangka peringatan 100 tahun kebangkitan nasional, 80 tahun Sumpah Pemuda, dan 60 tahun berdirinya Pusat Bahasa, pada tahun 2008 dicanangkan sebagai Tahun Bahasa 2008. Oleh karena itu, sepanjang tahun 2008 telah diadakan kegiatan kebahasaan dan kesusasteraan. Sebagai puncak dari seluruh kegiatan kebahasaan dan kesusasteraan serta peringatan 80 tahun Sumpah Pemuda, diadakan Kongres IX Bahasa Indonesia pada tanggal 28 Oktober-1 November 2008 di Jakarta. Kongres tersebut membahas lima hal utama, yakni bahasa Indonesia, bahasa daerah, penggunaan bahasa asing, pengajaran bahasa dan sastra, serta bahasa media massa. Kongres bahasa ini berskala internasional dengan menghadirkan para pembicara dari dalam dan luar negeri. Para pakar bahasa dan sastra yang selama ini telah melakukan penelitian dan mengembangkan bahasa Indonesia di luar negeri sudah sepantasnya diberi kesempatan untuk memaparkan pandangannya dalam kongres tahun ini.

19. Kongres bahasa Indonesia tahun 2013 Kongres yang berlangsung 28-31 Oktober 2013 di Hotel Grand Sahid Jaya, Jakarta diikuti oleh 1.168 peserta dari seluruh Indonesia, dan dari luar negeri antara lain dari Jepang, Rusia, Pakistan, Jerman, Belgia, Brunei Darussalam, Singapura, Malaysia, China, Italia, dan Timor Leste. KBI X merekomendasikan hal-hal sebagai berikut : 
1) Pemerintah perlu memantapkan kedudukan dan fungsi bahasa Indonesia melalui penerjemahan dan penerbitan, baik nasional maupun internasional, untuk mengejawantahkan konsep-konsep ipteks berbahasa Indonesia guna menyebarkan ilmu pengetahuan dan teknologi ke seluruh lapisan masyarakat.

2) Badan Pengembangan dan Pembinaan Bahasa perlu berperan lebih aktif melakukan penelitian, diskusi, penataran, penyegaran, simulasi, dan pendampingan dalam implementasi Kurikulum 2013 untuk mata pelajaran Bahasa Indonesia.

3) Badan Pengembangan dan Pembinaan Bahasa dan Badan Standar Nasional Pendidikan (BSNP) perlu bekerja sama dalam upaya meningkatkan mutu pemakaian bahasa dalam buku materi pelajaran.

4) Pemerintah perlu meningkatkan sosialisasi hasil-hasil pembakuan bahasa Indonesia untuk kepentingan pembelajaran bahasa Indonesia dalam rangka memperkukuh jati diri dan membangkitkan semangat kebangsaan.

5) Pembelajaran bahasa Indonesia perlu dioptimalkan sebagai media pendidikan karakter untuk menaikkan martabat dan harkat bangsa.

6) Pemerintah perlu memfasilitasi studi kewilayahan yang berhubungan dengan sejarah, persebaran, dan pengelompokan bahasa dan sastra untuk memperkukuh NKRI.

7) Pemerintah perlu menerapkan Uji Kemahiran Berbahasa Indonesia (UKBI) untuk menyeleksi dan mempromosikan pegawai, baik di lingkungan pemerintah maupun swasta, guna memperkuat jati diri dan kedaulatan NKRI, serta memberlakukan UKBI sebagai "paspor bahasa" bagi tenaga kerja asing di Indonesia. 
8) Pemerintah perlu menyiapkan formasi dan menempatkan tenaga fungsional penyunting dan penerjemah bahasa di lembaga pemerintahan dan swasta.

9) Untuk mempromosikan jati diri dan kedaulatan NKRI dalam rangka misi perdamaian dunia, Pemerintah perlu memperkuat fungsi Pusat Layanan Bahasa (National Language Center) yang berada di bawah tanggung jawab Badan Pengembangan dan Pembinaan Bahasa.

10) Kualitas dan kuantitas kerja sama dengan berbagai pihak luar negeri untuk menginternasionalkan bahasa Indonesia perlu terus ditingkatkan dan dikembangkan, baik di tingkat komunitas ASEAN maupun dunia internasional, dengan dukungan sumber daya yang maksimal.

11) Pemerintah perlu melakukan "diplomasi total" untuk menginternasionalkan bahasa Indonesia dengan melibatkan seluruh komponen bangsa.

12) Presiden/wakil presiden dan pejabat negara perlu melaksanakan secara konsekuen Undang-Undang RI Nomor 24 Tahun 2009 tentang Bendera, Bahasa, dan Lambang Negara, serta Lagu Kebangsaan dan Peraturan Presiden Nomor 16 Tahun 2010 tentang Penggunaan Bahasa Indonesia dalam Pidato Resmi Presiden dan/atau Wakil Presiden serta Pejabat Negara Lainnya.

13) Perlu ada sanksi tegas bagi pihak yang melanggar Pasal 36 dan Pasal 38 Undang-Undang Nomor 24 Tahun 2009 sehubungan dengan kewajiban menggunakan bahasa Indonesia untuk nama dan media informasi yang merupakan pelayanan umum. 
14) Pemerintah perlu menggiatkan sosialisasi kebijakan penggunaan bahasa dan pemanfaatan sastra untuk mendukung berbagai bentuk industri kreatif.

15) Pemerintah perlu lebih meningkatkan kerja sama dengan komunitas-komunitas sastra dalam membuat model pengembangan industri kreatif berbasis tradisi lisan, program penulisan kreatif, dan penerbitan buku sastra yang dapat diapresiasi siswa dan peminat sastra lainnya.

16) Pemerintah perlu mengoptimalkan penggunaan teknologi informatika dalam pembelajaran bahasa dan sastra Indonesia.

17) Pelindungan bahasa-bahasa daerah dari ancaman kepunahan perlu dipayungi dengan produk hukum di tingkat pemerintah daerah secara menyeluruh.

18) Badan Pengembangan dan Pembinaan Bahasa perlu meningkatkan perencanaan dan penetapan korpus bahasa daerah untuk kepentingan pemerkayaaan dan peningkatan daya ungkap bahasa Indonesia sebagai bahasa penjaga kemajemukan Indonesia dan pilar penting NKRI.

19) Pemerintah perlu memperkuat peran bahasa daerah pada jalur pendidikan formal melalui penyediaan kurikulum yang berorientasi pada kondisi dan kebutuhan faktual daerah dan pada jalur pendidikan nonformal/informal melalui pembelajaran bahasa berbasis komunitas.

20) Badan Pengembangan dan Pembinaan Bahasa perlu meningkatkan pengawasan penggunaan bahasa untuk menciptakan tertib berbahasa secara proporsional.

21) Pemerintah perlu mengimplementasikan kebijakan yang mendukung eksistensi karya sastra, termasuk 
produksi dan reproduksinya, yang menyentuh identitas budaya dan kelokalannya untuk mengukuhkan jati diri bangsa Indonesia.

22) Penggalian karya sastra harus terus digalakkan dengan dukungan dana dan kemauan politik pemerintah agar karya sastra bisa dinikmati sesuai dengan harapan masyarakat pendukungnya dan masyarakat dunia pada umumnya.

23) Pemerintah perlu memberikan apresiasi dalam bentuk penghargaan kepada sastrawan untuk meningkatkan dan menjamin keberlangsungan daya kreativitas sastrawan sehingga sastra dan sastrawan Indonesia dapat sejajar dengan sastra dan sastrawan dunia.

24) Lembaga-lembaga pemerintah terkait perlu bekerja sama mengadakan lomba-lomba atau festival kesastraan, khususnya sastra tradisional, untuk memperkenalkan sastra Indonesia di luar negeri yang dilakukan secara rutin dan terjadwal, selain mendukung festival-festival kesastraan tingkat internasional yang sudah ada.

25) Peran media massa sebagai sarana pemartabatan bahasa dan sastra Indonesia di kancah internasional perlu dioptimalkan.

26) Komisi Penyiaran Indonesia (KPI) perlu mengingatkan dan memberikan teguran agar lembaga penyiaran menggunakan bahasa Indonesia yang baik dan benar.

27) Komisi Penyiaran Indonesia (KPI) menerima usulan dari masyarakat untuk menyampaikan teguran kepada lembaga penyiaran yang tidak menggunakan bahasa Indonesia dengan baik dan benar.

28) Diperlukan kerja sama yang sinergis dari semua pihak, seperti pejabat negara, aparat pemerintahan dari pusat sampai daerah, media massa, Dewan Pers, 
dan Badan Pengembangan dan Pembinaan Bahasa, demi terwujudnya bahasa media massa yang logis dan santun.

29) Literasi pada anak, khususnya sastra anak, perlu ditingkatkan agar nilai-nilai karakter yang terdapat dalam sastra anak dipahami oleh anak.

30) Badan Pengembangan dan Pembinaan Bahasa harus memperkuat unit yang bertanggung jawab terhadap sertifikasi pengajar dan penyelenggara BIPA.

31) Badan Pengembangan dan Pembinaan Bahasa berkoordinasi dengan para pakar pengajaran BIPA dan praktisi pengajar BIPA mengembangkan kurikulum, bahan ajar, dan silabus yang standar, termasuk bagi Komunitas ASEAN.

32) Badan Pengembangan dan Pembinaan Bahasa memfasilitasi pertemuan rutin dengan SEAMEO Qitep Language, SEAMOLEC, BPKLN Kemendikbud, dan perguruan tinggi untuk menyinergikan penyelenggaraan pengajaran BIPA.

33) Pemerintah Indonesia harus mendukung secara moral dan material pendirian pusat studi/kajian bahasa Indonesia di luar negeri.

\section{Fungsi dan Kedudukan Bahasa Indonesia}

1. Bahasa Indonesia sebagai Bahasa Nasional

Di dalam kedudukannya sebagai bahasa nasional, bahasa Indonesia berfungsi sebagai (1) lambang kebanggaan nasional, (2) lambang identitas nasional, (3) alat pemersatu berbagai suku bangsa, dan (4) alat perhubungan antardaerah dan antarbudaya. Keempat fungsi bahasa Indonesia sebagai bahasa nasional di atas dimiliki oleh bahasa Indonesia sejak tahun 1928 sampai sekarang. 
a. Bahasa Indonesia sebagai Lambang Kebanggaan Nasional

Tidak semua bangsa di dunia mempunyai sebuah bahasa nasional yang dipakai secara luas dan dijunjung tinggi. Adanya sebuah bahasa yang dapat menyatukan berbagai suku bangsa yang berbeda merupakan suatu kebanggaan bagi bangsa Indonesia. ini menunjukkan bahwa bangsa Indonesia sanggup mengatasi perbedaan yang ada.

Fungsi bahasa Indonesia sebagai lambang kebanggaan nasional mencerminkan nilai-nilai sosial budaya yang mendasari rasa kebanggaan. Seluruh suku bangsa di Indonesia harus memiliki rasa kebanggaan berbahasa nasional. Atas dasar kebanggaan inilah bahasa Indonesia harus dipelihara dan dikembangkan. Bangsa Indonesia sebagai pemilik bahasa Indonesia harus merasa bangga menggunakan bahasa Indonesia secara baik dan benar.

b. Bahasa Indonesia sebagai Lambang Identitas Nasional

Indonesia terdiri atas berbagai suku bangsa yang budaya dan bahasanya berbeda. Untuk membangun kepercayaan diri yang kuat, sebuah bangsa memerlukan identitas. Identitas sebuah bangsa dapat diwujudkan di antaranya melalui bahasanya. Dengan adanya sebuah bahasa yang mengatasi berbagai bahasa yang berbeda, suku-suku bangsa yang berbeda dapat mengidentifikasikan diri sebagai satu bangsa melalui bahasa tersebut. Sebagai lambang identitas nasional, bahasa Indonesia harus dijunjung tinggi di samping bendera dan lagu kebangsaan. Di dalam pelaksanaan fungsi ini, bahasa Indonesia harus memiliki identitasnya tersendiri yang membedakannya dengan bahasa lain. 
c. Bahasa Indonesia sebagai Alat Pemersatu Berbagai Suku Bangsa

Sebuah bangsa yang terdiri atas berbagai suku bangsa yang budaya dan bahasanya berbeda dan mengalami masalah besar dalam melangsungkan kehidupannya. Perbeda-an dapat memecah belah bangsa tersebut. Dengan adanya bahasa Indonesia yang diakui sebagai bahasa nasional oleh semua suku bangsa yang ada, perpecahan ini dapat dihindari karena suku-suku bangsa tersebut merasa satu. Kalau tidak ada sebuah bahasa, seperti bahasa Indonesia, yang dapat menyatukan suku-suku bangsa yang berbeda, akan banyak muncul masalah perpecahan bangsa.

d. Bahasa Indonesia sebagai Alat Perhubungan Antardaerah dan Antarbudaya

Masalah yang dihadapi bangsa yang terdiri atas berbagai suku bangsa dengan budaya dan bahasa yang berbeda adalah komunikasi. Diperlukan sebuah bahasa yang dapat dipakai oleh suku-suku bangsa yang berbeda bahasanya sehingga mereka dapat berhubungan. Bahasa Indonesia sudah lama memenuhi kebutuhan ini. Sudah berabad-abad bahasa ini menjadi lingua franca di wilayah Indonesia.

Bahasa Indonesia perlu dibina dan dikembangkan untuk menunjukkan kepada bangsa lain tentang kekayaan nasional berupa pemilikan bahasa nasional Indonesia. Bahasa inilah yang telah berhasil menyatukan cita dan semangat masyarakat Indonesia yang majemuk. Nilainilai budaya yang berkadar nasional dikomunikasikan melalui bahasa Indonesia. 


\section{Bahasa Indonesia sebagai Bahasa Negara}

Di dalam kedudukannya sebagai bahasa negara, bahasa Indonesia berfungsi sebagai (1) bahasa resmi kenegaraan, (2) bahasa pengantar dalam dunia pendidikan, (3) alat perhubungan di tingkat nasional untuk kepentingan pembangunan dan pemerintahan, dan (4) alat pengembangan kebudayaan, ilmu pengetahuan, dan teknologi.

Fungsi bahasa Indonesia sebagai bahasa negara di atas harus betul-betul dilaksanakan di dalam kehidupan bangsa Indonesia. Setiap petugas negara harus memperhatikan fungsi bahasa Indonesia sebagai bahasa negara tersebut.

a. Bahasa Indonesia sebagai Bahasa Resmi Kenegaraan

Dalam Kaitan dengan fungsi ini, sebagai bahasa negara, bahasa Indonesia dipakai pada semua upacara, peristiwa, dan kegiatan kenegaraan, baik secara lisan maupun dalam bentuk tulisan. Pidato-pidato resmi, dokumen-dokumen, keputusan- keputusan,dan suratsurat resmi harus ditulis dalam bahasa Indonesia. Upacara-upacara kenegaraan juga dilangsungkan dengan bahasa Indonesia. Pemakaian bahasa Indonesia dalam acara-acara kenegaraan sesuai dengan UUD 1945 mutlak diharuskan. Tidak dipakainya bahasa Indonesia dalam hal ini dapat mengurangi kewibawaan negara karena hal tersebut merupakan pelanggaran terhadap UUD 1945.

Pelaksanaan fungsi bahasa Indonesia sebagai bahasa resmi kenegaraan, pemakai bahasa Indonesia di dalam pelaksanaan administrasi negara (pemerintah) perlu dibina dan dikembangkan. Penguasaan bahasa Indonesia perlu dijadikan salah satu faktor penentu di dalam pengembangan tugas pemerintah, seperti pada penerimaan pegawai baru dan kenaikan pangkat, baik sipil maupun militer, serta pemberian tugas khusus di 
dalam dan di luar negeri. Di samping itu, mutu kebahasaan yang dipakai pada siaran radio, televisi, dan surat kabar perlu ditingkatkan dan dikembangkan lebih baik lagi.

b. Bahasa Indonesia sebagai Bahasa Pengantar dalam Dunia Pendidikan

Dunia pendidikan di sebuah negara memerlukan sebuah bahasa yang seragam sehingga kelangsungan pendidikan tidak terganggu. Pemakaian lebih dari satu bahasa dalam dunia pendidikan akan mengganggu keefektifan pendidikan. Biaya pendidikan menjadi lebih hemat. Peserta didik dari tempat yang berbeda dapat saling berhubungan. Bahasa Indonesia merupakan satu-satunya bahasa yang dapat memenuhi kebutuhan akan bahasa yang seragam dalam pendidikan di Indonesia. Bahasa Indonesia telah berkembang pesat dan pemakaiannya sudah tersebar luas. Pemakaian bahasa Indonesia dalam dunia pendidikan tidak hanya terbatas pada bahasa pengantar, bahan- bahan ajar, tetapi juga pemakaian bahasa Indonesia. Oleh karena itu, fungsi bahasa Indonesia sebagai bahasa pengantar di dalam dunia pendidikan harus dilaksanakan mulai dari tingkat taman kanak-kanak sampai ke perguruan tinggi di seluruh Indonesia.

c. Bahasa Indonesia sebagai Alat Perhubungan di Tingkat Nasional untuk Kepentingan Pembangunan dan Pemerintahan

Kepentingan pembangunan dan pemerintahan di tingkat nasional memerlukan sebuah bahasa sebagai alat perhubungan sehingga komunikasi tidak terhambat. Kalau ada lebih dari satu bahasa yang dipakai sebagai alat perhubungan, keefektifan pembangunan, dan pemerintahan akan terganggu karena akan diperlukan 
waktu yang lebih lama dalam berkomunikasi. Bahasa Indonesia dapat mengatasi hambatan tersebut.

Perkembangan bahasa Indonesia pada mulanya memang ada yang meragukan kemampuannya sebagai sarana komunikasi dan interaksi manusia Indonesia, tetapi ternyata bahasa ini mampu mengungkapkan pikiran-pikiran yang cukup rumit melalui kreativitas pengguna bahasa yang bersangkutan terutama dalam kepentingan pembangunan dan pemerintahan.

d. Bahasa Indonesia sebagai Alat Pengembangan Kebudayaan, IImu Pengetahuan, dan Teknologi.

Pengembangan kebudayaan, ilmu pengetahuan, dan teknologi memerlukan bahasa. Hal ini dimaksudkan agar keperluan dalam pengembangan tersebut dapat dimengerti oleh masyarakat luas. Tanpa bahasa seperti ini, pengembangan kebudayaan, ilmu pengetahuan, dan teknologi akan mengalami hambatan karena proses pengembangannya akan memerlukan waktu yang lama dan hasilnya pun tidak akan tersebar secara luas.

Bahasa Indonesia merupakan satu-satunya bahasa di Indonesia yang memenuhi syarat sebagai alat pengembangan kebudayaan, ilmu pengetahuan, dan teknologi karena bahasa Indonesia telah dikembangkan untuk keperluan tersebut dan bahasa ini dimengerti oleh sebagian masyarakat Indonesia. Dalam kaitan dengan fungsi ini, bahasa Indonesia adalah alat yang memungkinkan untuk membina dan mengembangkan kebudayaan Indonesia yang memiliki ciri-ciri dan identitasnya sendiri yang membedakannya dengan kebudayaan daerah dan kebudayaan asing. 


\section{BAB II \\ BAHASA INDONESIA RAGAM ILMIAH \\ A. Pengertian dan Karakteristik Bahasa Indonesia Ragam IImiah}

Bahasa Indonesia ragam ilmiah merupakan salah satu bahasa Indonesia yang digunakan dalam menulis karya ilmiah. Sebagai bahasa yang digunakan untuk memaparkan fakta, konsep, prinsip, teori atau gabungan dari keempatnya, bahasa Indonesia diharapkan dapat menjadi media yang efektif untuk berkomunikasi ilmiah, baik secara tertulis maupun lisan. Selanjutnya, Bahasa Indonesia ragam ilmiah memiliki karakteristik cendekia, lugas dan jelas, menghindari kalimat fragmentaris, bertolak dari gagasan, formal dan objektif, ringkas dan padat, dan konsisten.

Bahasa Indonesia bersifat cendekia menunjukkan bahwa bahasa Indonesia itu mampu digunakan secara tepat untuk mengungkapkan hasil berpikir logis, yakni mampu membentuk pernyataan yang tepat dan seksama. Sementara itu, sifat lugas dan jelas dimaknai bahwa bahasa Indonesia mampu menyampaikan gagasan IImiah secara jelas dan tepat. Untuk itu, setiap gagasan diungkapkan secara langsung sehingga makna yang ditimbulkan adalah makna lugas. Bahasa Indonesia ragam ilmiah juga menghindari penggunaan kalimat fragmentaris. Kalimat fragmentaris adalah kalimat yang belum selesai. Kalimat terjadi antara lain karena adanya keinginan penulis menggunakan gagasan dalam beberapa kalimat tanpa menyadari kesatuan gagasan yang diungkapkan.

Bahasa Indonesia ragam ilmiah mempunyai sifat bertolak dari gagasan. Artinya, penonjolan diadakan pada gagasan atau hal yang diungkapkan dan tidak pada penulis. Implikasinya, kalimat-kalimat yang digunakan didominasi oleh 
kalimat pasif. Sifat formal dan objektif ditandai antara lain oleh pilihan kosakata, bentuk kata, dan struktur kalimat. Kosakata yang digunakan bernada formal dan kalimat-kalimatnya memiliki unsur yang lengkap. Sementara itu, sifat ringkas dan padat direalisasikan dengan tidak adanya unsur-unsur bahasa yang mubazir. Hal itu berarti menuntut adanya penggunaan bahasa yang hemat. Terakhir, sifat konsisten yang ditampakkan pada penggunaan unsur bahasa, tanda baca, tandatanda lain, dan istilah yang sesuai dengan kaidah dan semuanya digunakan secara konsisten.

\section{B. Berbagai Ragam Bahasa}

Ragam bahasa yang digunakan dalam suasana akrab (santai) biasanya mempunyai kelainan jika dibandingkan dengan bahasa yang dipakai dalam suasana resmi. Dalam suasana akrab, penutur bahasa biasanya sering menggunakan kalimat-kalimat pendek, kata-kata dan ungkapan yang maknanya hanya dipahami dengan jelas oleh peserta percakapan itu. Sebaliknya, dalam suasana resmi, seperti dalam pidato resmi, ceramah ilmiah, perkuliahan, dalam rapat resmi biasanya digunakan kalimat-kalimat panjang, pilihan, dan ungkapan sesuai dengan tuntunan kaidah bahasa yang benar. Brenstein menamakan kedua ragam bahasa yang terakhir ini masing-masing sebagai ragam ringkas (restricted code) dan ragam lengkap (elaborate code).

1. Ragam Lisan dan Ragam Tulisan

Ragam suatu bahasa dapat juga dibedakan jenis kesatuan dasarnya (Halim, 1998). Dilihat dari wujud kesatuan dasar ini ragam bahasa dapat pula dibedakan antara ragam lisan dan ragam tulisan. Kesatuan dasar ragam tulisan adalah huruf. Tidak semua bahasa terdiri atas ragam lisan dan tulisan, tetapi pada dasarnya semua bahasa memiliki ragam lisan. 
Hubungan antara lisan dan ragam tulisan adalah timbal balik. Ragam tulisan melambangkan ragam lisan dengan pengertian bahwa kesatuan ragam tulisan melambangkan ragam tulisan, yaitu huruf melambangkan kesatuan-kesatuan dasar lisan, yaitu bunyi bahasa dalam bentuk yang dapat dilihat. Hubungan perlambangan antara kedua ragam bahasa itu tidak jarang menimbulkan kesan bahwa struktur lisan sama benar dengan struktur ragam tulisan. Dalam kenyataan, kedua ragam bahasa itu pada dasarnya berkembang menjadi dua sistem bahasa yang terdiri atas perangkat kaidah yang tidak seluruhnya sama. Ini berarti bahwa kaidah yang berlaku bagi ragam lisan belum tentu berlaku juga bagi ragam tulisan, kaidah yang mengatur menghilangkan unsur-unsur tertentu dalam kalimat ragam lisan, misalnya tidak berlaku seluruhnya bagi ragam tulisan, yang menuntut adanya kalimat-kalimat dalam bentuk selengkap mungkin.

Dalam hubungan bahasa Indonesia, perbedaan antara kaidah ragam lisan dan kaidah ragam tulisan telah berkembang sedemikian rupa, sesuai dengan perkembanganya sebagai bahasa perhubungan antara daerah dan antarsuku selama berabad-abad di seluruh Indonesia (Teew, 1961; Halim 1998).

a. Ragam Baku dan Ragam Nonbaku

Dalam pembicaraan seorang penutur selalu mempertimbangkan kepada siapa ia berbicara, di mana, tentang masalah apa, kapan, dan dalam suasana bagaimana. Dengan adanya pertimbangan semacam itu, timbullah ragam pemakaian bahasa sesuai dengan fungsi dan situasinya (Suwito, 1983).

Situasi di kantor, dalam berdiskusi, berpidato, memimpin rapat resmi, dan sebagainya merupakan situasi/suasana resmi (formal). Dalam situasi/suasana seperti ini hendaknya dipakai 
ragam resmi atau formal yang biasa disebut dengan istilah ragam bahasa baku atau dengan singkat ragam baku. Ragam baku ini selain digunakan dalam suasana, seperti yang telah disinggung di atas, juga digunakan dalam surat menyurat resmi, administrasi pemerintahan, perundang-undangan negara, dan dalam karya-karya ilmiah. Sebaliknya, situasi di dalam rumah tangga, di pinggir jalan, di warung-warung, di pasar, di lapangan olahraga, dan sebagainya merupakan situasi/ suasana yang tak resmi (informal). Dalam suasana, seperti ini hendaknya kita menggunakan ragam bahasa tak resmi (informal) yang biasanya disebut dengan istilah ragam bahasa tidak baku (nonbaku) atau dengan singkatan ragam tidak baku (nonbaku). Jadi, pemakaian bahasa di luar suasana formal (resmi) dan hanya berfungsi sebagai alat komunikasi antarsahabat, antaranggota keluarga di rumah, dan antarpembeli kesemuanya digolongkan ke dalam ragam tidak baku.

Kalau diperhatikan pemakaian kedua ragam bahasa itu, ragam baku adalah ragam bahasa yang dilambangkan dan diakui oleh sebagian besar warga masyarakat pemakaiannya dan dijadikan kerangka/ rujukan norma kaidah bahasa dalam pemakaiannya. Sebagai kerangka rujukan, ragam baku berisi rujukan yang menentukan benartidaknya pemakaian bahasa, baik ragam lisan maupun tulisan, sedangkan ragam tidak baku selalu ada kecenderungan untuk menyalahi norma/ kaidah bahasa yang berlaku.

\section{Menggunakan Bahasa Indonesia Ragam IImiah dalam Menulis dan Presentasi IImiah}

Menggunakan bahasa Indonesia ragam ilmiah dalam menulis dan presentasi ilmiah berarti memanfaatkan potensi bahasa Indonesia untuk memaparkan fakta, konsep, prinsip, teori, atau gabungan dari keempat hal tersebut secara hasil 
penelitian secara tertulis dan lisan. Itu berarti, pada saat menulis tulisan ilmiah penulis harus berusaha keras agar bahasa Indonesia yang digunakan benar-benar menunjukkan sifat yang cendikia, lugas dan jelas, menghindari kalimat fragmentaris bertolak dari gagasan, formal dan objektif, ringkas dan padat, dan konsisten. Sifat-sifat bahasa Indonesia yang demikian ditampakkan pada pilihan kata, pengembangan kalimat, pengembangan paragraf, kecermatan dalam menggunakan ejaan, tanda baca, dan aspek-aspek mekanik lainnya.

Bagaimana halnya dalam presentasi ilmiah? Ketika melakukan presentasi ilmiah, presenter dituntut agar bahasa Indonesia lisan yang digunakan diwarnai oleh sifat-sifat ragam bahasa Indonesia ilmiah sebagaimana dikemukakan di atas. Sementara itu, beberapa fasilitas dalam penggunaan bahasa lisan tetap dapat dimanfaatkan, misalnya adanya kesempatan untuk mengulang-ulang, menekankan dengan mengunakan intonasi, jeda, dan unsur suprasegmental lainnya. 


\section{A. Kaidah Makna}

\section{BAB III \\ DIKSI (PILIHAN KATA)}

aidah makna dalam pemilihan kata mengacu kepada persyaratan ketepatan pemilihan kata sebagai lambang objek pengertian atau konsep-konsep yang meliputi berbagai aspek. Jadi, makna adalah hubungan antara bentuk bahasa dan objek atau sesuatu yang diacunya. Ada dua jenis makna yang terpenting di antaranya adalah makna denotatif atau makna leksikal dan makna konotatif atau makna gramatikal.

\section{Kata yang Denotatif dan Kata yang Konotatif}

Kata denotatif atau biasa disebut makna leksikal adalah makna kata secara lepas tanpa kaitan dengan kata yang lain dalam sebuah struktur atau kata denotatif berhubungan dengan konsep denotatif, sedangkan kata yang konotatif berhubungan dengan konsep konotasi. Denotasi adalah konsep dasar yang didukung oleh kata, sedangkan nilai rasa atau gambaran tambahan yang ada di samping denotasi disebut konotasi.

Kata yang denotatif mengandung makna yang sebenarnya, makna kata yang sesuai dengan konsepnya sehingga disebut juga makna konseptual, makna yang sesuai dengan makna kata dalam kamus atau makna leksikal. Kata yang konotatif mengandung makna tambahan yang sesuai dengan sikap dan nilai rasa tertentu pengguna bahasa bersangkutan. Kata konotatif biasa juga disebut makna gramatikal atau makna struktural, yaitu makna yang timbul bergantung pada struktur tertentu sesuai dengan konteks dan situasi di mana kata itu berada. 
Contoh :

(1) Toko itu dilayani gadis-gadis cantik.

(2) toko itu dilayani dara-dara cantik

(3) toko itu dilayani perawan- perawan cantik.

Kata-kata gadis, dara, perawan secara denotatif maknanya sama, yaitu wanita atau wanita muda yang belum kawin, tetapi secara konotatif maknanya berbeda. Gadis mengandung makna umum, dara mengandung makna yang bersifat puitis, dan perawan mengandung makna asosiasi tertentu. Demikian pula kata-kata kelompok, rombongan, dan gerombolan secara denotatif bermakna kumpulan benda atau orang, tetapi secara konotatif dibedakan maknanya, yaitu kelompok dan rombongan berada dalam makna positif, sedangkan gerombolan dipahami dalam hubungan makna negatif.

Contoh :

(4) Kelompok anak mudah itu sedang asyik bermain musik.

(5) Ketua rombongan turis yang baru tiba dikalungi untaian bunga

(6) Gerombolan pengacau tersebut telah ditumpas habis.

Membahas suatu masalah yang bersifat ilmiah sebaiknya digunakan kata-kata yang denotatif. Kata-kata atau istilah harus bebas dari konotasi, sedangkan pada karya sastra lebih banyak digunakan kata-kata yang konotatif sebagai upaya merakit keindahan. Dalam kaitan makna kata terdapat beragam konotasi sosial, yaitu ada yang bersifat positif dan negatif, tinggi, rendah, sopan, dan porno, atau yang sakral. Misalnya, kata-kata karyawan, asisten, wisma, hamil, dan berpulang dianggap positif, baik, sopan, dan modern jika dibandingkan dengan kata-kata buruh, pembantu, pondok, bunting, dan mati yang dianggap 
negatif, kurang baik, kasar dan kuno. Agar dapat menyatakan gagasan dengan tepat, seseorang pembicara/ penulis harus dapat pula memilih kata-kata dengan konotasi yang tepat. Kata konotasi adalah kata-kata yang mengalami pergeseran dari makna kata leksikal.

\section{Kata yang Bersinonim dan Berhomonim}

Setiap kata biasanya tidak hanya melambangkan secara tepat satu objek atau satu konsep tetapi juga ada kata yang melambangkan beberapa makna dan sebaliknya ada beberapa kata yang melambangkan satu makna. Beberapa kata yang melambangkan satu makna tergolong kata yang bersinonim atau kata-kata sinonim. Sinonim adalah kata yang maknanya sama atau mirip dengan kata lain. Persamaan makna itu dapat tidak berlaku sepenuhnya. Namun, dalam kadar tertentu ada pertalian makna antara kata-kata yang berbeda itu.

Contohnya dapat terlihat pada penggunaan kata-kata indah, cantik, dan bagus yang mengandung makna yang sama tentang sesuatu yang sedap dipandang mata. Ketepatan kata-kata itu dalam penggunaannya bergantung pada ketepatan pilihan atas kata masing-masing. Misalnya, kita katakan pemandangan indah, gadis cantik, dan rumah bagus tentu saja akan terasa janggal atau kurang tepat jika dikatakan pemandagan cantik dan gadis bagus. Sinonim dapat juga diumpamakan sebagai nama lain dari suatu benda atau pengertian lain dari suatu ungkapan. Sebagai contoh, kata nasib dan takdir, kedua kata tersebut adalah sinonim dan relasinya selalu berlaku dua arah, yaitu dari takdir ke nasib atau dari nasib ke takdir. Sinonim dapat dibedakan sesuai dengan dimana posisi ia berada. 
Contoh,

\begin{tabular}{|l|l|}
\hline bentuk sinonim & contoh \\
\hline $\begin{array}{l}\text { sinonim antara } \\
\text { kalimat }\end{array}$ & Saya melihat dia dan dia kulihat \\
\hline $\begin{array}{l}\text { sinonim antara } \\
\text { frase }\end{array}$ & $\begin{array}{l}\text { Dua tangkai bunga dan bunga dua } \\
\text { tangkai }\end{array}$ \\
\hline $\begin{array}{l}\text { sinonim antara } \\
\text { kata }\end{array}$ & $\begin{array}{l}\text { Nasib dan takdir, memuaskan dan } \\
\text { menyenangkan }\end{array}$ \\
\hline $\begin{array}{l}\text { sinonim antara } \\
\text { morfem }\end{array}$ & $\begin{array}{l}\text { pemirsa dan pirsawan, kestabilan } \\
\text { dan stabilitas }\end{array}$ \\
\hline
\end{tabular}

Dua kata yang bersinonim dapat digabungkan sehingga memberi kesan yang lebih indah. Hasil penggabungan tersebut akan melahirkan kata majemuk. Hal yang harus dihindari dalam penggabungan kata adalah munculnya penggunaan kata secara berlebihan yang mengakibatkan terjadinya kata mubazir, misalnya adalah merupakan, agar supaya, maka dengan demikian, dan namun demikian. Di bawah ini disajikan beberapa contoh kata majemuk yang berupa kata penggabungan sinonim.

\begin{tabular}{|c|c|}
\hline $\begin{array}{l}\text { caci makai fakir } \\
\text { miskin gagah perkasa } \\
\text { kasih sayang sama } \\
\text { rata }\end{array}$ & $\begin{array}{l}\text { sunyi senyap sehat } \\
\text { walafiat warta berita } \\
\text { yatim piatu jungkir } \\
\text { balik }\end{array}$ \\
\hline
\end{tabular}

Antonim atau lawan makna adalah ungkapan yang maknanya kebalikan dari ungkapan yang lain. Misalya, kata mudah dan sukar, yaitu dua kata yang maknanya berlawanan dan relasi antonim selalu berlaku dua arah. Antonim dapat dibedakan atas tataran sistematis berikut ini. 


\begin{tabular}{|l|l|}
\hline bentuk antonim & contoh \\
\hline $\begin{array}{l}\text { antonim antara } \\
\text { kalimat }\end{array}$ & Dia sakit dan dia tidak sakit. \\
\hline antonim antara frase & $\begin{array}{l}\text { secara teratur dan secara tidak } \\
\text { teratur }\end{array}$ \\
\hline antonim antara kata & mustahil dan mungkin \\
\hline $\begin{array}{l}\text { antonim antara } \\
\text { morfem }\end{array}$ & prasarjana dan pascasarjana \\
\hline
\end{tabular}

Antonim diperlukan untuk menegaskan sesuatu dengan menyangkal atau mempertentangkan, contoh besar dan kecil, membeli dan menjual, atas dan bawah. Selain itu, kata yang berantonim dapat digabungkan sehingga melahirkan bentuk kata majemuk yang dapat menyemarakkan kalimat.

Contoh,

\begin{tabular}{|c|c|}
\hline $\begin{array}{l}\text { atas bawah bongkar } \\
\text { pasang jiwa raga jual } \\
\text { beli kawin cerai }\end{array}$ & $\begin{array}{l}\text { luar dalam maju } \\
\text { mundur mau tak } \\
\text { mau plus minus } \\
\text { utang piutang }\end{array}$ \\
\hline
\end{tabular}

Istilah berhomonim atau homonim terjadi jika dua kata mempunyai bentuk (tulisan) dan lafalnya sama, tetapi maknanya berbeda. Homonim dalam bahasa Indonesia hanya terjadi dalam bentuk tataran pada tingkat kata. Selain itu, homonim juga dapat dipahami satu kata yang mengandung beberapa makna disebut kata yang berhomonim atau kata yang homonim. Misalnya, kata buku dapat bermakna sendi (pada tulang, bambu, dan tebu), dapat pula bermakna kertas tulis yang dijilid (buku tulis, atau buku bacaan). Begitu pula kata bisa dapat bermakna racun atau dapat atau boleh.

Contoh :

(1) Saya membeli beberapa buah buku tulis. 
(2) Buku tulang-tulangku terasa nyeri.

Di samping homonim, ada pula yang disebut homofon dan homograf. Homofon adalah kata- kata yang sama lafalnya, tetapi berbeda ejaannya.

Misalnya, kata bang dan bank, sangsi dan sanksi.

Contoh :

(9) "Bagaimana bang, setujukah ?" Tanya istrinya.

(bang singkatan dari abang semakna dengan kakak, yaitu kakak laki- laki)

(10) Untuk menarik nasabah, beberapa bank mengadakan undian tabungan.

(bank, lembaga keuangan yang usaha pokoknya memberikan kredit dan jasa dalam lalu lintas pembayaran dan pengedaran uang)

Homograf adalah kata-kata yang sama ejaannya, tetapi berbeda lafalnya. Misalnya, kata teras (dengan e pepet) bermakna bagian atau bagian utama, seperti pada teras kayu dan pegawai teras, dan kata teras (dengan e taling) bermakna anjungan atau kaki lima, seperti pada teras rumah dan teras toko.

Contoh :

(11) Ayahnya adalah pegawai teras kantor gubernur.

(12) Pada waktu malam mulai larut, tampak beberapa orang tuna wisma tidur di teras toko.

Istilah hiponim terjadi jika makna suatu ungkapan merupakan bagian dari makna ungkapan yang lainnya. Misalnya, merah hiponim dari berwarna. Hiponim hanya berlaku satu arah dan kebalikan dari itu disebut hipernim, misalnya berwarna hipernim terhadap merah.

\section{Kata Konkret dan Kata Abstrak}

Kata-kata yang tergolong kata konkret adalah katakata yang berupa objek yang nyata, dapat dilihat, didengar, 
diraba, dan dirasa. Kata-kata konkret dapat dilihat pada kata orang, pohon, kucing, awan, makanan, dan minuman.

Kata abstrak adalah kata-kata yang berupa konsep. Kata-kata abstrak dalam bahasa Indonesia pada umumnya adalah kata-kata bentukan dengan konfiks peng-/ -an dan ke-/ -an, seperti pada kata-kata perdamaian, penyesalan, kecerdasan ketahanan nasional, di samping kata-kata seperti demokrasi dan aspirasi.

(13) Saya melihat seekor kucing memanjat pohon.

(14) Perdamaian yang merata di seluruh jagat raya ini masih tetap merupakan impian.

Kata -kata konkret dan kata-kata abstrak sama penting dalam penggunaan sesuai dengan kebutuhan.

\section{Kata Umum dan Kata Khusus}

Kata-kata yang tergolong kata umum dibedakan dari kata-kata yang tergolong kata khusus berdasarkan ruang lingkupnya. Makin luas ruang lingkup suatu kata makin umum sifatnya, sebaliknya makin sempit ruang lingkupnya makin khusus sifatnya. Kata-kata umum termasuk kata yang mempunyai hubungan luas, sedangkan kata-kata khusus mempunyai hubungan sempit, terbatas, bahkan khusus atau unik.

Bandingkan :

\section{kata umum}

pemimpin

runcing

memasak kata khusus

direktur

tajam mancung

menanak

Kata runcing dapat digunakan untuk menyebut sifat semua benda yang makin ke ujung makin kecil dan tajam, sedangkan kata mancung hanya digunakan secara khusus untuk hidung yang runcing. Demikian juga kata memasak digunakan untuk menyatakan pekerjaan masak-memasak 
secara umum, sedangkan menanak hanya khusus untuk menanak nasi.

\section{Kata Populer dan Kata Kajian}

Kata-kata yang tergolong kata populer adalah kata yang populer atau terkenal di kalangan masyarakat atau katakata yang banyak digunakan dalam berkomunikasi pada berbagai lapisan masyarakat. Sebaliknya, kata kajian adalah kata-kata yang digunakan secara terbatas pada kesempatan tertentu berupa kata atau istilah yang digunakan oleh golongan ilmuwan dalam pembicaraan tulisan ilmiah.

\section{kata populer}

isi

sejajar

bahagian unsur kata kajian

volume

paralel

suku cadang

\section{Kata Baku dan Tidak Baku}

Tuturan dan tulisan resmi harus menggunakan katakata baku, yaitu kata-kata yang telah resmi dan standar dalam penggunaannya. Kata-kata baku ada yang berasal dari bahasa Indonesia, ada juga yang berasal dari bahasa daerah dan bahasa asing yang telah disesuaikan dengan ejaan bahasa Indonesia yang resmi. Sebaliknya, kata-kata tidak baku, yaitu kata-kata yang belum berterima secara resmi atau kata-kata yang tidak mengikuti kaidah yang berlaku dalam bahasa Indonesia. Kata-kata tidak baku dapat berupa :

(1) kata-kata dari dialek-dialek bahasa Indonesia yang ada,

(2) kata-kata serapan bahasa daerah yang belum berterima,

(3) kata-kata bahasa asing yang tidak memenuhi persyaratan ejaan dalam bahasa Indonesia,

(4) kata-kata bahasa Indonesia yang dieja sebagai bahasa asing, dan 
(5) kata-kata bentukan yang tidak menuruti kaidah yang berlaku.

\section{kata baku}

perbaiki

beri tahu

\section{kata tidak baku}

bikin baik

kasih tahu

\section{Kata Mubazir}

Kata mubazir adalah kata-kata bersinonim atau katakata yang sama maknanya dan digunakan bersama-sama sekaligus sehingga menjadi mubazir, yaitu menjadi berlebihlebihan. Penggunaan kata mubazir itu dalam tuturan atau tulisan sebaiknya dihindari karena menimbulkan makna yang berlebihan. Hal seperti itu terlihat antara lain pada pemakaian kata-kata sejak dan dari, demi dan untuk, agar dan supaya, sebab dan karena, amat sangat dan sekali. adalah merupakan, namun demikian.

\section{Kata Mirip}

Kata-kata yang tergolong kata mirip adalah kata-kata yang tampak mirip dari segi bentuknya atau kata-kata yang rasanya mirip dari segi maknanya. Kata suatu dan sesuatu, sekali-sekali dan sekali-sekali, sedang dan sedangkan termasuk kata-kata memunyai kemiripan bentuk, sedangkan kata-kata seperti tiap-tiap dan masing-masing, jam dan pukul, dari dan daripada termasuk kata yang memunyai kemiripan makna. Kata-kata tersebut sering dikacaukan penggunaannya sehingga melahirkan kalimat yang tidak tepat, tidak baku, dan tidak efektif.

\begin{tabular}{|l|l|}
\hline \multicolumn{2}{|l|}{ kata-kata yang hampir mirip dalam ejaan } \\
\hline $\begin{array}{l}\text { intensif interferensi } \\
\text { karton preposisi } \\
\text { korporasi }\end{array}$ & $\begin{array}{l}\text { insentif inferensi } \\
\text { kartun proposisi } \\
\text { koperasi }\end{array}$ \\
\hline
\end{tabular}


Contoh:

a. Tinggallah dulu di sini, saya akan membicarakan sesuatu hal denganmu. (salah)

b. Tinggallah dulu di sini, saya akan membicarakan sesuatu denganmu. (benar) pilih sesuatu atau suatu hal

c. Pelajaran pertama berlangsung pada pukul 07.30 sampai dengan 09.30. (kata pukul digunakan menunjukkan waktu)

d. Pelajaran pertama berlangsung selama dua jam. (kata jam digunakan menunjukkan jangka waktu)

\section{Pasangan Idiomatis}

Berdasarkan kaidah bahasa maka dalam bahasa Indonesia terdapat pilihan kata yang merupakan kata berpasangan tetap atau ungkapan idiomatis. Kata tersebut selalu muncul bersamaan, tidak dapat dipisahkan antara satu dengan yang lainnya.

Contoh :

\begin{tabular}{|l|l|}
\hline \multicolumn{2}{|l|}{ bentuk kata pasangan idiomatis } \\
\hline sesuai dengan .... terdiri & bergantung pada ... \\
atas ... terbuat dari ... & berbeda dengan ... \\
terjadi dari . . & berbeda dari ... \\
sehubungan dengan ... & berharap akan ... \\
berbicara tentang ... & bertemu dengan ... \\
disebabkan oleh ... & sejalan dengan ... \\
& berkenaan dengan ... \\
\hline
\end{tabular}

\section{B. Penggunaan Pilihan Kata (Diksi)}

1. Ketepatan diksi

Agar pemilihan kata benar-benar tepat, seseorang pengguna bahasa diharapkan dapat memahami syarat-syarat dalam pemilihan kata. Syarat yang dimaksud di antaranya adalah ketepatan diksi dan kesesuain diksi. Syarat ketepatan diksi adalah sebagai berikut : 
(1) membedakan secara tepat antara kata bermakna konotasi dan denotasi,

(2) membedakan secara cermat terhadap kata yang hampir sama maknanya,

(3) membedakan kata-kata yang mirip atau hampir mirip ejaannya,

(4) mewaspadai akhiran asing yang kurang tepat,

(5) memahami kata yang tergolong kata umum dan kata khusus,

(6) memperhatikan perubahan makna yang terjadi pada kata-kata yang sudah dikenal.

Persyaratan kesesuaian diksi adalah hal yang sangat penting dalam pemilihan kata, agar kata-kata yang dipergunakan tidak mengganggu suasana dan tidak akan menimbulkan ketegangan antara penulis dan pembaca atau antara pembicara dan pendengar. Persyaratan yang dimaksud adalah :

(1) hindari kemungkinan penggunaan kata yang tidak baku pada situasi formal,

(2) gunakan kata-kata ilmiah dalam situasi yang khusus saja, dalam situasi yang umum hendaknya penulis atau pembicara menggunakan kata-kata populer,

(3) dalam penulisan, jangan menggunakan kata percakapan, kecuali saat menulis kutipan untuk menunjang isi tulisan,

(4) hindari penggunaan ungkapan yang sudah usang,

(5) hindari kata-kata yang mubazir,

(6) hindari penggunaan bahasa atau dialek kedaerahan dalam tulisan pembaca umum, kecuali istilah dalam bahasa daerah yang telah diserap ke dalam bahasa Indonesia.

2. Kesalahan Diksi 
Kesalahan diksi meliputi kesalahan kalimat yang disebabkan oleh kesalahan pemakaian kata. Berikut ini akan dikemukakan beberapa contoh penggunaan diksi yang tidak tepat penggunaannya dalam kalimat.

(1) Pemakaian kata tidak tepat di antaranya ada beberpa, yaitu kata dari atau daripada sering digunakan tidak tepat, seperti dalam contoh berikut.

Hasil daripada penjualan saham akan digunakan untuk memperluas bidang usaha. Penggunaan kata daripada pada kalimat di atas tidak tepat karena kata daripada hanya dapat dipakai membandingkan antara dua buah objek. Jadi, kata yang tepat dalam pemakaian kalimat tersebut adalah kata dari yang menyatakan asal.

(2) Pemakaian kata berpasangan, yaitu ada sejumlah kata yang pemakaiannya berpasangan disebut konjungsi korelatifa, seperti di bawah ini.

\begin{tabular}{|c|c|}
\hline pasangan yang salah & pasangan yang benar \\
\hline $\begin{array}{l}\text { antara } \ldots \text {. dengan } \ldots \text {. tidak } \\
\ldots \text { melainkan } \ldots \text {. baik ... } \\
\text { ataupun ... bukan ... } \\
\text { tetapi . . . }\end{array}$ & $\begin{array}{l}\text { antara } \ldots \text {. dan . . . tidak } \\
\ldots \text { tetapi ... baik ... } \\
\text { maupun ... bukan ... } \\
\text { melainkan . . . }\end{array}$ \\
\hline
\end{tabular}

Dalam contoh berikut dikemukakan pemakaian kata berpasangan secara tidak tepat.

Contoh :

Baik pedagang ataupun konsumen masih menunggu kepastian harga sehingga tidak terjadi transaksi. (salah)

Baik pedang maupun konsumen masih menunggu kepastian harga sehingga tidak terjadi transaksi. (benar)

(3) Pemakaian dua kata, yaitu dalam kenyataan terdapat pemakaian dua kata yang bermakna dan berfungsi 
sama. Kata-kata yang sering digunakan secara serentak, bahkan pada posisi yang sama, seperti: ialah adalah merupakan, agar supaya, demi untuk, seperti contoh misalnya, atau daftar nama-nama.

Contoh :

Peningkatan mutu penggunaan bahasa Indonesia adalah merupakan kewajiban kita. (salah)

Peningkatan mutu penggunaan bahasa Indonesia adalah kewajiban kita. (benar)

(4) Kelangsungan pilihan kata dapat berlangsung dengan baik jika maksud atau pikiran penulis atau pembaca tersampaikan secara tepat dan mudah dimengerti. Kelangsungan pilihan kata dapat terganggu bila seorang pembicara atau pengarang menggunakan terlalu banyak kata untuk maksud yang dapat diungkapkan secara singkat. Oleh karena itu, pemilihan kata dapat berlangsung dengan baik, ada beberapa hal yang harus diperhatikan oleh penulis, yaitu :

(1) Menghindari kata-kata yang tidak menambah kejelasan makna kata.

(2) Menghindari penggunaan beberapa kata yang bermakna sama.

(3) Menghindari penggunaan istilah baru karena dapat menimbulkan kebingungan bagi pembaca atau pendengar.

Dalam proses perkembangan bahasa kata dapat mengalami perubahan. Perubahan itu terjadi karena perbedaan tempat pemakaian, perbedaan waktu pemakaian, dan kehendak untuk memberi makna baru. Hal tersebut akan memengaruhi pilihan kata baik dalam penulisan maupun penuturan. Di antara perubahan makna yang penting adalah sebagai berikut : 
1. Meluas, yaitu jika cakupan makna sekarang lebih luas dari makna yang lama. Misalnya, kata putraputri yang dahulu hanya dipakai untuk anak-anak raja, sekarang dipakai untuk menyebut semua anak laki-laki dan perempuan.

2. Menyempit, yaitu jika cakupan makna dahulu lebih luas dari makna yang sekarang. Misalnya, kata sarjana dahulu dipakai untuk semua cendekiawan, sekarang hanya khusus untuk gelar akademik.

3. Amelioratif, yaitu perubahan makna yang mengakibatkan makna baru dirasakan lebih tinggi atau lebih baik nilainya dari makna lama. Misalnya, kata istri dan nyonya dirasakan lebih baik daripada kata bini.

4. Peyoratif, yaitu perubahan makan yang mengakibatkan makna baru dirasakan lebih rendah nilainya dari makna lama (kebalikan dari amelioratif). Misalnya, kata oknum dan gerombolan yang dianggap baik pada zaman lampau sekarang maknanya menjadi tidak baik.

5. Sinestesia, yaitu perubahan makna yang terjadi karena pertukaran tanggapan dua indera yang berlainan. Misalnya, kata kata-katanya manis. Manis sebenarnya tanggapan indera perasa, tetapi dipakai untuk indera pendengar.

6. Asosiasi, yaitu perubahan makna yang terjadi karena persamaan sifat. Misalnya, kata amplop yang berarti kertas pembungkus surat, juga sering digunakan sebagai pembungkus uang, berdasarkan persamaan tersebut dipakai untuk pengertian memberi sogokan. Contoh, Beri dia amplop agar urusan cepat beres. 


\section{BAB IV \\ PEMBENTUKAN DAN PERLUASAN \\ KALIMAT}

\section{A. Pendahuluan}

ahasa adalah sarana berpikir baik untuk
menyampaikan pesan kepada orang lain
maupun untuk menerima pesan dari orang lain.

Pikiran yang disampaikan dalam pembicaraan atau tulisan diungkapkan melalui rangkaian kata yang terpilih dan tersusun menurut kaidah tertentu. Bahasa merupakan simbol yang bermakna terdiri atas satuan-satuan tertentu yang secara fungsional saling berhubungan sebagai satu sistem. Satuan terkecil yang mengandung makna berupa kata dan frasa, sedangkan satuan yang lebih besar yang mengandung pikiran yang utuh dapat berupa kalimat. Penggunaan bahasa sebagai sarana berpikir dan berkomunikasi sangat ditentukan oleh penguasaan kaidah kalimat yang didukung oleh kosakata yang memadai.

\section{B. Pengertian Kalimat}

Kalimat sebagai satuan bahasa lebih besar daripada kata atau frasa umumnya muncul dalam tulisan atau pembicaraan berupa rangkaian kata yang menyatakan pikiran tertentu yang secara relatif dapat berdiri sendiri, dan intonasinya menunjukkan batas antara sesamanya. Itulah yang disebut kalimat. Setiap kalimat yang muncul dalam tulisan atau pembicaraan masing-masing menyatakan pikiran yang terbatas, tetapi tetap utuh baik secara tersurat maupun tersirat.

Kalimat adalah satuan bahasa terkecil yang merupakan kesatuan pikiran. Dalam bahasa lisan kalimat diawali dan diakhiri dengan kesenyapan, dalam bahasa tulis diawali 
dengan huruf kapital dan diakhiri dengan tanda titik, tanda seru, atau tanda tanya. Kalimat disusun berdasarkan unsurunsur yang berupa kata, frase, atau klausa. Jika disusun berdasarkan pengertian di atas, unsur-unsur tersebut mempunyai fungsi dan pengertian tertentu yang disebut bagian kalimat. Ada bagian kalimat yang tidak dapat dihilangkan disebut inti kalimat (subjek dan predikat), sedangkan bagian yang dapat dihilangkan bukan unsur inti kalimat (objek, keterangan, dan pelengkap). Bagian inti dapat membentuk kalimat dasar dan bagian bukan inti dapat membentuk kalimat luas.

Pikiran yang utuh pada setiap kalimat diungkapkan pada dua bagian, yaitu subjek dan predikat. Subjek sebagai bagian yang menjadi pokok pembicaraan dalam kalimat dijelaskan maknanya oleh predikat.

Contoh :

(1) Anak itu cerdas.

Pikiran yang utuh pada contoh (1) dapat diketahui dengan adanya kata cerdas yang merupakan jawaban atas pertanyaan mengapa/ bagaimana anak itu. Unsur yang merupakan jawaban atas pertanyaan mengapa/ bagaimana, berfungsi sebagai predikat. Unsur anak itu yang merupakan jawaban atas pertanyaan siapa yang cerdas berfungsi sebagai subjek.

Unsur subjek dan predikat dapat dipertukarkan posisinya, tanpa merusak keutuhan pikiran dari kalimat tersebut. Perhatikan contoh berikut :

(1a) Cerdas anak itu.

Berdasarkan uraian di atas, dapat diketahui ciri-ciri kalimat sebagai berikut :

(1) Dari segi makna, sebuah kalimat harus mengandung pikiran yang utuh, sedangkan dari segi struktur, kalimat 
sekurang-kurangnya mengandung unsur subjek dan predikat.

(2) Unsur-unsur yang berupa subjek predikat posisinya dapat dipertukarkan menjadi predikat subjek.

(3) Subjek dapat diketahui dari jawaban atas pertanyaan apa/siapa, sedangkan predikat dapat diketahui dari jawaban atas pertanyaan bagaimana/ mengapa.

\section{Bagian-bagian Kalimat}

Dalam uraian terdahulu telah disebutkan bahwa kalimat adalah rangkaian kata yang menyatakan pikiran tertentu yang secara relatif dapat berdiri sendiri, dan intonasinya menunjukkan batas antara sesama kalimat. Selanjutnya, kata atau kelompok kata yang dipakai untuk membentuk kalimat menduduki fungsi-fungsi tertentu dalam struktur kalimat. Sebagai unsur terintegrasi ke dalam suatu struktur, kata-kata tersebut merupakan unsur kalimat.

Bagian inti yang harus terdapat pada kalimat adalah subjek (S) dan predikat (P). Bagian inti kalimat adalah bagian yang tak dapat dihilangkan dalam struktur kalimat. Subjek kalimat berfungsi sebagai inti pembicaraan, sedangkan predikat berfungsi sebagai penjelasan terhadap subjek, yang dapat dilengkapi dengan objek $(\mathrm{O})$ atau keterangan $(\mathrm{K})$.

\section{Subjek dan Predikat}

Setiap kalimat sebagai bentuk pernyataan pikiran mempunyai subjek dan predikat, baik yang dinyatakan secara tersurat maupun yang dinyatakan secara tersirat. Subjek sebagai inti pembicaraan barulah menyatakan pikiran jika dijelaskan oleh predikat. Hubungan antara subjek dan predikat dalam kalimat turut menentukan isi pikiran yang dimaksud. Kata-kata yang digaris bawahi pada contoh berikut berfungsi sebagai subjek (S) dan predikat (P) kalimat. 
Contoh :

(2) Saya sebaiknya beristirahat sejenak.

$\mathrm{S}$

$P$

(3) Perusahaannya makin berkembang akhir-akhir ini.

$S$

$P$

(4) Engkau belajar dengan tekun.

S $P$

Isi pikiran yang terdapat pada kalimat tercermin pada hubungan antara subjek dan predikat. Tanpa adanya subjek, pokok pembicaraan dalam setiap kalimat menjadi tidak jelas. Sebaliknya, tanpa adanya predikat, keadaan subjek atau situasi yang meliputi subjek tidak jelas.

Bagaimana saya ? beristirahat sejenak (sebaiknya)

Siapa yang sebaiknya beristirahat sejenak ? saya

\section{Objek dan Keterangan}

Objek dan keterangan adalah dua bagian kalimat yang sering muncul dalam kalimat untuk melengkapi predikat. Hubungan antara objek $(O)$ dan predikat $(P)$ ternyata lebih erat daripada hubungan antara keterangan $(\mathrm{K})$ dan predikat Contoh :

(5) la membaca buku itu beberapa kali. $\begin{array}{llll}S & P & O & K\end{array}$

(6) Kami merayakan hari ulang tahunnya kemarin. $S \quad P$

O $\mathrm{K}$

Objek pada kalimat (6) buku itu, kalimat (7) hari ulang tahunnya dan pada kalimat (8) orang tuanya terlihat dengan jelas hubungan yang erat dengan predikat.

Keterangan yang menyertai predikat kalimat bervariasi sesuai dengan fungsinya untuk melengkapi predikat. Hubungan yang agak longgar antara keterangan dan predikat memungkinkan penempatan keterangan dalam struktur 
kalimat. Jenis-jenis keterangan yang bermacam-macam itu dapat dilihat pada contoh berikut :

(9) la berdiri di tempat itu sejak tadi.

$\mathrm{K}$ (tempat)

(10) Ujian berlangsung selama dua jam.

$\mathrm{K}$ (waktu)

\section{Kalimat Tunggal}

Kalimat tunggal adalah kalimat yang hanya menyatakan satu pokok pembicaraan yang dinyatakan pada subjek (S) kalimat. Penjelasan terhadap subjek tersebut dinyatakan pada predikat $(P)$. Jika predikat kalimat menggunakan kata kerja aktif transitif, kalimat tersebut dilengkapi dengan objek tertentu. Bagian lain yang berfungsi memberikan penjelasan tambahan terhadap predikat kalimat adalah keterangan. Pola umum kalimat tunggal tersebut juga sederhana, yaitu $\mathrm{S} / \mathrm{P}, \mathrm{S} / \mathrm{P} / \mathrm{O}, \mathrm{S} / \mathrm{P} / \mathrm{K}, \mathrm{S} / \mathrm{P} / \mathrm{O} / \mathrm{K}$, yang dapat diubah menjadi variasi tertentu melalui pertukaran bagianbagiannya.

(11) Usahanya berhasil.

$(\mathrm{S} / \mathrm{P})$

(12) Petani itu menyiangi sawahnya.

$(\mathrm{S} / \mathrm{P} / \mathrm{O})$

(13) Mahasiswa itu belajar dengan tekun.

$(\mathrm{S} / \mathrm{P} / \mathrm{K})$

(14) Kami memanfaatkan peluang itu dengan baik.

(S/P/O/K)

Hubungan bagian kalimat yang satu dengan bagian kalimat yang lain tidaklah sama. Predikat kalimat mempunyai hubungan yang erat dengan objeknya sehingga pengubahan pola kalimat dengan variasi lain dalam kalimat aktif harus tetap mempertahankan posisi objek di belakang $\mathrm{P}(\mathrm{P} / \mathrm{O})$. Bagian keterangan ternyata mempunyai hubungan yang longgar 
dengan predikat sehingga berpeluang untuk ditempatkan pada berbagai posisi tanpa merusak makna kalimat.

Kepaduan hubungan bagian-bagian kalimat akan memperjelas kalimat sebagai pernyataan pikiran. Isi pikiran yang dinyatakan pada setiap kalimat dapat berupa berita (kalimat berita). Pertanyaan (kalimat tanya), perintah atau larangan (kalimat perintah), dan seruan (kalimat seru). Jenis kalimat yang dapat dipakai dalam penyusunan karya ilmiah adalah kalimat berita yang menyatakan suatu peristiwa atau keadaan. Isinya bersifat pernyataan (deklarasi) sehingga dapat dinilai benar atau salah.

Contoh :

(15) Kegiatan penelitian yang menunjang pengembangan ilmu dan teknologi perlu mendapat perhatian. (kalimat berita)

(16) Di mana kepentingan kita diletakkan ? (kalimat tanya)

(17) Kerjakanlah tugas itu dengan cermat ! (kalimat perintah)

(18) Alangkah mulianya hati orang itu !

(kalimat seru)

Penggabungan dan perluasan kalimat-kalimat tunggal sering dilakukan dalam penyusunan karya tulis. Beberapa kalimat tunggal yang gagasannya berkaitan kemudian dipadukan menjadi satu kalimat majemuk untuk mempertegas kaitan gagasan yang terkandung di dalamnya. Cara menempatkan gagasan yang saling berkaitan dalam struktur kalimat majemuk menentukan hubungan gagasan-gagasan tersebut. Selanjutnya, dalam kalimat majemuk, bagian kalimat tunggal yang sama umumnya cukup dinyatakan satu kali (pelepasan bagian kalimat). 


\section{E. Kalimat Majemuk Setara}

Kalimat majemuk setara adalah kalimat majemuk yang terbentuk dari penggabungan beberapa kalimat tunggal yang setara kedudukannya dan menyatakan peristiwa yang terjadi secara berturut-turut atau dalam waktu yang bersamaan. Hubungan koordinatif antara bagian kalimat yang satu dan bagian kalimat yang lain yang setara itu akan terlihat pada penggunaan kata sambung (kata penghubung) sebagai koordinator dalam struktur kalimat majemuk. Kalimat majemuk setara mempunyai ciri (1) dibentuk dari dua atau lebih kalimat tunggal dan (2) kedudukan tiap kalimat sederajad. Karena kalimat majemuk merupakan gabungan kalimat, lebih tepat jika kalimat yang digabung itu disebut dengan istilah klausa. Penggabungan kalimat-kalimat tunggal menjadi kalimat majemuk dapat menunjukkan beberapa jenis hubungan dan menjalankan beberapa fungsi yang sangat tergantung pada kata penghubung di antaranya adalah penjumlahan, pertentangan, pemilihan, perurutan, dan penguatan. Untuk lebih jelasnya dapat dibaca dalam tabel di bawah ini.

\begin{tabular}{|c|c|c|}
\hline $\begin{array}{l}\text { Jenis } \\
\text { Hubungan }\end{array}$ & Fungsi & $\begin{array}{l}\text { Kata Penghubung } \\
\text { (Konjungsi) }\end{array}$ \\
\hline $\begin{array}{l}\text { penjumlahan } \\
\text { pertentangan } \\
\text { pemilihan } \\
\text { perurutan } \\
\text { penguatan }\end{array}$ & $\begin{array}{l}\text { menyatakan } \\
\text { penjumlahan atau } \\
\text { gabungan kegiatan, } \\
\text { keadaan, peristiwa, } \\
\text { dan proses } \\
\text { menyatakan apa } \\
\text { yang dinyatakan } \\
\text { dalam klausa } \\
\text { pertama } \\
\text { bertentangan }\end{array}$ & $\begin{array}{l}\text { dan, serta, baik, } \\
\text { maupun, sesudah } \\
\text { itu tetapi, } \\
\text { sedangkan, } \\
\text { bukannya, } \\
\text { melainkan atau } \\
\text { lalu, kemudian } \\
\text { malah(an), } \\
\text { bahkan, apalagi, } \\
\text { lagipula, }\end{array}$ \\
\hline
\end{tabular}




\begin{tabular}{|l|l|l|}
\hline & $\begin{array}{l}\text { dengan klausa } \\
\text { kedua menyatakan } \\
\text { pilihan di antara dua } \\
\text { kemungkinan } \\
\text { menyatakan }\end{array}$ & \\
kejadian yang & \\
berurutan & \\
menyatakan & \\
penguatan atau & \\
penekanan & \\
terhadap kejadian & \\
atau peristiwa & \\
\hline
\end{tabular}

(18) la menyadari kesalahannya dan berusaha memperbaiki kesalahannya.

(19) Tingkah lakunya yang buruk itu tidak saja merugikan dirinya, tetapi juga merugikan keluarganya.

(20) Kita menyelesaikan pekerjaan itu dengan segera atau menyerahkan kepada orang lain.

\section{F. Kalimat Majemuk Bertingkat}

Kalimat majemuk bertingkat adalah kalimat yang terbentuk dari sebuah kalimat tunggal yang salah satu bagiannya mengalami perluasan atau penggantian dengan kalimat lain. Hubungan bagian kalimat yang satu dengan bagian kalimat yang lain dalam suatu struktur kalimat majemuk tidak sama atau bertingkat. Bagian yang lebih tinggi kedudukannya disebut induk kalimat (klausa utama), sedangkan bagian yang lebih rendah kedudukannya disebut anak kalimat (klausa sematan).

Hubungan antara induk kalimat dan anak kalimatnya bersifat subordinatif. Penggunaan kata sambung tertentu 
sebagai subordinator dalam perluasan kalimat tunggal menentukan hubungan induk kalimat dengan anak kalimat. Oleh karena itu, konjungtor yang menghubungkan antara klausa kalimat majemuk bertingkat berbeda dengan konjungtor pada kalimat majemuk setara. Dalam tabel di bawah dapat dilihat jenis hubungan antarklausa, konjungtor atau kata penghubung, dan fungsinya.

\begin{tabular}{|l|l|l|}
\hline $\begin{array}{l}\text { Jenis } \\
\text { Hubungan }\end{array}$ & Fungsi & $\begin{array}{l}\text { Kata Penghubung } \\
\text { (Konjungsi) }\end{array}$ \\
\hline waktu & & kyarat/ \\
pengandaian & menyatakan waktu & sejak, sedari, \\
tujuan & terjadinya peristiwa & semaktu, \\
konsesif & atau keadaan yang & setelah, sambil, \\
pembandingan & dinyatakan dalam & sehabis, sebelum, \\
penyebaban & klausa utama klausa & ketika, tatkala, \\
pengakibatan & bawahan menyatakan & hingga, sampai, \\
cara & syarat atau & selama, \\
kemiripan & pengandaian & jika(lau),seandainya, \\
penjelasan/ & terlaksananya apa yang & andaikata, \\
penegasan & disebut dalam klausa & asal(kan), kalau, \\
& utama klausa bawahan & apabila, bilamana, \\
& menyatakan suatu & manakala agar, \\
& tujuan atau harapan & supaya, untuk, biar \\
dari apa yang disebut & walau(pun),meski(p \\
& dalam klausa utama & un) sekalipun, \\
& klausa bawahan & biar(pun), kendati \\
& memuat pernyataan & (pun), sungguh(pun) \\
& yang tidak akan & seperti, bagaikan, \\
& mengubah apa yang & laksana, \\
& dinyatakan dalam & sebagaimana, dari- \\
& klausa utama & pada, alih-alih, \\
& memperlihatkan & ibarat \\
\hline
\end{tabular}




\begin{tabular}{|l|l|l|}
\hline $\begin{array}{l}\text { perbandingan antara } \\
\text { pernyataan pada klausa } \\
\text { utama dengan } \\
\text { pernyataan pada klausa } \\
\text { bawahan klausa }\end{array}$ & $\begin{array}{l}\text { karenaren } \\
\text { sehinga, sampai(- } \\
\text { sampai), maka } \\
\text { dengan, tanpa } \\
\text { bawahan menyatakan } \\
\text { seolah-olah, } \\
\text { seakan-akan } \\
\text { terjadinya sesuatu yang } \\
\text { dinyatakan dalam } \\
\text { klausa utama klausa } \\
\text { bawahan menyatakan } \\
\text { akibat dari apa yang } \\
\text { dinyatakan dalam } \\
\text { klausa utama klausa } \\
\text { bawahan menyatakan } \\
\text { cara pelaksanaan dan } \\
\text { alat dari apa yang } \\
\text { dinyatakan oleh klausa } \\
\text { utama klausa bawahan } \\
\text { menyatakan adanya } \\
\text { kenyataan yang mirip } \\
\text { dengan keadaan yang } \\
\text { sebenarnya klausa } \\
\text { bawahan menyatakan } \\
\text { penegasan atau } \\
\text { penjelasan terhadap } \\
\text { peristiwa yang } \\
\text { dinyatakan pada klausa } \\
\text { utama }\end{array}$ & \\
& \\
\hline
\end{tabular}

Contoh :

la datang di rumah kemarin. (kalimat tunggal) 
la datang di rumah ketika kami sedang merayakan hari ulang tahun adikku. (kalimat majemuk yang diperluas) (kemarin mengalami perluasan/ pergantian)

1. Peluasan kalimat melalui hubungan waktu dengan menggunakan kata sambung ketika, setelah, sewaktu, selama, sementara.

Contoh : la berhasil mengembangkan pabriknya setelah memperoleh pinjaman modal dari bank.

2. Perluasan kalimat melalui hubungan syarat dengan menggunakan kata sambung jika, kalau, jikalau, asal (kan), bila, manakala.

Contoh : Saya bekerja dengan tekun bila berhasil diterima sebagai pegawai di kantor itu.

a. Perluasan kalimat melalui hubungan pengandaian dengan menggunakan kata sambung seandainya dan sekiranya.

Contoh : Seandainya usul-usul yang diajukannya itu diterima oleh pengurus, tentu program kerja organisasi dapat terlaksana dengan baik.

b. Perluasan kalimat melalui hubungan tujuan dengan menggunakan kata sambung agar dan supaya

Contoh : Engkau harus belajar dengan sungguhsungguh agar dapat mencapai indeks prestasi yang tinggi.

c. Perluasan kalimat melalui hubungan perlawanan (konsesif) dengan menggunakan kata sambung meskipun, walaupun, sungguhpun, dan biarpun

Contoh : Meskipun hari hujan, anak itu pergi juga ke sekolah. 
d. Perluasan kalimat melalui hubungan pemiripan atau perbandingan dengan menggunakan kata sambung seperti, laksana, dan sebagaimana.

Contoh : Wajah gadis itu cantik dan menawan laksana bulan purnama.

e. Perluasan kalimat melalui hubungan sebab dengan menggunakan kata sambung sebab dan karena.

Contoh : Pekerja itu tidak dapat merampungkan pekerjaannya sebab seminggu ia sakit.

f. Perluasan kalimat melalui hubungan akibat dengan menggunakan kata sambung hingga, sehingga, dan sampai.

Contoh : Ayah bekerja terlalu keras sehingga jatuh sakit.

g. Perluasan kalimat melalui hubungan penjelasan atau penegasan dengan menggunakan kata sambung bahwa.

Contoh : la baru sadar bahwa pendidikan itu sangat penting bagi masa depan anak-anaknya.

h. Perluasan kalimat melalui hubungan cara atau alat dengan menggunakan kata sambung dengan.

Contoh : Polisi menyelidiki peristiwa kejahatan tersebut dengan menyamar sebagai buruh pabrik.

\section{G. Jenis Konjungsi}

Konjungsi atau kata penghubung dalam bahasa Indonesia terdiri atas konjungsi intrakalimat, yaitu konjungsi yang terletak di tengah kalimat, dan konjungsi antarkalimat, yaitu konjungsi yang terletak di awal kalimat. Jenis konjugsi ini menentukan perlu tidaknya disisipkan tanda baca koma di dalam kalimat. Konjungsi intrakalimat ada yang harus diikuti tanda koma, ada pula yang tidak. Sebaliknya, konjungsi antarkalimat harus diikuti tanda koma. 
Contoh :

\begin{tabular}{|c|c|}
\hline $\begin{array}{l}\text { Konjungsi intrakalimat yang } \\
\text { tidak didahului koma }\end{array}$ & $\begin{array}{l}\text { Konjungsi intrakalimat yang } \\
\text { didahului koma }\end{array}$ \\
\hline 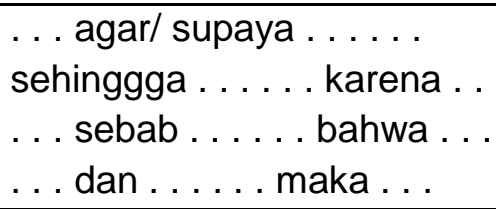 & 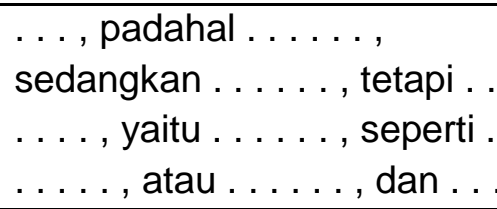 \\
\hline \multicolumn{2}{|c|}{$\begin{array}{l}\text { Catatan : kata konjungsi dan, atau dapat didahului tanda } \\
\text { koma jika suatu kalimat terdapat pemerian atau keterangan } \\
\text { yang beruntun }\end{array}$} \\
\hline
\end{tabular}

\begin{tabular}{|c|c|}
\hline konjungsi antarkalimat & \\
\hline 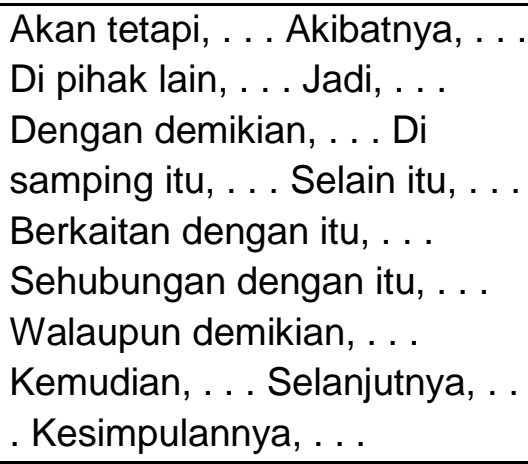 & $\begin{array}{l}\text { Kendatipun demikian, ... } \\
\text { Meskipun demikian, ... } \\
\text { Oleh karena itu, ... Oleh } \\
\text { sebab itu, ... Sebaliknya, } \\
\ldots \text {. Namun, . . Tambahan } \\
\text { lagi, ... Lagi pula, ... } \\
\text { Pertama, . . . Kedua, ... }\end{array}$ \\
\hline
\end{tabular}




\section{BAB V \\ PEMBENTUKAN PARAGRAF}

\section{A. Pendahuluan}

ikiran utama atau gagasan utama yang dikembangkan dalam tulisan disusun melalui seperangkat kalimat yang saling berhubungan dalam kesatuan yang lebih besar, yaitu paragraf atau alinea. Paragraf merupakan wadah pengembangan pikiran dalam tulisan, yang memberikan kesempatan bagi penulis untuk merinci pikirannya secara logis dan sistematis dalam seperangkat kalimat yang saling berhubungan secara fungsional. Penyusunan dan pengembangan pikiran dalam paragraf dapat membantu pengungkapan pikiran penulis secara bertahap dan tertib sehingga maksud penulis mudah dipahami dan diterima oleh pembaca.

\section{B. Pengertian Paragraf}

Paragraf adalah satu kesatuan pikiran, suatu kesatuan yang lebih luas daripada kalimat. la merupakan himpunan dari kalimat-kalimat yang bertalian dalam suatu rangkaian untuk menjelaskan sebuah pikiran utama. Melalui paragraf itu gagasan menjadi jelas oleh uraian tambahan, yang tujuannya menonjolkan pikiran utama secara lebih jelas. Setiap paragraf hanya boleh mengandung satu pikiran utama atau gagasan utama secara jelas.

Dalam upaya menghimpun beberapa kalimat menjadi paragraf, yang perlu diperhatikan adalah kesatuan dan kepaduan. Kesatuan berarti seluruh kalimat dalam paragraf membicarakan satu gagasan. Kepaduan berarti seluruh kalimat dalam paragraf itu kompak, saling berkaitan mendukung gagasan tunggal dalam paragraf. Apabila dalam suatu paragraf terdapat lebih dari satu gagasan berarti paragraf itu 
tidak tepat dan harus dipecah ke dalam beberapa paragraf. Jadi, setiap paragraf hanya boleh mengandung satu pikiran utama atau gagasan utama.

Contoh (1)

Sampah yang kita buang setiap hari sebenarnya dapat digolongkan menjadi dua macam, yaitu sampah organik dan sampah anorganik. Sampah organik adalah sampah yang mudah membusuk, seperti sisa makanan dan daun-daunan yang umumnya basah. Sampah anorganik adalah sampah yang sulit atau yang tidak dapat membusuk, contohnya plastik, kaca, logam, kain, dan karet. Kedua jenis sampah tersebut dapat memberikan manfaat bagi kehidupan baik jenis sampah organik maupun sampah anorganik jika diolah dengan baik.

Contoh paragraf di atas terdiri atas empat kalimat. Setelah membaca keseluruhan paragraf tersebut, terasa bahwa semua kalimat membicarakan satu ide atau satu gagasan, yaitu sampah organik dan anorganik. Ide tersebut diungkapkan melalui empat kalimat. Ide tersebut lebih luas jika dibandingkan dengan ide yang ada dalam sebuah kalimat.

\section{Struktur Paragraf}

Berdasarkan fungsinya, kalimat yang membangun paragraf pada dasarnya terdiri atas dua macam, yaitu (1) kalimat topik atau kalimat pokok dan (2) kalimat penjelas atau pendukung. Kalimat topik adalah kalimat yang berisi ide pokok atau ide utama paragraf, sedangkan kalimat penjelas atau pendukung adalah kalimat yang berfungsi menjelaskan atau mendukung ide utama paragraf. Ciri kalimat topik dan kalimat penjelas adalah sebagai berikut.

Ciri kalimat topik : 
(1) mengandung permasalahan yang potensial untuk dirinci dan diuraikan lebih lanjut,

(2) merupakan kalimat lengkap yang dapat berdiri sendiri,

(3) memunyai arti yang cukup jelas tanpa harus dihubungkan dengan kalimat lain,

(4) dapat dibentuk tanpa bantuan kata sambung dan frase transisi.

Ciri kalimat penjelas :

(1) sering merupakan kalimat yang tidak dapat berdiri sendiri (dari segi arti),

(2) arti kalimat ini kadang-kadang baru jelas setelah dihubungkan dengan kalimat lain dalam satu paragraf,

(3) pembentukannya sering memerlukan pembentukan kata sambung dan frase transisi,

(4) isinya berupa rincian, keterangan, contoh, dan data tambahan lain yang bersifat mendukung kalimat topik.

\section{Tujuan Pembentukan Paragraf}

Apabila kita pernah membaca sebuah tulisan yang tidak tersusun atas kesatuan paragraf, kita akan sulit memahami isinya. Kita dituntut untuk memeriksa lebih cermat pikiran penulis dari awal sampai akhir secara menyeluruh tanpa petunjuk yang jelas. Hal ini tidak akan terjadi pada tulisan yang tersusun atas serangkaian paragraf yang baik. Setelah kita membaca sebuah paragraf, kita dapat berhenti sebentar dan berkonsentrasi terhadap pikiran utama yang terkandung dalam paragraf tersebut sebelum melangkah pada paragraf berikutnya.

Ada dua tujuan utama pembentukan paragraf. Pertama, pembentukan paragraf bertujuan memudahkan 
pengertian dan pemahaman dengan memisahkan pikiran utama yang satu dari utama pikiran yang lain. Oleh karena itu, paragraf hanya dapat memuat satu pikiran utama. Apabila terdapat dua pikiran utama, paragraf tersebut harus dipecah menjadi dua atau lebih. Kedua, pembentukan paragraf bertujuan memisahkan dan menegaskan perhentian secara wajar dan formal untuk memungkinkan kita berhenti lebih lama daripada perhentian pada akhir kalimat. Dengan perhentian yang lebih lama tersebut, kosentrasi terhadap pikiran utama pada setiap paragraf lebih terarah.

Contoh (2)

Bidang pendidikan merupakan wadah dan lingkunga formal yang harus menerima anak didik dari semua suku bangsa Indonesia. Oleh karena itu, sesuai dengan pokok kebijaksanaan pendidikan dan kebudayaan dan gbhn maka kedudukan dan fungsi bahasa indonesia dalam hubungannya dengan pendidikan nasional adalah (1) sebagai mata pelajaran dasar dan pokok dan (2) sebagai bahasa pengantar di semua jenjang sekolah. Bahasa daerah dapat dipakai untuk membantu bahasa Indonesia sebagai bahasa pengantar di kelas satu sampai kelas tiga SD di daerah-daerah yang masih memerlukannya. Di samping itu, bahasa daerah dapat pula diajarkan sebagai satu mata pelajaran. Selain itu, juga bahasa daerah dianggap sebagai salah satu media pengembangan kebudayaan.

Paragraf di atas berisi dua pikiran utama, yaitu (1) kedudukan dan fungsi bahasa Indonesia dan (2) kedudukan dan fungsi bahasa daerah. Oleh karena itu, paragraf tersebut haruslah dijadikan dua buah, seperti yang terlihat pada contoh berikut. 
Contoh (2a)

Bidang pendidikan merupakan wadah dan lingkungan formal yang harus menerima anak didik dari semua suku bangsa Indonesia. Oleh karena itu, sesuai dengan pokok kebijaksanaan pendidikan dan kebudayaan dan gbhn maka kedudukan dan fungsi bahasa indonesia dalam hubungannya dengan pendidikan nasional adalah (1) sebagai mata pelajaran dasar dan pokok dan (2) sebagai bahasa pengantar di semua jenjang sekolah. Bahasa daerah dapat dipakai untuk membantu bahasa Indonesia sebagai bahasa pengantar di kelas satu sampai kelas tiga SD di daerah-daerah yang masih memerlukannya. Di samping itu, bahasa daerah dapat pula diajarkan sebagai satu mata pelajaran. Selain itu, juga bahasa daerah dianggap sebagai salah satu media pengembangan kebudayaan.

\section{E. Jenis-Jenis Paragraf}

Berdasarkan fungsinya dan wujudnya dalam karangan paragraf dapat dibagi menjadi tiga jenis, yaitu (1) paragraf pembuka, (2) paragraf pengembang, dan (3) paragraf penutup. Ketiga jenis paragraf itu memiliki fungsi tersendiri yang membedakannya satu sama lain. Secara singkat ketiga jenis paragraf tersebut dapat dijelaskan sebagai berikut :

1. Paragraf Pembuka

Isi paragraf pembuka bertujuan mengutarakan suatu aspek pokok pembicaraan dalam karangan. Sebagai bagian yang mengawali sebuah karangan, paragraf pembuka harus dapat difungsikan untuk : (1) mengantar pokok pembicaraan, (2) menarik minat dan perhatian pembaca, dan (3) menyiapkan atau menata pikiran pembaca untuk mengetahui isi seluruh karangan. 
Disarankan agar paragraf pembuka jangan terlalu panjang agar tidak membosankan.

\section{Paragraf Penghubung}

Paragraf ini bertujuan menghubungkan pokok pembicaraan suatu karangan yang sebelumnya telah dirumuskan di dalam paragraf pembuka. Contoh dan ilustrasi, inti permasalahan dan uraian pembahasan adalah isi sebuah paragraf penghubung atau paragraf pegembang. Paragraf penghubung atau pengembangan berfungsi dalam paragraf untuk : (1) mengemukakan inti persoalan, (2) memberi ilustrasi atau contoh, menjelaskan hal yang akan diuraikan pada paragraf berikutnya, (4) meringkas paragraf sebelumnya, dan (5) mempersiapkan dasar atau landasan bagi kesimpulan. Semua paragraf yang terletak antara paragraf pendahuluan dan paragraf penutup digolongkan sebagai paragraf penghubung. Oleh karena itu, antara paragraf yang satu dan paragraf lainnya harus saling berhubungan secara logis.

\section{Paragraf Penutup}

Paragraf penutup adalah paragraf yang terdapat pada akhir tulisan atau yang mengakhiri sebuah tulisan. Biasanya, paragraf penutup berisi simpulan dari semua pembahasan yang telah dipaparkan pada paragraf penghubung. Paragraf ini sering berisi penegasan atau pernyataan kembali tentang masalah-masalah yang diuraikan pada paragraf penghubung agar maksud penulis menjadi lebih jelas jika ada hal-hal yang dianggap sangat penting. Mengingat paragraf penutup dimaksudkan untuk mengakhiri karangan atau bagian karangan, penyajiannya harus memperhatikan hal berikut ini : (1) sebagai bagian penutup, paragraf ini tidak 
boleh terlalu panjang, (2) isi paragraf harus berisi simpulan sementara atau simpulan akhir sebagai cermin inti seluruh uraian, (3) sebagai bagian yang paling akhir dibaca, hendaknya dapat menimbulkan kesan yang mendalam bagi pembaca, dan (4) isi paragraf penutup banyak ditentukan oleh sifat karangan.

\section{F. Syarat Pembentukan Paragraf}

Sama halnya dengan kalimat, sebuah paragraf juga harus memenuhi syarat-syarat tertentu. Jadi, paragraf yang baik atau efektif adalah sebuah paragraf telah memenuhi syarat-syarat tertentu sebagaimana dijelaskan di bawah ini. Syarat tersebut di antaranya adalah :

\section{(1) Kesatuan pikiran}

Kalimat-kalimat dalam satu paragraf menggambarkan pikiran yang saling berhubungan dan menunjukkan ikatan untuk mendukung satu pikiran sebagai pikiran utama. Kesatuan pikiran dalam paragraf berarti adanya hubungan tentang masalah yang menjadi pikiran utama. Kesatuan pikiran dalam paragraf berarti adanya hubungan tentang masalah yang menjadi pikiran utama. Jadi, tidak boleh ada unsur yang sama sekali tidak berhubungan dengan pikiran tersebut. Penyimpangan uraian akan menyulitkan pembaca memahami maksud penulis.

Contoh :

Industri perkapalan siap memproduksi jenis kapal untuk mengganti kapal yang akan dibesituakan. Akan tetapi kemampuan mereka terbatas. Kalau dalam waktu yang singkat harus memproduksi kapal sebanyak yang harus dibesituakan, jelas industri dalam negeri tidak mampu. Peningkatan kemampuan ini memerlukan waktu. Sebaiknya hal ini dilakukan bertahap. Kalau bentuk peremajaan ini pemerintah sampai mengimpornya dari luar negeri, tentu 
peluang yang begitu besar untuk industri dalam negeri tidak termanfaatkan.

Berdasarkan contoh paragraf di atas dapat dipahami bahwa hanya mengandung satu pikiran utama, yaitu penggantian kapal yang akan dibesituakan. Pikiran utama ini kemudian diperinci dengan beberapa pikiran penjelas, yaitu (1) kesiapan industri perkapalan dalam negeri, (2) kemampuan terbatas, (3) pelaksanaan secara terbatas, dan (4) impor dapat menghilangkan kesempatan. Penjelasan atau perincian itu diurutkan sedemikian rupa sehingga hubungan antara satu kalimat dan kalimat yang lain membentuk kesatuan yang bulat.

\section{(2) Koherensi dan Kepaduan}

Syarat yang kedua harus dipenuhi oleh sebuah paragraf adalah harus mengandung koherensi atau kepaduan. Kepaduan itu terjadi apabila hubungan timbal balik antara kalimat-kalimat yang membina paragraf tersebut tersusun dengan baik. Pembaca dapat dengan mudah memahami dan mengikuti jalan pikiran penulis karena tidak ada loncatanloncatan pikiran yang membingungkan. Kepaduan dalam paragraf dapat dibangun dengan cara-cara tertentu dalam penggunaan bahasa berupa repetisi, kata ganti, dan kata transisi.

\section{(a) Penggunaan repetisi}

Repetisi adalah pengulangan kata kunci, yaitu kata yang dianggap penting dalam sebuah paragraf. Kata kunci mula-mula timbul pada awal paragraf kemudian diulang-ulang pada kalimat berikutnya. Pengulangan itu berfungsi memelihara kepaduan semua kalimat. 
Contoh :

Faktur adalah tanda bukti penjualan barang. Faktur ada yang digabungkan dengan kuitansi dan faktur itu disebut faktur berkuitansi. Faktur berkuitansi cocok dipakai untuk penjualan tunai. Faktur yang kedua adalah faktur tanpa kuitansi. Faktur tanpa kuitansi ini dapat dipakai baik untuk penjualan tunai maupun kredit.

\section{(b) Penggunaan kata ganti}

Kata ganti adalah kata-kata yang mengacu kepada manusia atau benda. Untuk menghindari kebosanan, katakata yang mengacu kepada manusia atau benda itu diganti dengan kata ganti. Pemakaian kata ganti dalam paragraf berfungsi menjaga kepaduan antara kalimat-kalimat yang membangun paragraf. Kata ganti dapat bertugas menunjukkan kepaduan suatu paragraf.

Contoh :

Pak Amir dengan segala senang hati memandangi padi yang tumbuh dengan subur. Ternyata usahanya tidak siasia. Tinggal beberapa minggu lagi ia akan memetik hasilnya. Sekarang telah terbayang di matanya, orang sibuk memotong, memikul padi berkarung-karung, dan menimbunnya di halaman rumah. Tentu anaknya dan istrinya akan ikut bergembira. Hasil padi yang cukup baik ini tentu akan mengantarkan mereka menuju kebahagian.

(c) Penggunaan kata transisi

Kata transisi adalah kata atau frase yang digunakan untuk menghubungkan kalimat yang satu dengan kalimat yang lain untuk menjaga kepaduan paragraf. Sifat hubungan antarkalimat akan menentukan pilihan kata /frase transisi yang dipakai dalam paragraf.

Contoh : 
Jam lima pagi saya bangun. Sesudah itu, saya ke kamar mandi, lalu saya mandi berpakaian. Sesudah itu, saya berpakaian. Setelah berpakaian, saya makan pagi. Sesudah itu, saya pamit pada Ayah dan lbu, lalu saya berangkat sekolah.

Paragraf di atas, menunjukkan bahwa semua hubungan kalimat dikuasai kata transisi yang mengatur hubungan waktu. Penggunaan kata transisi yang sama, seperti contoh di atas kurang baik, karena dapat membosankan membacanya.

Peralihan dari kalimat satu ke kalimat yang lain dalam paragraf dapat dihubungkan atau dikaitkan dengan kata-kata atau frase transisi. Sesuai dengan jenis hubungan yang ditunjukkan atau yang dimaksud, pengguna bahasa dapat memilih kata-kata atau frase transisi di bawah ini sebagai penghubung untuk pengait dalam paragraf.

\begin{tabular}{|l|l|}
\hline $\begin{array}{l}\text { Fungsi } \\
\text { Henyatakan }\end{array}$ & Contoh Kata dan Frase \\
\hline akibat/ hasil & $\begin{array}{l}\text { akibatnya, karena itu, maka, oleh sebab itu, } \\
\text { dengan demikian, jadi, sebab itu }\end{array}$ \\
\hline pertambahan & $\begin{array}{l}\text { berikutnya, demikian juga, kemudian, selain } \\
\text { itu, lagi pula, lalu, selanjutnya, tambahan lagi, } \\
\text { lebih-lebih lagi, di samping itu, seperti halnya, } \\
\text { juga, tambahan, akhirnya, kedua, ketiga, } \\
\text { demikian juga }\end{array}$ \\
\hline perbandingan & $\begin{array}{l}\text { dalam hal yang sama, lain halnya dengan, } \\
\text { sebaiknya, lebih baik dari itu, berbeda } \\
\text { dengan itu, seperti, dalam hal yang demikian, } \\
\text { sebagaimana }\end{array}$ \\
\hline pertentangan & akan tetapi, bagaimanapun, meskipun begitu, \\
\hline
\end{tabular}




\begin{tabular}{|l|l|}
\hline \multirow{2}{*}{ tempat } & $\begin{array}{l}\text { namun, sebaiknya, walaupun demikian, } \\
\text { sebaliknya, sama sekali tidak, meskipun, biar } \\
\text { pun }\end{array}$ \\
\hline tujuan & $\begin{array}{l}\text { berdekatan dengan itu, di sini, di seberang, } \\
\text { di sana, tak jauh dari sana, di bawah, persis } \\
\text { di depan . ., di sepanjang ..., dekat, } \\
\text { berdampingan dengan }\end{array}$ \\
\hline waktu & $\begin{array}{l}\text { Agar, untuk, guna, untuk maksud itu, dengan } \\
\text { maksud tersebut, agar, supaya, }\end{array}$ \\
& $\begin{array}{l}\text { baru-baru ini, beberapa saat kemudian, } \\
\text { mulai, sebelum, segera, sesudah, sejak, } \\
\text { ketika, sementara itu, beberapa saat } \\
\text { kemudian, sesudah itu, setelah }\end{array}$ \\
\hline singkatan & $\begin{array}{l}\text { singkatnya, ringkasnya, akhirnya, sebagai } \\
\text { simpulan, pendek kata, pendeknya, secara } \\
\text { singkat, pada umumnya, seperti sudah } \\
\text { dikatakan, dengan kata lain, misalnya, yakni, } \\
\text { yaitu, sesungguhnya }\end{array}$ \\
\hline
\end{tabular}

\section{G. Teknik Pengembangan Paragraf}

Sebuah paragraf dibangun oleh beberapa kalimat yang saling berhubungan. Kalimat-kalimat tersebut diikat oleh satu pikiran utama dan dijelaskan secara terinci oleh beberapa pikiran penjelas. Pikiran utama dan pikiran penjelas masingmasing tertuang dalam kalimat utama dan kalimat penjelas. Jadi, dalam sebuah paragraf terdapat satu kalimat utama dan beberapa kalimat penjelas. Ada beberapa cara penempatan kalimat utama dalam sebuah paragraf yang sesuai dengan pikiran penulis. Di samping itu, untuk mengembangkan paragraf ada beberapa teknik yang dilakukan sehingga para para penulis lebih mudah menguasai penulisan paragraf tersebut. Selain itu, paragraf dapat dicermati dari segi sifat isinya yang 
sangat bergantung pada pada informasi yang akan disampaikan.

\section{H. Cara Penempatan Pikiran Utama}

(1) Pikiran utama pada posisi awal paragraf

Paragraf dimulai dengan mengemukakan pikiran utama yang tertuang dalam satu kalimat. Penjelasan terhadap pikiran utama tersebut diberikan melalui sejumlah kalimat penjelas. Penempatan kalimat utama pada awal paragraf menunjukkan adanya penelanan pikiran utama yang mudah terbaca oleh pembaca dan dapat mengundang perhatian yang bersangkutan untuk mengikuti penjelasan selanjutnya. Paragraf yang demikian mengikuti cara berpikir deduktif (dari umum ke khusus) sehingga disebut pula paragraf deduktif.

Contoh :

\section{Kebudayaan dapat dilihat dari dua sisi, yaitu} kebudayaan fisik dan nonfisik. Kebudayaan fisik cukup jelas karena merujuk pada benda-benda. Kebudayaan nonfisik ada yang berupa pemikiran dan ada yang berupa wujud tingkah laku. Adapun contoh hasil kebudayaan fisik di antaranya adalah patung, lukisan, rumah, bangunan, mobil, dan jembatan. Contoh kebudayaan yang berupa pemikiran adalah aliran filsafat, pengetahuan, idiologi, etika, dan estetika. Hasil kebudayaan yang berwujud tingkah laku di antaranya adalah sikap, kebiasaan, adat istiadat, belajar, tidur, bertani, bahkan berkelahi.

(2) Pikiran utama pada akhir paragraf

Pikiran utama sebuah paragraf dapat juga ditempatkan pada akhir paragraf. Paragraf jenis ini disusun dengan lebih dahulu mengemukakan kalimat-kalimat penjelas, kemudian disudahi dengan kalimat utama yang memuat pikiran utama. 
Pengembangan pikiran utama dilakukan secara bertahap dan mencapai klimaks pada akhir paragraf.

Contoh :

Kebudayaan suatu bangsa dapat dikembangkan dan dapat diturunkan kepada generasi mendatang melalui bahasa. Semua yang berada di sekitar manusia, misalnya peristiwa-peristiwa, hasil karya manusia, dapat diungkapkan kembali melalui bahasa. Orang sadar bahwa kegiatan dalam masyarakat akan lumpuh tanpa bahasa. Memang, bahasa adalah alat komunikasi yang penting, efektif, dan efesien.

(3) Pikiran utama pada awal dan akhir paragraf

Kalimat utama dapat diletakkan pada awal paragraf dan diulang pada akhir paragraf. Maksud pengulangan ini adalah memberikan tekanan pada pikiran utama paragraf dan sebagai penegasan kembali isi pernyataan yang dikemukakan pada awal paragraf. Kalimat utama yang diulang tidak harus sama dengan kalimat utama yang terdapat pada awal paragraf. Pengulangan tersebut dilakukan dengan mengubah bentuk kata-katanya dan struktur kalimatnya, tetapi pikiran utamanya tetap sama. Paragraf yang demikian merupakan perpaduan paragraf deduktif dan induktif.

Contoh :

Pemerintah menyadari bahwa rakyat Indonesia memerlukan rumah murah, sehat, dan kuat. Kementerian PU sudah lama menyelidiki bahan rumah yang murah, tetapi kuat. Agaknya bahan perlit yang diperoleh dari batu-batuan gunung berapi sangat menarik perhatian para ahli. Bahan ini tahan api dan tahan air. Lagi pula, bahan perlit dapat dicetak menurut bahan keinginan seseorang. Usaha ini menunjukkan bahwa pemerintah berusaha membangun 
rumah murah, sehat, dan kuat untuk memenuhi keperluan rakyat.

6. Paragraf dengan pikiran utama tersirat

Seluruh kalimat yang membangun paragraf sama pentingnya dan bekerja sama menggambarkan pikiran yang terdapat dalam paragraf sehingga tidak satu pun kalimat yang khusus menjadi kalimat topik. Kalimat-kalimat itu merupakan suatu kesatuan isi. Kondisi demikian itu biasa terjadi akibat sulitnya menentukan kalimat topik karena kalimat yang satu dengan yang lainnya sama-sama pentingnya. Paragraf semacam ini sering dijumpai dalam uraian-uraian yang bersifat deskriptif dan naratif terutama dalam karangan fiksi.

Contoh :

Pagi hari itu aku duduk di bangku panjang dalam taman di belakang rumah. Matahari belum tinggi benar, baru sepenggalah. Sinarnya mengusir dingin menghangatkan badan. Di depanku bermekaranlah bunga beraneka warna. Angin pegunungan sepoi-sepoi basah membelai wajah, membawa bau harum bunga dan rasa manis madunya. Kuhirup udara pagi sepuas-puasku. Nyaman rasa badan dan hilanglah lelah berjalan sehari suntuk kemarin.

Pengurutan Kalimat Utama dan Kalimat Penjelas

Kalimat utama dan kalimat-kalimat penjelas dapat disusun menjadi paragraf yang baik dengan menggunakan urutan tertentu. Urutan kalimat dalam paragraf dapat disusun menurut urutan logis, urutan kronologis, urutan klimaks, dan urutan antiklimaks. Urutan-urutan tersebut akan dijelaskan secara singkat.

1. Urutan logis

Urutan logis adalah urutan yang menyebutkan lebih dahulu hal-hal yang umum lalu ke hal-hal yang khusus atau 
sebaliknya. Jadi, boleh dikatakan bahwa kalimat-kalimat yang memuat pikiran penulis diurut secara sintesis atau analitis Contoh

(1)Manusia adalah ciptaan Tuhan yang paling sempurna dan paling berkuasa di bumi atau di dunia. (2) dikatakan demikian sebab ia dizinkan oleh Tuhan memanfaatkan semua isi alam ini untuk keperluan hidupnya. (3) meskipun demikian, manusia tidak dizinkan menyakiti, menyiksa, atau menyia-nyiakannya.

Dalam paragraf di atas urutan kalimat (1), (2), dan (3) menunjukkan jalan pikiran yang masuk akal (logis) atau penalaran yang wajar. Apabila kalimat-kalimat tersebut diubah urutannya akan mengakibatkan jalan pikiran itu tidak akan logis. Misalnya, diubah susunannya menjadi (1), (3), dan (2), atau (3), (1), dan (2), atau (2), (1), dan (3). Jika dicermati susunan isi paragraf tidak akan logis atau tidak berterima.

2. Urutan kronologis

Urutan kronologis adalah urutan kejadian menurut waktu. Peristiwa yang digambarkan dalam paragraf diurut menurut tingkat perkembangannya dari waktu ke waktu. Urutan tersebut dipakai pada jenis tulisan naratif. Contoh

(1)Tepat jam 08.00 upacara peringatan hari Kemerdekaan dimulai. (2) bendera Merah Putih dikibarkan diiringi lagu kebangsaan Indonesia Raya. (3) Peserta upacara mengheningkan cipta untuk mengenang jasa para pahlawan yang telah gugur. (4) Dua mahasiswa untuk tampil membacakan teks Proklamasi dan Pembukaan UndangUndang Dasar 1945. (4) Sesudah itu, rektor menyampaikan pidato sambutan tentang Proklamsi Kemerdekaan Republik Indonesia pada tanggal 17 Agustus 1945. (6) Kira-kira jam 10.00 upacara diakhiri dengan pembacaan doa. 


\section{Urutan klimaks dan antiklimaks}

Dalam paragraf klimaks dan antiklimaks mula-mula disebutkan pernyataan atau kejadian biasa. Kemudian lambatlaun meningkat menjadi makin penting, makin menonjol atau tegang, sampai pada yang paling penting atau sangat menonjol. Singkatnya, kalimat yang terakhir dari paragraf tersebut merupakan pernyataan yang paling penting dan menjadi klimaks dari serangkaian pernyataan sebelumnya. Hal sebaliknya dapat juga dilakukan dimulai dari hal yang paling penting dan semakin lama sampai ke hal-hal yang dianggap tidak terlalu penting atau diakhir kalimat kadar kepentingannya semakin menurun.

Contoh Paragraf Klimaks (a)

(1)Pancasila telah beberapa kali dirongrong. (2) Beberapa kali falsafah negara RI hendak diubah atau pun dipreteli. (3) Setiap usaha hendak mengubah dan mempreteli Pancasila ternyata gagal. (4) Betapa pun usaha itu telah dipersiapkan dengan matang dan teliti, semuanya tetap dapat dihancurkan. (5) Memang, Pancasila benar-benar sakti.

\section{Contoh Paragraf Antiklimaks(b)}

(1)Kebahagiaan tidak semata-mata ditentukan oleh banyaknya uang yang dimiliki oleh seseorang. (2)Uang memang penting, tetapi kebahagiaan seseorang tidak bergantung kepada uang yang dimilikinya. (3)Jika kebahagiaan memang tergantung kepada uang semata-mata, pastilah hanya orang-orang kaya saja yang dapat menikmati kebahagiaan. (4) Kenyataannya tidak demikian. (5)Banyak orang yang kaya harta, tetapi tidak berbahagia. (6)Sebaliknya, banyak orang yang miskin harta, tetapi berbahagia hidupnya.

\section{Jenis Paragraf Menurut Sifat Isinya}

Isi sebuah paragraf bermacam-macam bergantung pada maksud penulisnya dan tuntutan konteks serta sifat 
informasi yang akan disampaikan. Penyelarasan sifat isi paragraf dengan isi karangan sebenarnya cukup beralasan karena telah dijelaskan bahwa kegiatan menyusun paragraf adalah pekerjaan yang termasuk mengarang. Oleh karena itu, ada beberapa hal yang prinsif dalam penulisannya mengandung kesamaan antara paragraf (karangan sederhana) dan karangan kompleks yang terdiri atas beberapa paragraf. $\mathrm{Di}$ antaranya adalah sama-sama mempunyai topik, tema, dan outline. Memang di dalam paragraf unsur-unsur tersebut berwujud sederhana.

Secara ringkas dapat dilihat di bawah ini tentang klasifikasi paragraf berdasarkan sifat isinya. Di antaranya terdapat dalam tabel sebagai berikut.

\begin{tabular}{|l|l|}
\hline $\begin{array}{l}\text { Jenis Paragraf } \\
\text { Menurut Sifat Isinya }\end{array}$ & Isi Pragraf \\
\hline $\begin{array}{l}\text { paragraf persuasif } \\
\text { paragraf argumentatif } \\
\text { paragraf naratif } \\
\text { paragraf deskriptif } \\
\text { paragraf ekspositoris }\end{array}$ & $\begin{array}{l}\text { mempromosikan sesuatu dengan cara } \\
\text { memengaruhi atau mengajak } \\
\text { pembaca membahas satu masalah } \\
\text { dengan bukti-bukti atau alasan yang } \\
\text { mendukung menuturkan peristiwa } \\
\text { atau keadaan dalam bentuk ceritra } \\
\text { melukiskan atau menggambarkan } \\
\text { sesuatu dengan bahasa memaparkan } \\
\text { sesuatu dengan fakta atau kejadian } \\
\text { tertentu }\end{array}$ \\
\hline
\end{tabular}

Pragraf persuasif banyak dipakai dalam penulisan iklan, terutama advertorial yang sering mengisi lembaran koran dan majalah. Paragraf argumentatif, deskriptif, dan ekspositoris umumnya digunakan dalam karangan ilmiah, seperti makalah, buku, skripsi, tesis, disertasi, dan laporan. Dalam tulisan ilmiah, ketiga jenis paragraf itu bergabung saling berhubungan antara satu dan lainnya dalam sebuah 
karangan. Selanjutnya, secara spesifik jenis paragraf ekspositoris sebagian besar digunakan menulis berita dalam surat kabar, sedangkan jenis paragraf naratif sering dipakai dalam menulis karangan fiksi atau karangan nonilmiah, seperti cerpen, novel, roman, dan beberapa jenis karya sastra lainnya.

\section{(1) Paragraf Narasi}

Pengertian paragraf narasi adalah paragraf yang menceritakan suatu peristiwa atau kejadian yang didalamnya terdapat alur cerita, setting, tokoh, dan konflik, tetapi tidak memiliki kalimat utama.

Contoh

Jam istirahat, Riska menulis hasil bacaan yang diperoleh dari buku cetak di perpustakaan IAIN Palopo yang akan dijadikan sebagai bahan penulisan skripsi ke dalam buku agendanya sambil menikmati bekal dari rumah. Sesekali kepalanya menengadah ke langit-langit perpustakaan, mengernyitkan kening, tersenyum, dan kembali menulis. Asyik sekali, seakan di ruang perpustakaan hanya dia seorang diri.

(2) Paragraf Deskripsi

Pengertian Paragraf deskripsi adalah menggambarkan sesuatu dengan jelas dan terperinci. Paragraf deskrispi bertujuan melukiskan atau memberikan gambaran terhadap sesuatu dengan sejelas-jelasnya sehingga pembaca seolah-olah dapat melihat, mendengar, membaca, atau merasakan hal yang dideskripsikan.

Contoh

Gadis itu menatap Makmur dengan tersenyum. Hati Makmur semakin gencar memuji gadis yang mempesona di hadapanya. Ya, karena memang gadis di depannya itu sangat cantik. Rambutnya hitam lurus hingga melewati garis 
pinggang. Matanya bersinar lembut dan begitu dalam, memberikan pijar mengesankan yang misterius. Selain itu, ditambah kulitnya yang putih bersih, bagai putih kuning lasat, dagu lancip yang menawan, serta bibir berbelah, dia sungguh tampak sempurna.

\section{(3) Paragraf Argumentasi}

Pengertian paragraf argumentasi adalah karangan yang membuktikan kebenaran tentang sesuatu. Untuk memperkuat ide atau pendapatnya penulis wacana argumetasi menyertakan data-data pendukung. Tujuannya, pembaca menjadi yakin atas kebenaran yang disampaikan penulis.

Contoh

Sebagian anak Indonesia belum dapat menikmati kebahagiaan masa kecilnya. Pernyataan demikian pernah dikemukakan oleh seorang pakar psikologi pendidikan Sukarton (1992) bahwa anak-anak kecil di bawah umur 15 tahun sudah banyak yang dilibatkan untuk mencari nafkah oleh orang tuanya. Hal ini dapat dilihat masih banyaknya anak kecil yang mengamen atau mengemis di perempatan jalan atau mengais kotak sampah di TPA. Kemudian, hasilnya diserahkan kepada orang tuanya untuk menopang kehidupan keluarga. Apa lagi, sejak di negeri kita terjadi krisis moneter, kecenderungan orang tua mempekerjakan anak sebagai penopang ekonomi keluarga semakin terlihat di mana-mana.

(4) Paragraf Persuasi

Pengertian paragrap persuasi adalah paragraf yang mengungkapkan ide, gagasan, atau pendapat penulis dengan disertai bukti dan fakta (benar-benar terjadi). Contoh

Dalam diri setiap bangsa Indonesia harus tertanam 
nilai cinta terhadap sesama manusia sebagai cerminan rasa kemanusiaan dan keadilan. Nilai-nilai tersebut di antaranya adalah mengakui dan memperlakukan manusia sesuai dengan harkat dan martabatnya, mengembangkan sikap tenggang rasa dan nilai-nilai kemanusiaan. Sebagai sesama anggota masyarakat, kita harus mengembangkan sikap tolong-menolong dan saling mencintai. Dengan demikian, kehidupan bermasyarakat dipenuhi oleh suasana kemanusian dan saling mencintai.

(5) Paragraf Eksposisi

Pengertian Paragraf eksposisi adalah karangan yang menyajikan sejumlah pengetahuan atau informasi. Tujuannya, pembaca mendapat pengetahuan atau informasi yang sejelasnya.

Contoh

Para pedagang daging sapi di pasar-pasar tradisional mengeluhkan dampak pemberitaan mengenai impor daging ilegal. Sebab, hampir seminggu terakhir mereka kehilangan pembeli sampai 70 persen. Sebaliknya, permintaan terhadap daging ayam dan telur kini semakin melejit sehingga harganya meningkat.

\section{Pola Pengembangan Paragraf}

1. Pola Pengembangan dengan Cara Umum-Khusus

Metode umum-khusus dan khusus-umum paling banyak dipakai untuk mengembangkan gagasan paragraf agak tampak teratur. Bagi penulis pemula, belajar menyusun paragraf dengan mengunakan metode atau pola ini adalah cara yang paling disarankan. Pertimbangannya, di samping mengembangkan urutan umum-khusus, juga relatif mudah dikembangkan. Selain itu, pola atau teknik tersebut paling banyak dipakai dalam karangan ilmiah dan tulisan 
ekspositorias, seperti artikel dalam media massa. Cara ini digunakan dalam menulis paragraf dapat dilakukan, baik dari umum ke khusus atau sebaliknya dari khusus ke umum. Dalam bentuk umum ke khusus, pikiran utama diletakkan pada awal paragraf lalu diikuti dengan perincian-perincian.

Contoh :

\section{(1)Salah satu kedudukan bahasa Indonesia adalah} sebagai bahasa nasional. (2) Kedudukan ini dimiliki sejak dicetuskannya Sumpah Pemuda pada tanggal 28 Oktober 1928. (3) Kedudukan ini dimungkinkan oleh kenyataan bahwa bahasa Melayu yang mendasari bahasa Indonesia dan telah menjadi lingua franca selama berabad-abad di seluruh tanah air kita. (4) Hal ini ditunjang lagi oleh faktor tidak terjadinya "persaingan bahasa", maksudnya persaingan bahasa daerah yang satu dengan bahasa daerah yang lain untuk mencapai kedudukannya sebagai bahasa nasional.

Pengembangan paragraf deduktif didiagramkan sebagai berikut :

Umum (1)

Khusus (2)

Khusus (3)

Khusus (4)

Penulis dapat memilih cara lain dalam mengembang paragraf, yaitu dengan menggunakan teknik khusus-umum. Penulisan dimulai dari rincian-rincian (kekhususan) dan selanjutnya pada akhir paragraf disimpulkan pikiran utamanya. Jadi, dalam pengembangan paragraf ini dipakai pola khususumum.

(1)Dokumen dan keputusan serta surat-menyurat yang dikeluarkan pemerintah dan badan kenegaraan lainnya ditulis dalam bahasa Indonesia. (2) Pidato-pidato 
terutama pidato kenegaraan ditulis dan diucapkan dalam bahasa Indonesia. (3) Hanya dalam keadaan tertentu, demi kepentingan komunikasi antara bangsa, kadangkadang pidato resmi ditulis dan diucapkan dalam bahasa asing, terutama bahasa Inggris. (4)Demikian juga bahasa Indonesia dipakai oleh masyarakat dalam upacara, peristiwa, dan kegiatan kenegaraan atau sebagai alat komunikasi timbal balik antara pemerintah dan masyarakat.

Pengembangan paragraf induktif didiagramkan sebagai berikut :

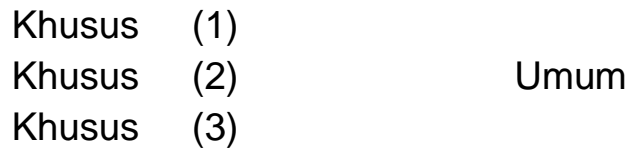

Khusus (3)

2. Pengembangan dengan Cara Alasan-Alasan

Dalam pengembangan menurut pola ini, fakta yang menjadi sebab terjadinya sesuatu itu dikemukakan lebih dahulu, kemudian disusul rincian-rincian sebagai akibatnya. Dalam hal ini, sebab merupakan pikiran utama, sedangkan akibat merupakan pikiran-pikiran penjelas.

Contoh :

\section{(1)Keluarga berencana berusaha menjamin} kebahagiaan hidup keluarga. (2) Ibu tidak selalu hidup merana karena setiap tahun melahirkan. (3) Bapak tidak terlalu pusing memikirkan usaha untuk mencukupi kebutuhan keluarganya. (4) Anak pun tidak terlantar hidupnya.

Paragraf ini tergolong deduktif. Kalimat (1) merupakan sebab, sedangkan kalimat (2), (3), dan (4) merupakan akibat. Pengembangan ini dapat didiagramkan sebagai berikut :

Akibat (2)

Sebab (1)

Akibat (3)

Akibat 
Kebalikan adalah pengembangan yang menggunakan pola akibat-sebab. Dalam hal ini, akibat suatu kejadian merupakan pikiran utama, sedangkan sebab merupakan pikiran penjelas.

Contoh

(1)Dia terpaksa tidak masuk sekolah hari ini. (2) Sudah beberapa hari ibunya sakit. (3) Ayahnya yang dinantinantikan kedatangannya dari Jakarta belum tiba. (4) Adikadiknya yang masih kecil tidak ada yang menjaganya.

Pengembangan paragraf dapat digambarkan pada diagramkan sebagai berikut :

$\begin{array}{cc} & \text { sebab (2) } \\ \text { Akibat } & \text { sebab (3) } \\ & \text { sebab (4) }\end{array}$

Dalam penyusunan karya ilmiah, pengembangan sebab-akibat lebih banyak digunakan daripada pengembangan akibat-sebab. Hubungan sebab-akibat berperan penting dalam uraian ilmiah, seperti makalah, skripsi, dan tesis.

3. Pengembangan dengan Cara Perbandingan

Pada pola pengembangan paragraf ini, penulis memaparkan persamaan dan perbedaan dua objek/ gagasan atau lebih. Perbandingan tersebut dapat dilakukan karena objek yang berbeda itu mempunyai persamaan tertentu dan juga perbedaan tertentu.

Contoh :

(1)Pantun dan syair mempunyai beberapa persamaan dan perbedaan. (2) Keduanya tergolong puisi lama yang terdiri atas empat baris. (3) Pada syair, keempat barisnya merupakan isi, sedangkan pada pantun isinya terletak pada baris ketiga dan keempat. (4) Pantun berasal dari bumi 
Indonesia, sedangkan syair berasal dari sastra Arab.

4. Pengembangan dengan Cara Contoh-Contoh

Dalam pola pengembangan seperti ini terlebih dahulu dikemukakan suatu pernyataan, kemudian disebutkan rincianrincian berupa contoh-contoh konkret. Dalam karangan ilmiah contoh dan ilustrasi selalu ditampilkan. Contoh-contoh terurai, lebih-lebih yang memerlukan penjelasan rinci tertentu. Perhatikan ilustrasi dalam bentuk paragraf yang ditulis dengan menggunakan pola pengembangan dengan contoh.

Contoh :

(1)Kata-kata pungutan itu ada yang telah lama masuk, ada juga yang baru masuk. (2) Baik yang telah lama maupun yang baru, ada yang benar-benar menjadi warga bahasa Indonesia, misalnya: saya, sabun, pasar, kursi meja, dsb. (3) Ada juga yang masih terasa asingnya, misalnya : insaf, sukses, akhlak, proses, dan sebagainya.

\section{Pengembangan dengan Cara Definisi Luas}

Definisi luas ini dapat dipakai untuk mengembangkan pikiran utama. Semua penjelas atau uraian menuju pada perumusan definisi tersebut. Jadi, definisi adalah usaha penulis untuk menerangkan pengertian atau konsep istilah tertentu. Untuk merumuskan definisi yang jelas, penulis hendaknya memperhatikan klasifikasi definisi konsep dan penentuan ciri khas konsep tersebut.

Contoh :

Apa dan siapakah pahlawan itu ? Pahlawan adalah orang yang berpahala. Mereka yang berbuat baik, melaksanakan kewajiban dengan baik, berjuang tanpa pamrih adalah pahlawan. Pahlawan tidak menuntut balas jasa, tidak ingin dihargai, tidak meminta pengakuan dari orang lain. Mereka berbuat berdasarkan idealisme, cita-cita luhur, 
berjuang untuk kepentingan umum, membela nusa, bangsa, dan negara. Pahlawan sejati adalah pahlawan yang tidak menonjolkan diri, tidak ingin disanjung dan dijunjung. Pahlawan itu berjuang dengan ikhlas, rela berkorban tanpa pamrih.

6. Pengembangan dengan Cara Campuran

Pada pola pengembangan ini rincian terhadap kalimat utama terdiri atas campuran dari dua atau lebih cara pengembangan paragraf. Jadi, misalnya terdapat campuran umum khusus dengan sebab akibat, atau dengan perbandingan dan sebagainya.

Contoh :

(1)Bahasa tutur adalah bahasa pergaulan yang dipakai dalam kehidupan sehari-hari, terutama dalam percakapan. (2) Umumnya bahasa tutur sederhana dan singkat bentuknya. (3) Kata-kata yang digunakan tidak banyak jumlahnya. (4) Lagi pula bahas tutur hanya menggunakan kata-kata yang lazim dipakai sehari-hari. (5) Sudah barang tentu sering digunakan juga kata tutur, yaitu kata yang memang hanya boleh dipakai dalam bahasa tutur, misalnya : bilang, pelan, bikin, enggak, dan sebagainya. (7) Lafalnya pun sering menyimpang dari lafal yang umum, misalnya : dapet (dapat), malem (malam), dsb.

\section{Pengembangan dengan Cara Proses}

Sebuah paragraf dikatakan memakai metode proses apabila isi paragraf menguraikan suatu proses. Proses merupakan suatu urutan tindakan atau perbuatan untuk menciptakan atau menghasilkan sesuatu. Bila urutan atau tahap-tahap kejadian berlangsung dalam waktu yang berbeda, penulis harus menyusun secara runtut. Di bawah ini disajikan 
contoh paragraf yang menggunakan pengembangan pola proses.

Contoh

Proses pembuatan kue donat adalah sebagai berikut.
Mula-mula dibuat adonan terigu dicampur dengan telur dan
gula dengan perbandingan tertentu yang ideal sesuai
dengan banyaknya kue donat yang akan dibuat. Kemudian,
adonan dicetak dalam bentuk gelang-gelang. Setelah itu,
"gelang-gelang" tadi digoreng sampai berwarna kuning
kecoklatan. Selanjutnya, gorengan itu diolesi mentega,
diberi butiran coklat warna-warni, atau ditaburi tepung gula.
Akhirnya, kue donat siap untuk disantap.

8. Pengembangan dengan Cara Klasifikasi

Pengembangan dengan cara mengklasifikasi atau mengkelompok-kelompokkan masalah yang dikemukakan. Dengan klasifikasi itu diharapkan penulis lebih mudah mengembangkan dan menata alur pikiran yang akan ditulis dalam paragraf. Di samping itu, pembaca dapat lebih mudah memahami informasi yang disajikan.

Contoh

Dewasa ini ada berbagai sumber yang dapat dimanfaatkan sebagai pembangkit tenaga listrik. Sumbersumber itu selain berupa tenaga air dan tenaga matahari, dapat pula berupa tenaga panas bumi dan tenaga nuklir. Sebagai pembangkit listrik, nuklir telah dimanfaatkan hampir di seluruh dunia.

9. Pengembangan dengan Cara Fakta

Pengembangan dengan fakta merupakan suatu bentuk pengembangan paragraf yang dilakukan dengan menyertakan sejumlah fakta atau bukti-bukti untuk memperkuat pendapat yang dikemukakan. Fakta-fakta dapat dihubungkan menjadi satu paragraf apabila dapat menggambarkan sifat-sifat khusus 
seseorang pribadi atau bagian suatu pemandangan atau segi masalah lainnya.

Contoh

Kesan pertama setelah bertemu dengan pria ini
adalah menyenangkan, tetapi wibawanya tetap memantul.
Perawakannya sedang, tidak terlalu besar dan tidak pula
terlalu kecil. Rambutnya lurus disisir ke belakang. Dahinya
lebar, kata orang menandakan pandangannya luas. Kulitnya
agak hitam. Bicaranya kalem dan hati-hati. Nada bicaranya
bersahabat, tidak seperti menggurui. Apa yang akan
dikeluarkan mulutnya tampak telah melewati saringan pikiran
yang arif.

10. Pengembangan dengan Cara Pertanyaan

Mengembangkan paragraf dengan cara ini berarti menyusun kalimat topik dalam bentuk kalimat tanya. Dengan menggunakan pertanyaan dalam paragraf berarti penulis mencoba untuk menghidupkan kesan dari pesan yang ingin disampaikannya,

Contoh

Tahun depan adalah tahun pelaksanaan pemilihan umum. Perlukah kita mendoakan agar sukses pemilu itu? Masih perlukah kita berjuang agar Pancasila dan UUD 1945 menjadi dasar negara kita? Apakah semuanya telah diatur dari atas? Mungkinkah pelaksanaan dan hasil pemilu telah meyakinkan dengan baik kepada kita. Terjaminkah hasil pemilu dengan manipulasi yang menjadikan kita seperti boneka yang hanya menunggu komando dari sang dalang dengan berbagai aparaturnya? Tegasnya, selamatkan negara dan bangsa kita dari pembagian kursi DPR pada pesta demokrasi sebagai wahana penyambut aspirasi masyarakat. 


\section{BAB VI \\ KETERAMPILAN MEMBACA}

egiatan membaca memiliki peranan sosial amat penting dalam kehidupan manuisa sepanjang masa karena melalui kegiatan membaca, pembaca akan memperoleh pesan informasi yang hendak disampaikan penulis melalui media kata-kata atau bahasa tulis. Dari aspek linguistik, membaca adalah proses penyandian kembali dan pembacaan sandi (a recording and decoding process), berbeda dengan berbicara dan menulis yang melibatkan aspek penyandian (encoding). Kegiatan aspek pembacaan sandi (decoding) adalah menghubungkan kata-kata tulis (written word) dengan makna bahasa lisan (oral language meaning) yang mencakup pengubahan tulisan/cetakan menjadi bunyi yang bermakna.

Tujuan utama dalam membaca adalah untuk mencari serta memperoleh informasi, mencakup isi serta memahami makna bacaan._ Dalam kaitannya dengan kegiatan membaca secara garis besar terdapat dua aspek penting dalam membaca. Pertama, keterampilan yang bersifat mekanis (mechanical skills) yang berada pada urutan yang lebih rendah (lower order). Aspek ini mencakup: pengenalan bentuk huruf, pengenalan unsur-unsur linguistik, seperti fonem/grofem, kata, frase, pola klausa, kalimat,dan sebagainya. Kedua, kecepatan membaca bertaraf lambat, yaitu keterampilan yang bersifat pemahaman (comprehension skills) yang berada pada urutan yang lebih tinggi (higher order). Aspek ini mencakup: memahami pengertian sederhana (leksikal, gramatikal, retorikal), memahami signifikansi atau makna, evaluasi atau penilaian (isi, bentuk), dan kecepatan 
membaca yang fleksibel, yang mudah disesuaikan dengan keadaan.

Banyak orang mengahdapi buku atau bacaaan lain dengan cara membaca dari awal sampai akhir. Melalui cara demikian mereka beranggapan akan menguasai isi bacaan. Hal tersebut tidak benar. Mereka harus membaca berulangulang dengan menggunakan langkah yang strategis untuk menguasai dan mengingat bahan bacaan itu lebih lama. Usaha yang efektif untuk mengetahaui dan mengingat lebih lama dapat dilakukan dengan (1) mengorganisasikan bahan yang dibaca agar mudah dipahami dan (2) mengaitkan fakta yang satu dengan yang lain atau menghubungkan dengan pengalaman pembaca. Selanjutnya, agar pembaca memahami isi bacaan secara komprehensip ide pokok atau detail yang penting diperlukan (1) penguasaan perbendaharaan katanya (diksi) dan akrab dengan struktur dasar dalam penulisan (kalimat, paragraf, dan tata bahasa), (Soedarso, 1989: 58)

\section{A. Teknik Membaca SQ3R}

Soedarso (1989: 59-78) sistem membaca SQ3R dikemukakan Francis P. Robinson tahun 1941 merupakan sistem membaca yang semakin populer digunakan masyarakat. SQ3R adalah proses membaca yang terdiri atas lima langkah: survey, question, read, recite (recall), dan review.

\section{Langkah 1: S-Survei}

Survei atau prabaca adalah teknik mengenal bahan sebelum membaca secara lengkap, dilakukan untuk mengetahui organisasi dan ikhtisar umum yang akan dibaca dengan maksud untuk:

1. mempercepat mengangkap arti

2. mendapatkan abstrak 
3. mengetahui ide-ide yang penting

4. melihat susunan (organisasi) bahan bacaan

5. memperoleh minata atau perhatian terhadap bacaan, dan

6. memudahkan mengingat lebih banyak dan memahami lebih mudah.

Survei atau prabaca buku, tindakan yang pertama perlu dilakukan adalah memperhatikan judul buku dan mengajukan pertanyaan tentang topik buku. Kemudian, milihat nama penulis dan atributnya yang biasanya memberi petunjuk isi tulisan. untuk melihat aktualisasinya, lihat tahun terbitnya, baca sampul buku bagian belakang kalau ada yang memuat pesan penulis. Tahap berikutnya adalah: telusuri daftar isi, baca pengantar, lihat tabel grafik dan lain-lain, apendiks, dan dan telusuri indeks.

\section{Langkah 2: Q-Question}

Bersamaan pada saat survei, diajukan pertanyaan sebanyak-banyaknya tentang isi bacaan tersebut yang terkait dengan judul, bab, dan subab atau subjudul. Gunakan kata "siapa, apa, kapan, di mana, atau mengapa". Dengan adanya berbagai pertanyaan cara membaca kita menjadi lebih aktif dan mudah menangkap gagasan daripada hanya sekedar asal membaca.

\section{Langkah 3: R-Read}

Setelah memperoleh jawaban dari bahan bacaan yang dihadapi maka langkah berikutnya adalah membaca (read). Jadi, membaca dilakukan pada langkah ketiga untuk menguasai bacaan. Cara membaca yang digunakan adalah membaca secara kritis. Menelusuri dari bab ke subbab mencari jawaban-jawaban atas pertanyaan yang muncul sehubungan dengan topik bacaan. Dalam tahap ini konsentrasikan pada penguasaan ide pokok serta detail yang penting yang mendukung ide pokok. Perlambata cara 
membaca pada gaian yang penting dan sulit dimengerti dan percepat pada bagian yang dianggap tidak penting dan sudah diketahui.

Tahapan membaca pada bagian ini ada dua hal yang harus dihindari, yaitu (1) jangan membuat catatan karena akan memperlambat dalam membaca dan akan menjadi kutipan kata-kata dari penulisnya saja dan (2) jangan membuat tandatanda seperti garis bawah pada kata maupun frase tertentu karena dapat terjadi setelah selesai membaca sering terjadi salah memilinnya. Jika ada yang menarik atau dianggap cuup penting diberi tanda silang di pinggir halaman dahulu. Kemudiaan, nanti dapat dicek kembali. Pada tahapan membaca ini, konsentrasikan diri untuk menemukan ide pokoknya serta mengetahui detail yang penting.

\section{Langkah 4: R-Recite atau Recall}

Setiap selesai membaca satu bagian, berhentilah sejenak dan coba menjawab pertayaan yang penting dari bagin atau dari bab tersebut. Pada kesempatan itu, dapat juga dibuat catatan seperlunya. Jika masih merasa kesulitan, ulangi membaca bab itu sekali lagi. Selain itu, pastikan bahwa telah melalui empat langkah meskipun bahan bacaan itu mudah. Hal ini dimaksudkan agar bahan yang dibaca dapat tersimpan lama dalam memori kita. Pada tahap ini disiapkan waktu setengah dari waktu keseluruhan membaca dalam lima langkah.

\section{Langkah 5: R-Review}

Daya ingat kita sangat terbatas, meskipun pada waktu membaca $85 \%$ kita menguasai isi bacaan. Dalam waktu 8 jam kemampuan kita untuk mengingat detail yang penting tinggal $40 \%$. Selanjutnya, dalam masa dua pekan pemahaan kita tinggal $20 \%$. Oleh karena itu janganlah lewatkan langkah yang terakhir ini (review). Setelah selesai keseluruhan dari apa yang harus dibaca, ulangi untuk menelusuri kembali judul- 
judul dan subjudul dan bagian penting lainnya dengan menemukan pokok-pokok penting yang perlu untuk diingat kembali. Tahapan langkah ini bertujuan membantu daya ingat dan memperjelas pemahaman. Selain itu, untuk memperoleh hal-hal penting yang mungkin kita lewati sebelumnya.

Ada beberapa aspek yang menjadi penekanan sekligus sebagai teknik untuk menelusuri bahan bacaan. Hal tersebut akan menjadi penuntun bagi pembaca untuk memudah mengenali, mengetahui, memahami, dan memperoleh sejumlah informasi yang dianggap pening dalam bahan bacaan. Di antaranya adalah:

1. Menemuka ide pokok, seperti ide pokok buku keseluruhan, ide pokok bab, ide pokok bagian bab atau subbab, dan ide pokok paragraf.

2. Mengetahui ide pokok paragraf, seperti di awal paragraf, di akhir paragraf, di awal dan akahir paragraf, dan ada di seluruh paragraf.

3. Mengenali detail penting, seperti ditulis kursif (huruf miring), digarisbawahi, dicetak tebal, dibubuhi angka-angka, dan ditulis dengam menggunakan huruf: a, b, dan c. Selain itu, menggunakan kata kunci penuntun, seperti ungkapan penekanan, kata yang mengubah arah, kata illustrasi, kata tambahan, dan kata simpulan.

4. Membaca secara kritis, seperti mengerti isi bacaan, menguji sumber penulis, ada interaksi antara penulis dan pembaca, dan menerima atau menolak.

5. Mengingat lebih lama, seperti mengerti bukan menghafal dan langkah-langkah untuk mengingat.

6. Membuat catatan, seperti manfaat catatan, pokok-pokok yang dicatat, jenis catatan, banyknya sumber, akurat, lembaran dan buku tulis, dan sistem kartu. 
Kegiatan jenis membaca ditinjau dari segi terdengar atau tidaknya suara dalam membaca maka prosesnya dapat dibedakan menjadi dua bagian yaitu:

\section{Membaca Nyaring}

Membaca nyaring adalah suatu aktivitas atau kegiatan yang merupakan alat untuk menangkap serta memahami informasi, pikiran dan perasaan seorang pengarang. Membaca nyaring yang baik menuntut agar si pembaca memiliki kecepatan mata yang tinggi serta pandangan mata yang jauh karena mereka harus melihat pada bahan bacaan untuk memelihara kontak mata dengan para pendengar.

\section{Membaca dalam Hati}

Pada saat membaca dalam hati, kita hanya mempergunakan ingatan visual (visual memory), yang melibatkan pengaktifan mata dan ingatan. Tujuan utama membaca dalam hati (silent reading) adalah untuk memperoleh informasi. Membaca dalam hati dapat dibedakan menjadi dua bagian, yaitu:

\section{a. Membaca Ekstensif}

Membaca ekstensif berarti membaca secara luas. Obyeknya meliputi sebanyak mungkin teks dalam waktu yang sesingkat mungkin. Oleh karena itu, yang menjadi tujuan dan tuntutan kegiatan membaca ekstensif adalah memahami isi bacaan yang penting-penting dengan cepat. Dengan demikian, membaca secara efisien dapat terlaksana. Membaca ekstensif terdiri atas:

1) Membaca survei, sebelum mulai membaca maka biasanya diteliti terlebih dahulu apa-apa yang akan ditelaah. Kita mensurvei bahan bacaan yang akan dipelajari, yang akan ditelaah, dengan cara: memeriksa, meneliti indeks-indeks daftar kata-kata 
yang terdapat dalam buku-buku, judul-judul bab yang terdapat dalam buku-buku yang bersangkutan.

2) Membaca sekilas adalah sejenis membaca yang membuat mata kita bergerak dengan cepat melihat, memperhatikan bahan tertulis untuk mencari serta mendapatkan informasi atau penerangan. Ada tiga tujuan utama dalam membaca sekilas, yaitu: (1) untuk memperoleh kesan umum dari buku atau artikel, tulisan singkat, (2) untuk menemukan hal tertentu dari bahan bacaan, (3) untuk menemukan atau menempatkan bahan yang diperlukan dalam perpustakaan.

3) Membaca dangkal, atau superficial reading pada dasarnya bertujuan memperoleh pamahaman yang dangkal yang bersifat luaran yang tidak mendalam dari bahan bacaan. Membaca superficial ini biasanya dilakukan apabila kita membaca untuk kesenangan, membaca bacaan ringan yang mendatangkan kebahagiaan di waktu senggang. Misalnya, cerita pendek, novel ringan, dan sebagainya.

\section{b. Membaca Intensif}

Membaca intensif atau intensive reading adalah studi seksama, telaah teliti, dan penanganan. Kuesioner, latihan pola-pola kalimat, latihan kosakata, telaah kata-kata, dikte, dan diskusi umum merupakan bagian dan teknik membaca intensif. Kegiatan membaca yang termasuk ke dalam kelompok membaca intensif.

1) Membaca telaah isi

Menelaah isi bacaan menuntut ketelitian, pemahaman, kekritisan berpikir, serta ketrampilan menangkap ide-ide yang tersirat dalam bahan bacaan.

2) Membaca telaah bacaan 
Pada hakikatnya segala sesuatu terdiri atas bentuk dan isi, atas form and meaning, atau jasmani dan rohani. Demikian halnya bacaan, terdiri atas isi (content) dan bahasa (language). Isi dianggap bersifat rohaniah, sedangkan bahasa dianggap bersifat jasmaniah. Keduanya merupakan dwi tunggal yang utuh. Keserasian antara isi dan bahasa bahan bacaan mencerminkan kaindahan serta kemanunggalannya.

\section{B. Teknik Membaca Skimming dan Scanning}

Banyak orang melakukan kegiatan membaca tidak melalui bimbingan khusus membaca cepat sehingga sehingga memunyai kecepatan yang sama dalam membaca. Pembaca yang efisien memunyai kecepatan bermacam-macam. Membaca ibarat berkendaraan adakalanya lambat dan ada waktunya cepat sangat bergantung pada bahan bacaan dan tujuan membaca. Soedarso (1989: 18-19) menguraikan pada umumnya kecepatan membaca dapat dirinci sebagai berikut:

1. Membaca secara skimming dan scanning (kecepatan lebih $1.000 \mathrm{kpm}$ ) digunakan untuk:

a. Mengenal bahan yang akan dibaca,

b. Mencari jawaban atas pertanyaan tertentu

c. Mendapatkan struktur dan organisasi bacaan serta menemukan gagasan umum dari bacaan itu.

2. Membaca dengan kecepatan yang tinggi $(500-800$ $\mathrm{kpm}$ ) digunakan untuk:

a. Membaca bahan-bahan yang mudah telah dikenali

b. Membaca novel ringan untuk mengikuti jalan ceritanya 
3. Membaca secara cepat $(350-500 \mathrm{kpm})$ digunakan untuk:

a. Membaca bacaan yang mudah dalam bentuk deskriptif dan bahan-bahan nonfiksi lain yang bersifat informatif.

b. Membaca fiksi yang agak sulit untuk menikmati keindahan sastranya dan mengantisipasi akhir cerita.

4. Membaca dengan kecepatan rata-rata $(250-350 \mathrm{kpm})$ digunakan untuk:

a. Membaca fiksi yang kompleks untuk analisis watak serta jalan ceritanya,

b. Membaca nonfiksi yang agak sulit, untuk mendapatkan detail, mencari hubungan, atau membuat evaluasi ide penulis

5. Membaca lambat $(100-125 \mathrm{kpm})$ digunakan untuk:

a. Mempelajarai bahan-bahan yang sulit dan untuk menguasai isinya,

b. Menguasai bahan-bahan ilmiah yang sulit dan bersifat teknik,

c. Membuat analisis bahan-bahan bernilai sastra klasik.

6. Memecahkan persoalan yang ditunjuk dengan bacaan yang bersifat instruksional (pedoman)

\section{Usaha dan Potensi Membaca}

Tidak ada hubungan antara latar belakang pendidikan dan kemampuan membaca. Namun, ada korelasi kuat antara kecerdasan dan potensi membaca. Jadi, siapa saja bisa dapat membaca cepat. Mereka dapat membaca semua bahan yang mudah dengan cepat. Hanya karena kebiasaan saja akhirnya kita berlambat-lambat dalam membaca.

Cara menghindari kebiasaan lambat membaca sangat tergantung pada usaha kita. Usaha tersebut dapat ditempuh dengan cara sebagai berikut: 
1. Semua hambatan fisik (seperti, membaca dengan bersuara, dengan gerakan bibir, dan kata demi kata) harus disingkirkan.

2. Kita harus benar-benar menyadari dan mau untuk membaca lebih cepat, menyerbu bahan bacaan dan agresif untuk cepat menyelesaikan bahan bacaan.

3. Kita harus memaksa diri (dipaksa, didorong, dianjurkan, seperti diinstruksikan kalau kita mengikuti latihan membaca cepat) untuk dapat menambah kecepatan dalam membaca sehingga menjadi kebiasaan baru dalam keseharian, yaitu cepat membaca dan menyelesaikan bacaan itu. Hal itu dimaksudkan untuk mendobrak kebiasaan lambat itu.

Keterampilan dasar, seperti gerakan mata, membaca frase, mengenal kata-kata kunci berguna untuk menambah kecepatan membaca, baik untuk fiksi maupun nonfiksi. Skimming dan scanning serta keterampilan mengorganisasi bahan merupakan keterampilan yang harus dikuasai untuk membaca nonfiksi. Skimming dan scanning dapat menjadi teknik yang tepat tuntuk mengatur kecepatan membaca sesuai dengan kebutuhan, terutama untuk nonfiksi sehingga kita tidak dikuasai oleh bahan, tetapi kitalah yang menguasainya sesuai keperluan kita.

\section{Skimming: Cara Membaca Efesien}

Soedarso (1989: 88) skimming adalah tindakan untuk mengambil inti atau sari dari suatu hal. Oleh karena itu, skimming bacaan berarti mencari hal-hal yang penting dari bacaan itu. Ide pokok yang penting dalam bahan bacaan tidak selalu berada di permukaan (awal), biasanya ada di tengah, atau di dasar (bagian akhir). Pengertian yang sesungguhnya skimming adalah suatu keterampilan membaca yang diatur secara sistematis untuk memperoleh hasil yang efesien, untuk berbagai tujuan, seperti untuk mengenali topik bacaan, untuk 
mengetahui pendapat orang (opini), untuk mendapatkan bagian penting yang diperlukan tanpa membaca seluruhnya, untuk mengetahui organisasi penulisan, dan untuk penyegaran apa yang pernah dibaca.

\section{Scanning: Cepat Menemukan Informasi}

Soedarso (1989: 89) scanning adalah suatu teknik membaca untuk mendapatkan suatu informasi tanpa membaca yang lain-lain. Jadi, langsung ke masalah dicari, yaitu fakta khusus dan informasi tertentu. Usaha untuk menemukan yang dicari harus cepat dilakukan dan akurat (100\% benar). Dalam sehari-hari scanning digunakan, antara lain untuk:
a. Mencari nomor telpon
b. Mencari kata pada kamus
c. Mencari entri pada indeks
d. Mencari angka-angka statistik
e. Melihat acara siaran TV,
f. Melihat daftar perjalanan, dan
g. Mencari judul berita atau informasi di internet (website)

\section{Membaca tulisan ilmiah \\ 1. Membaca artikel ilmiah}

Membaca tulisan/artikel ilmiah berbeda dengan membaca jenis tulisan lain karena jenis informasinya yang berbeda. Tulisan ilmiah biasanya berisi informasi yang merupakan hasil penelitian. Ini berbeda dengan jenis tulisan lain yang informasinya bisa berupa pendapat dan kesan pribadi yang belum dibuktikan melalui penelitian dan prosedur ilmiah. Berikut adalah beberapa hal yang mungkin perlu diperhatikan dalam membaca tulisan/artikel ilmiah:

a. Menggali tesis/pernyataan masalah 
Tulisan/artikel ilmiah biasanya mempunyai tesis atau pernyataan umum tentang masalah yang dibahas. Sebuah tesis biasanya diungkapkan dengan sebuah kalimat dan menilai apakah penulisannya berhasil atau tidak dalam membahas atau memecahkan masalah yang diajukan.

b. Meringkas butir-butir penting setiap artikel

Meringkas butir-butir penting setiap artikel yang kit abaca perlu dilakukan karena ringkasan itu bisa dikembangkan untuk mendukung pernyataan yang kita buat. Dengan adanya ringkasan, kita juga tidak perlu lagi membaca artikel secara keseluruhan kalau kita memerlukan informasi dari artikel yang bersangkutan.

c. Menyetir konsep-konsep penting (pandangan ahli, hasil penelitian,dan teori)

Menyetir konsep-konsep penting dari tulisan ilmiah perlu dilakukan untuk mendukung butir-butir penting pada tesis tulisan kita. Dengan memahmi konsepkonsep penting dari sebuah tulisan ilmiah, kita juga dapat lebih memahami konsep-konsep yang akan kita kembangkan dalam tulisan kita.

d. Menentukan bagian yang akan dikutip Mengutip pendapat orang lain merupakan kegiatan yang sering kita lakukan dalam menulis. Dalam mengutip bagian dari sebuah tulisan ilmiah,kita juga perlu memperhatikan relevansi bagian tersebut dengan tulisan kita. Butiran-butir yang di anggap tidak relevan tidak perlu di kutip.

e. Menentukan implikasi dari bagian/sumber yang di kutip Dalam mengutip bagian dari sebuah artikel, kita perlu menyadari implikasinya, apakah kutipan itu mendukung gagasan yang akan kita kembangkan dalam tulisan atau sebaliknya? 
f. Menentukan posisi penulis sebagai pengutip.

Dalam mengutip pernyataan yang ada sebuah artikel, kita perlu secara jelas meletakkan posisi kita. Apakah kita bersikap netral, menyetujui, atau tidak menyetujiu pernyataan yang kita kutip?

\section{Membaca Kritis Artikel Populer}

Tulisan yang kita buat dapat memanfaat informasi dari tulisan /artikel popular.Kegiatan membaca kritis tulisan popular sedikit berbeda dengan membaca kritis tulisan ilmiah karna kedua jenis tulisan tersebut mempunyai sifat yang berbeda.

a. Mengenali persoalan utama atau isu yang dibahas

b. Biasanya isu yang dibahas dalan tulisan popular berkaitan dengan masalah sosial yang sedang diminati masyarakat.

c. Menentukan signifikasi/relenfansi isu dengan tulisan yang akan dihasilkan.

d. Isu yang dibicarakan dlam sebuah tulisan mungkin tidak mempunyai relevansi tuisanyang akan dibuat. Kita harus menghubungkan relevansi isi tulisan yang dibaca dengan isu tuisan yang kita hasilkan.

e. Manfaatkan isu artikel popular untuk bahan/ inspirasi dalam menulis.

f. Isu artikel popular biasanya membahas tentang masalah sosial sehingga lebih menarik disbanding isu artikel ilmiah.

g. Membedakan isi artikel popular dengan isi artikel ilmiah dan buku ilmiah

h. Artikel popular biasanya berisi pembahasan tentang sebuah isu yang sedang diminati masyarakat. Peranan teori dan data sangat penting dalam artikel dan buku ilmiah. 


\section{Membaca kritis buku ilmiah}

Buku ilmiah pada dasarnya sama dengan artikel ilmiah, hanya saja buku ilmiah memuat uraian atau pembahasan yang lebih panjang dan rinci tentang suatu isu ilmiah.

a. Memanfaatkan indeksi untuk menemukan konsep penting

b. Indeksi sangat membantu pembaca untuk mencari dengan cepat pembahasan atau penjelasan konsepkonsep tersebut dalam buku.

c. Menentukan konsep-konsep penting (pandangan ahli, hasil penelitian dan teori) untuk bahan menulis

d. Pengenalan dan pemahaman konsep-konsep yang penting ini juga akan menambah kedalaman dan kekritisan tulisan kita.

e. Menentukan dan menandai bagian-bagian yang dikutip

f. Bagian-bagian ini mungkin akan diacu dan dikutip dalam tulisan kita. Artinya, setiap kutipan ditulis nama penulis, tahun, dan halaman yang di kutip

g. Menentukan implikasi dari bagian/ sumber yang dikutip

h. Dalam mengutip bagian dari sebuah buku kita perlu memahami implikasinya. Kita harus mampu menghubungkan relevansi bagian yang kita kutip dengan isu tulisan yang akan kita hasilkan.tulisan yang dikutip harus dipertimbangkan mengenai implikasinya.

i. Menentukan posisi penulis sebagai pengutip

j. Dalam mengutip pernyataan yang ada dalam sebuah artikel kita perlu secara jelas meletakkan posisi kita, setiap pandangan yang dikutip, seseorang yang menggunakan kutipan itu dalam tulisannya perlu memberikan suatu kesimpulan dan pendapat sendiri mengenai konsep yang ditawarkan. 


\section{Membaca Kritis Bahan-bahan yang Tersaji dalam Jaringan Internet untuk Menulis}

Bahan- bahan yang tersedia dalam jaringan internet bisa dimanfaatkan untuk bahan tulisan kita. Mengingat banyak informasi yang dapat diakses dari internet.

a. Kiat praktis mencari dan menemukan bahan-bahan dalam jaringan internet.

Banyak organisasi atau perorangan atau website yang berkaitan dengan bidang tertentu dari website ini kita bisa mencari bahan-bahan yang kita perlukan untuk tulisan kita. Contoh, Alamat situs http//www.its.ac.id/berita.php?

b. Memilih dan mengevaluasi bahan-bahan dalam jaringan internet untuk bahan menulis

Tidak semua bahan yang kia dapatkan dari internet berguna atau relevan untuk tulisan kita. Artinya bahanbahan yang ditemukan di internet bermanfaat bagi tulisan kita.misalnya, ingin menulis mengenai pendidikan masa kini, tentu mencari bahan yang berkaitan dengan pendidikan masa kini.

c. Menentukan isi atau gagasan penting dalam bahanbahan yang tersedia dalam jaringan internet

d. Untuk menemukan gagasan-gagasan penting, langkah-langkah yang harus dilakukan:

1) Membaca bacaan secara keseluruhan

2) Mencari letak pokok-pokok bacaan tersebut

3) Menentukan apakah paragraph dalam bacaan tersebut bersifat deduktif atau induktif ataukah bersifat paragraf campuran.

4) Jika paragraph tersebut adalah paragraf dedukitif berarti gagasa utamanya berada di awal paragraf tetapi kalau paragraf itu 
merupakan paragraf induktif berarti gagasan utamanya berada pada akhir paragraf.

e. Menentukan secara kritis bahan-bahan dalam jaringan internet untuk menulis.

Orang bisa menerbitkan tulisannya dalam internet dengan mudah dan cepat, ini berbeda dari informasi yang kita dapatkan dari buku atau artikel. Untuk tidak menerima begitu saja tulisan yang ada di internet paling tidak yang kita harus lakukan adalah:

1) Membaca secara sepintas bagian-bagian tertentu.

2) Membuat daftar pertanyaan mengenai bahan tersebut.

3) Mengevaluasi

4) Meninjau kembali bacaan tersebut 


\section{BAB VII \\ KETERAMPILAN MENULIS}

\section{A. Menulis Surat}

urat merupakan salah satu produk komunikasi
tulis yang penting. Pesan-pesan praktis berupa
kabar atau berita tertulis umumnya disampaikan orang melalui surat. Kiranya keunggulan surat yang tak dimiliki oleh alat komunikasi lisan, yaitu bukti berupa tulisan "hitam di atas putih" mengakibatkan orang harus memakai surat sebagai alat komunikasi.

Suatu karangan formal, terutama karangan nonfiksi seperti surat, bahasanya harus jelas, lugas, dan umum (memasyarakat). Selain ketiga syarat utama itu, penulis surat hendaknya juga memperhatikan pemakaian kata-kata baku, pemakaian ungkapan tetap, dan pemakaian ejaan secara benar. Berikut ini permasalahan tersebut akan dibahas secara ringkas satu per satu.Salah satu keterampilan mengarang yang sangat perlu dikuasai adalah menulis surat. Dalam kehidupan sehari-hari kita pasti memerlukan surat. Surat merupakan produk komunikasi tulis yang paling banyak dibuat oleh perseorangan, lebih-lebih oleh suatu organisasi. Dari segi pemakaiannya surat dapat dibedakan atas empat macam, yaitu (1) surat pribadi, (2) surat dinas pemerintah, (3) surat bisnis, dan (4) surat sosial kemasyarakatan.

Surat pada dasarnya merupakan sarana komunikasi tertulis dari satu pihak kepada pihak yang lain. Dalam komunikasi itu terkandung informasi tertentu yang ingin disampaikan. Informasi itu dapat berupa pemberitahuan, perintah, tugas, permintaan, teguran, peringatan, peng- 
hargaan, panggilan, perjanjian, laporan, penawaran, pesanan, pengantar, putusan, dan sebagainya.

Berkenaan dengan hal-hal tersebut di atas surat mempunyai kelebihan karena memiliki fungsi sebagai berikut :

a. Surat sebagai utusan atau wakil penulis/ instansi pengirimnya untuk berhadapan dengan pribadi, kelompok, atau organisasi lain.

b. Surat sebagai dasar atau pedoman untuk bekerja, misalnya surat keputusan dan surat tugas atau instruksi tentang juklak.

c. Surat sebagai bukti tertulis yang otentik hitam di atas putih yang memiliki kekuatan hukum atau yuridis, misalnya surat jual beli, surat wakaf atau pembagian warisan.

d. Surat sebagai alat pengingat atau arsip jika sewaktu-waktu diperlukan.

e. Surat sebagai dokumen historis yang memiliki nilai kesejarahan, misalnya untuk menelusuri peristiwa penting masa lalu atau memuat tentang perkembangan dan perubahan suatu organisasi.

f. Surat sebagai jaminan keamanan, misalnya surat jalan.

1. Langkah-Langkah Penyusunan Surat

Penyusunan surat yang baik bukan sekedar merangkaikan kalimat demi kalimat, melainkan memerlukan kriteria tertentu agar surat yang disusun tampak menarik, efektif dan mudah dipahami. Oleh karena itu, pengonsep atau penulis surat perlu memperhatikan langkah-langkah penyusunan surat sebagai berikut.

a. Sebelum mulai menulis surat, perlu ditetapkan dan dirumuskan terlebih dahulu permasalahan yang akan disampaikan di dalam surat itu. 
b. Permasalahan itu disusun menurut urutan yang telah ditetapkan, kemudian diuraikan secara sistematis melalui kalimat demi kalimat.

c. Kalau diperlukan, uraian itu dapat dilengkapi dengan sejumlah data yang relevan

d. Setiap pokok persoalan hendaknya disusun dalam sebuah paragraf yang jelas.

e. Setelah selesai ditulis, surat itu hendaknya diperiksa kembali untuk mengetahui apakah masalah yang akan disampaikan sudah tuntas atau belum.

f. Jika masih ada masalah yang terlupakan, hendaknya masalah itu segera disisipkan. Demikian pula jika ada penggunaan kalimat atau kata yang kurang baik atau penggunaan tanda baca kurang tepat segera diperbaiki.

g. Jika semuanya telah lengkap dan dianggap memadai, barulah konsep itu diketik dengan rapi.

h. Sebelum ditandatangani, surat yang telah diketik rapi perlu diperiksa secara teliti sekali lagi.

\section{Bahasa dalam Surat Menyurat}

Sebelum menulis surat misalnya, kita harus jelaskan dahulu apa yang kita akan tulis, apa tujuan dan hasil yang diharapkan, serta siapa yang akan dituju oleh surat kita. Ketidakjelasan itu semua akan berakibat pada ketidakjelasan isi surat. Secara umum, bahasa yang digunakan sebagai pengantar dalam surat resmi memiliki ciri berikut :

a. Bahasa yang jelas, yaitu bahasa yang digunakan tidak memberi peluang untuk ditafsirkan berbeda dari maksud penulis surat. 
b. Bahasa yang lugas dan singkat, artinya bahasa yang digunakan langsung tertuju pada persoalan yang ingin dikemukakan. Kelugasan bahasa diwujudkan dalam pemakaian bahasa yang ringkas tetapi padat makna (langsung dan tidak berbelit-belit).

c. Bahasa yang santun, yaitu bahasa yang dipakai menunjukkan rasa hormat dan penghargaan yang wajar dari pengirim terhadap penerima surat. Yang harus diingat, kesantunan berbahasa janganlah berlebihan. Pengiriman surat jangan sampai terlalu merendahkan dirinya dan menyanjungnyanjung sasarannya. Contoh : "... Kami sangat berterima kasih bila Bapak sudi mengabulkan permohonan ini. Atas perhatian dan bantuan Bapak, kami menghaturkan terima kasih yang tak terhingga."

d. Bahasa yang resmi, yaitu bahas yang mengikuti kaidah baku bahasa Indonesia. Kebakuan ragam bahasa itu akan tercermin dalam ejaan, pilihan kata, dan struktur bahasa yang digunakan.

3. Isi Surat

Ditinjau dari segi komposisi, isi surat yang paling ideal adalah yang terdiri atas tiga macam paragraf, yaitu paragraf pembuka, paragraf transisi (isi), dan paragraf penutup. Ketiga jenis paragraf tersebut menjalankan fungsinya tertentu di dalam suatu karangan, termasuk di dalam surat. Memang isi surat dapat dibuat singkat, terdiri atas dua, bahkan satu paragraf. Jika dicermati dalam posisinya sebagai karangan, surat yang demikian itu terasa kurang lengkap atau tidak ideal.

Berdasarkan uraian di atas dapat disimpulkan bahwa struktur surat tidak dapat lepas dari prinsip komposisi. Isi surat biasa atau surat berita sebaiknya 
terdiri atas tiga macam paragraf (pembuka, transisi atau isi, dan penutup) karena masing-masing paragraf mempunyai fungsi tertentu.

a. Paragraf pembuka

Paragraf pembuka pada sebuah surat berfungsi sebagai pengantar bagi pembaca untuk segera mengetahui masalah pokok surat. Di dalam surat resmi, paragraf pembuka harus mengandung masalah pokok surat agar pembaca surat tidak lagi bertanya-tanya atau merasa heran tentang surat yang diterimanya.

b. Paragraf Transisi

Paragraf transisi adalah seluruh paragraf yang terdapat antara paragraf pembuka dan paragraf penutup. Paragraf transisi sangat penting karena di dalamnya terdapat isi surat yang sesungguhnya, yaitu pesan-pesan yang ingin disampaikan oleh pengirim surat. Paragraf transisi dalam isi surat dapat dibangun dengan beberapa cara, yaitu dengan cara repetisi, dengan bantuan frasa transisi, dan dengan bantuan partikel terutama kata sambung.

c. Paragraf Penutup

Paragraf penutup berfungsi memberikan isyarat bahwa uraian masalah pokok surat sudah selesai. Paragraf ini tidak lagi berisi keterangan atau rincian, melainkan lebih merupakan simpulan. Pada bagian ini penulis surat dapat menegaskan sesuatu, mengemukakan harapan atau imbauan, dan mengucapkan terima kasih, bila perlu. Paragraf penutup harus singkat dan tegas serta tidak basa- basi yang berlebihan. Bagian penutup harus selaras dengan misi surat. Bunyi penutup surat disesuaikan dengan maksud surat masing-masing. 


\section{Bentuk Format}

Surat

Bentuk surat adalah pola surat yang ditentukan oleh tata letak atau posisi bagian-bagian surat. Masing-masing bagian- bagian surat diletakkan dalam posisi tertentu sesuai dengan fungsinya. Secara umum, bentuk surat terbagi atas bentuk lurus dan bentuk takuk. Bentuk-bentuk lainnya seperti bentuk lurus penuh, setengah lurus, paragraf menggantung, dan bentuk resmi Indonesia hanyalah variasi dari kedua bentuk surat di atas. Bentuk-bentuk tersebut sebenarnya berasal dari bentuk surat Eropa dan Amerika. Bentuk takuk adalah model surat Eropa lama, bentuk lurus adalah model Amerika, dan bentuk setengah lurus adalah model Eropa baru.

Di antara sekian bentuk surat, yang tampaknya banyak digunakan adalah bentuk lurus, setengah lurus, dan bentuk resmi Indonesia. Adapun bentuk lurus penuh, takuk, dan alinea menggantung tampaknya belum banyak digunakan. 


\section{a. Bentuk Lurus Penuh}

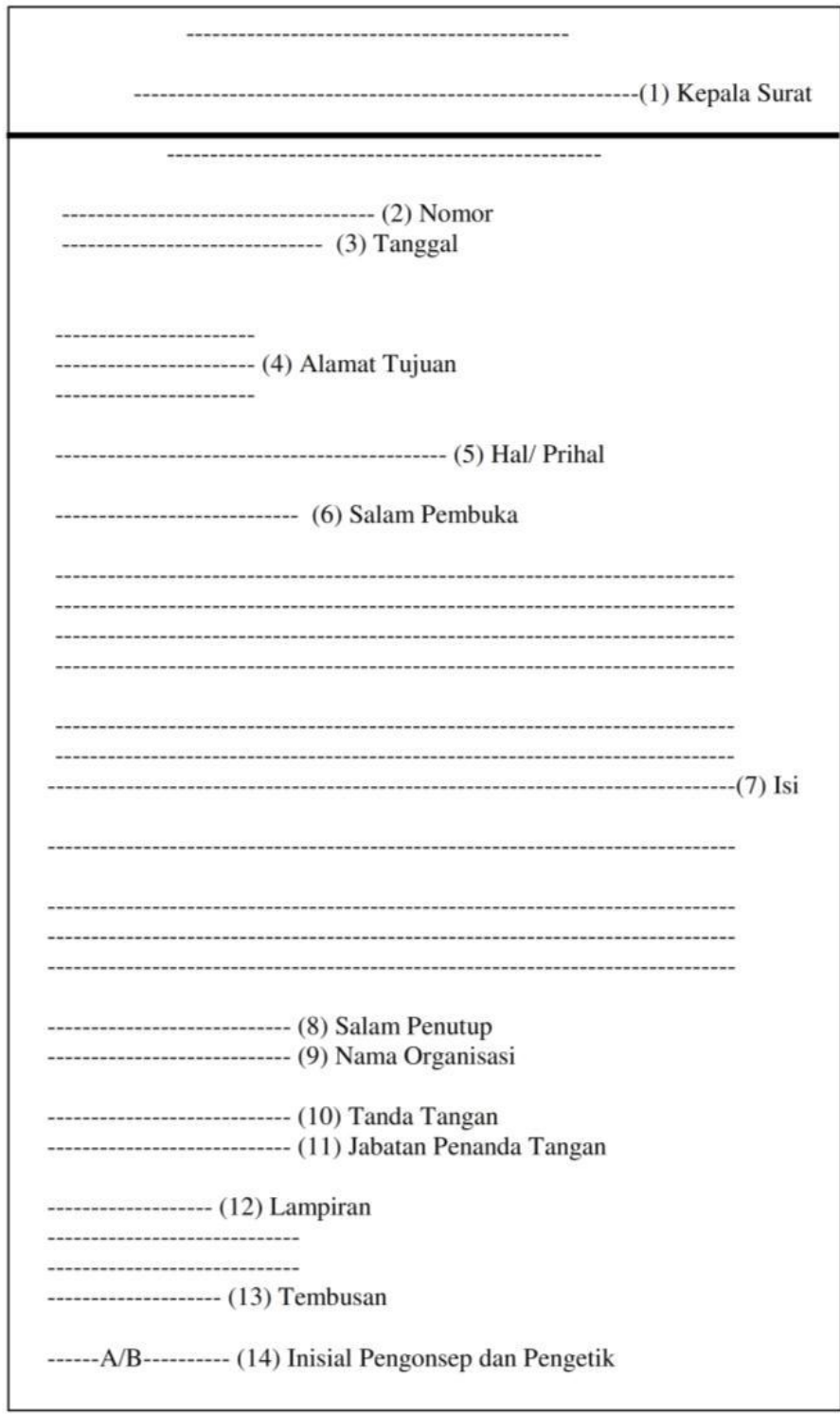




\section{b. Bentuk Lurus}

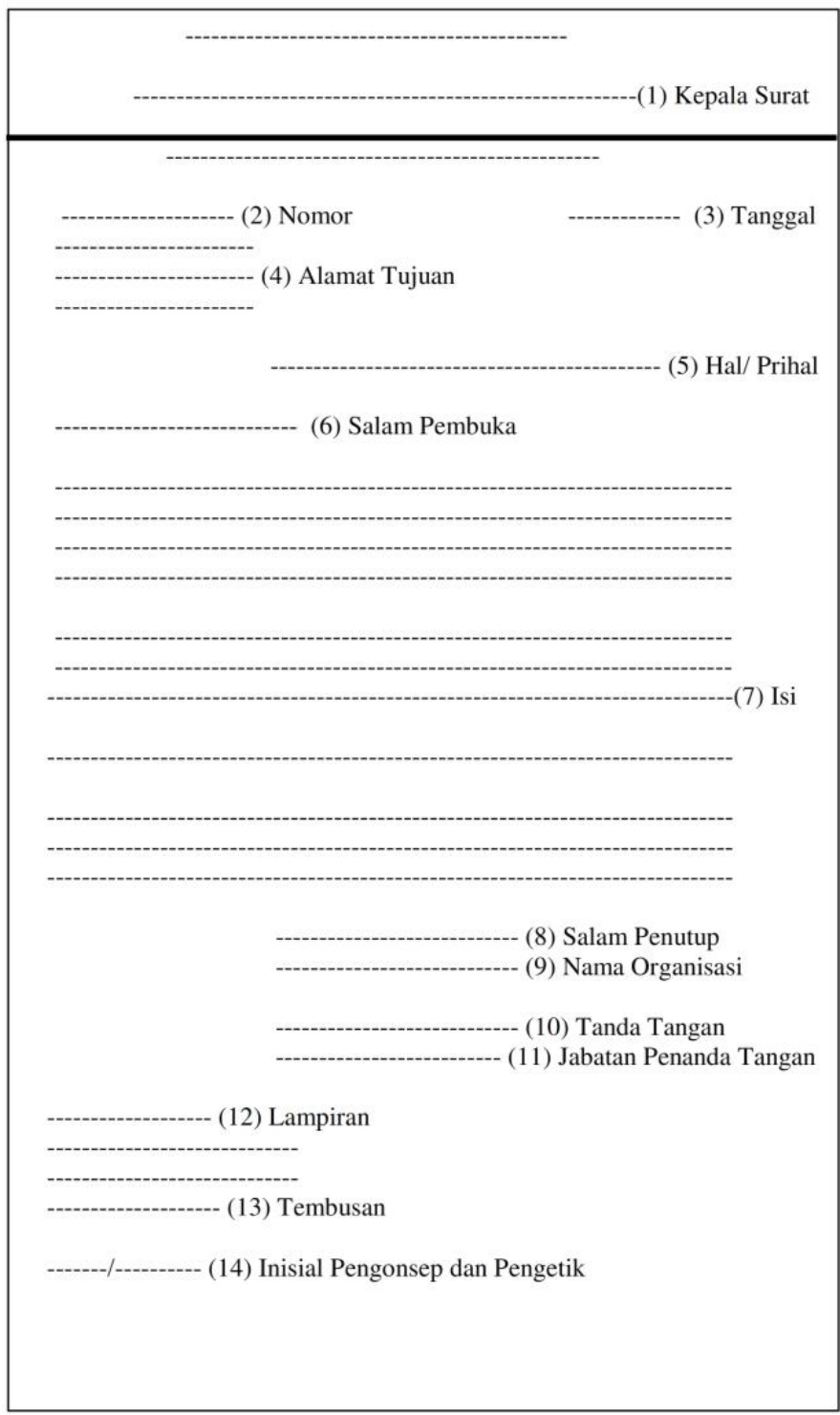




\section{c. Bentuk Takuk}

(1) Kepala Surat

(2) Nomor

(3) Tanggal

(4) Alamat Tujuan

(5) Hal/ Prihal

(6) Salam Pembuka

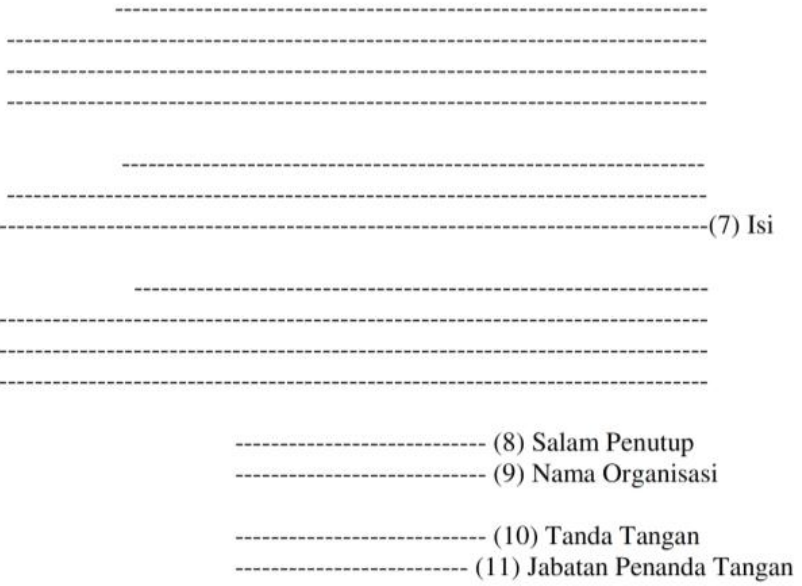

(12) Lampiran

(13) Tembusan

(14) Inisial Pengonsep dan Pengetik 


\section{d. Bentuk Paragraf Menggantung}

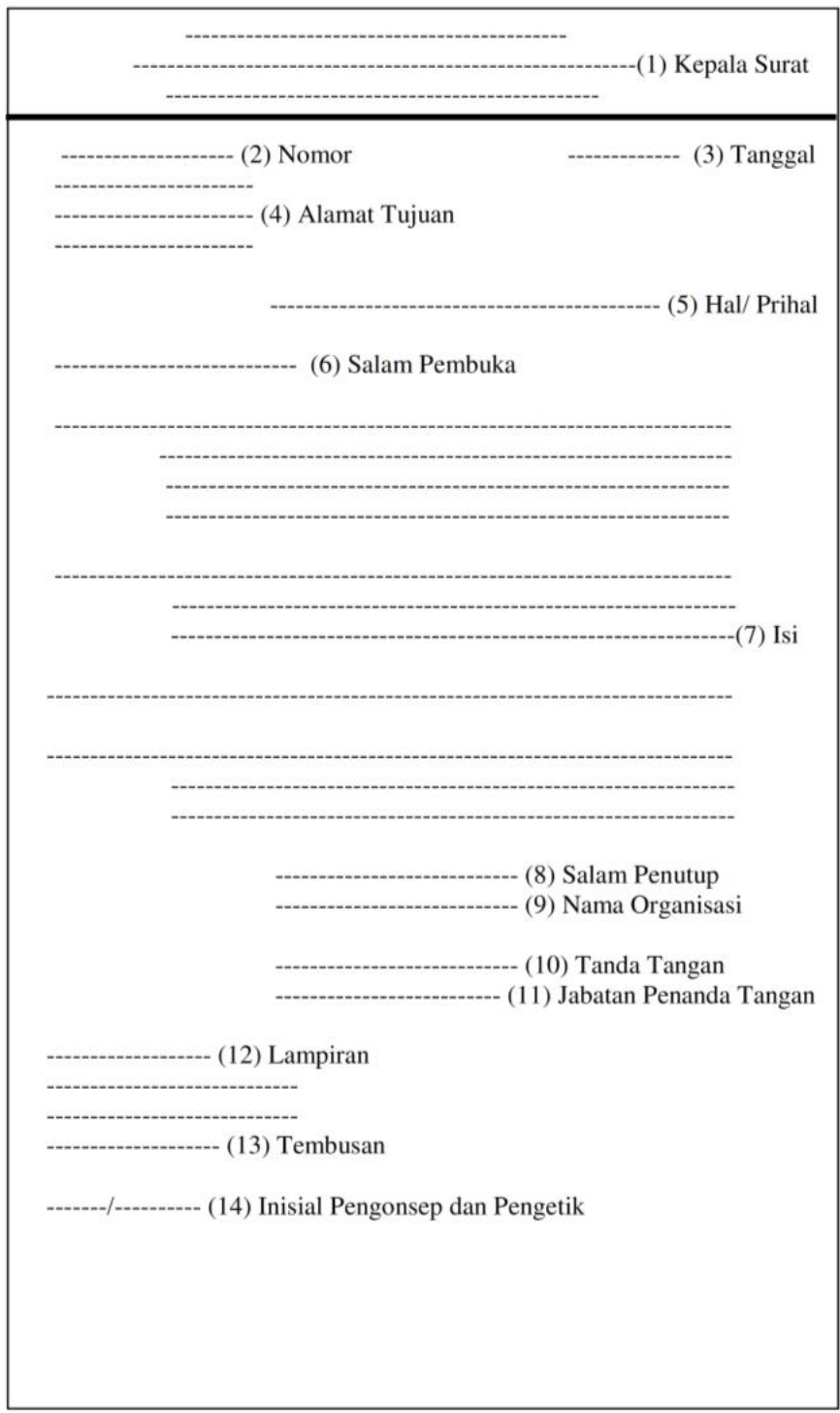




\section{e. Bentuk Setengah Lurus}

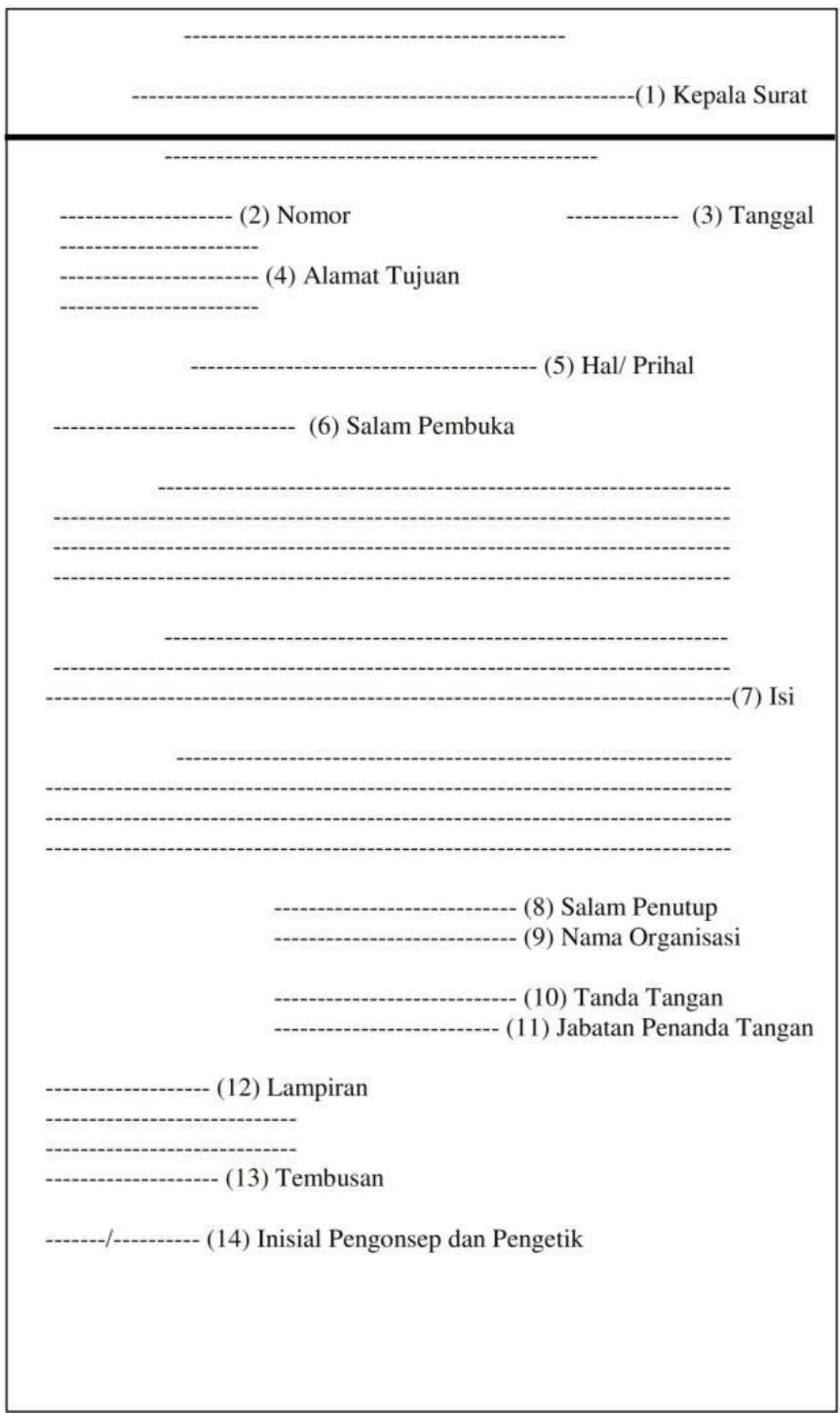




\section{f. Bentuk Surat Resmi Indonesia Lama}

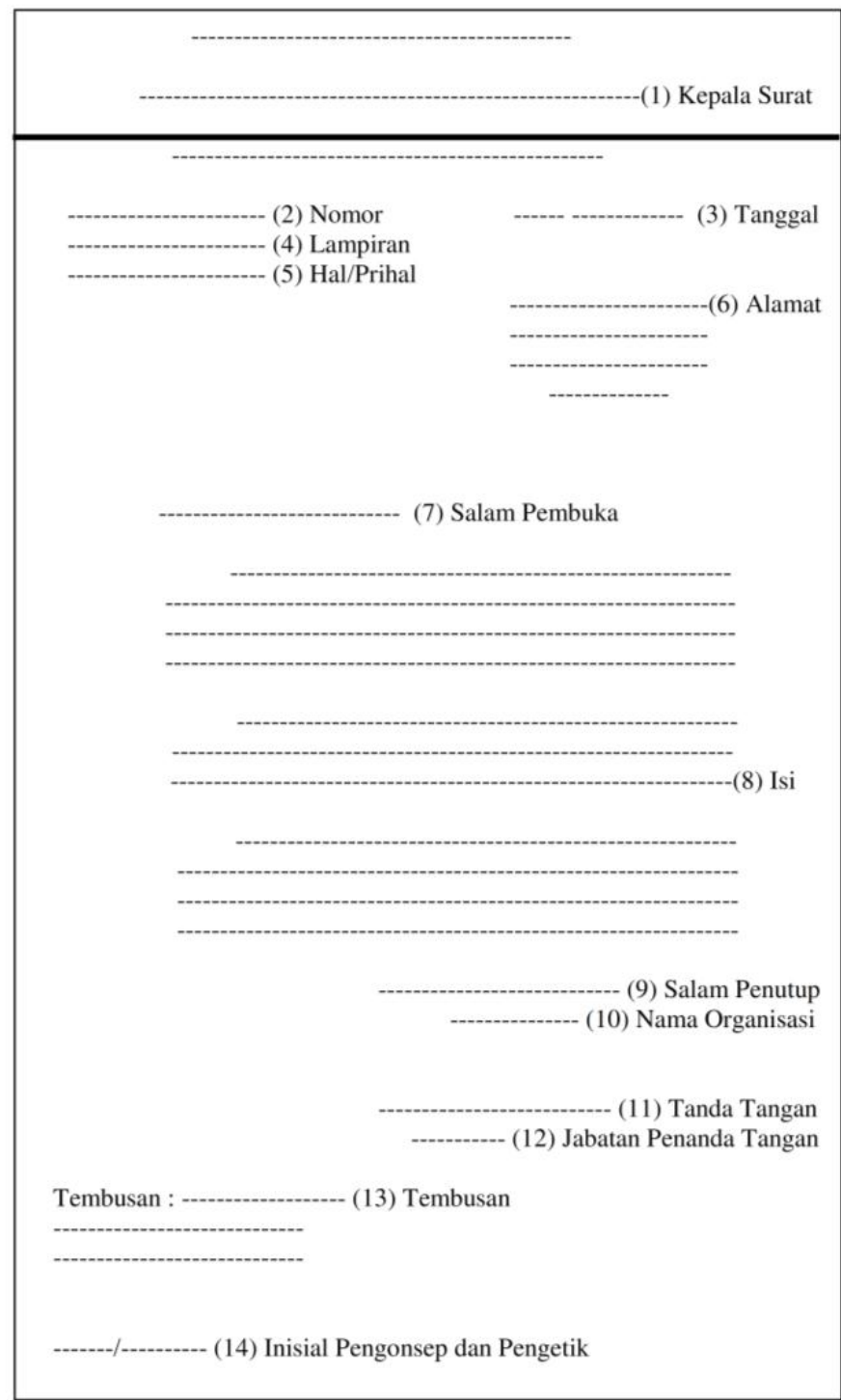




\section{g. Bentuk Surat Resmi Indonesia Baru}

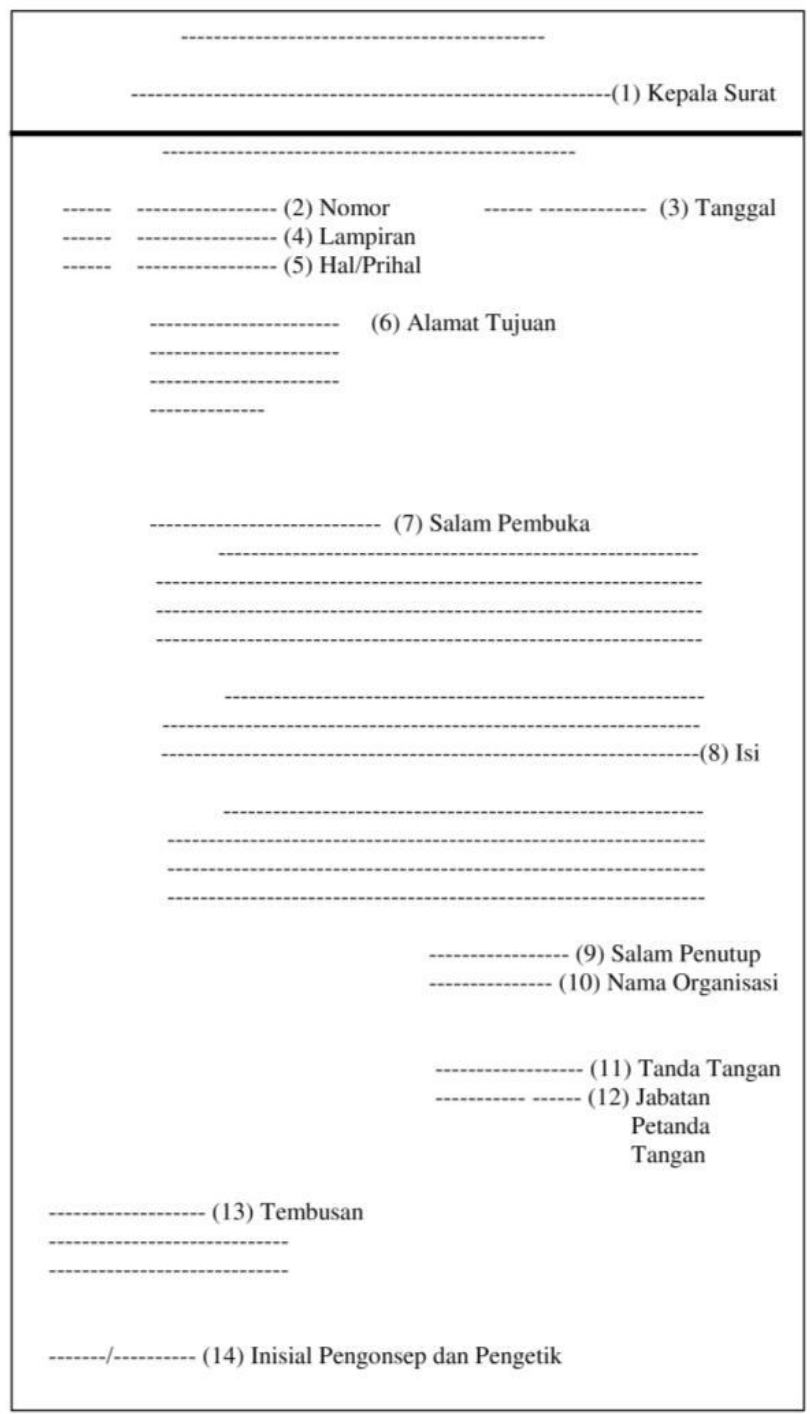




\section{Bagian Bagian Surat}

Salah satu hal yang sangat khas, yang membedakan surat dari bentuk karangan lainnya adalah bagian-bagian surat yang disusun dalam posisi tertentu sesuai dengan bentuk surat yang digunakan. Masingmasing bagian memiliki fungsi. Jumlah bagian surat berbeda-beda, tergantung jenisnya. Pada surat pribadi misalnya, hanya terdapat bagian-bagian yang dianggap penting saja. Keberadaan bagian-bagian itu bervariasi antara satu orang dengan yang lainnya. Sebaliknya, dalam surat resmi atau surat dinas, bagian-bagian itu biasanya relatif lebih lengkap dan seragam.

Surat dinas biasanya terdiri atas :

1. kepala surat,

2. nomor surat,

3. tanggal, bulan, dan tahun surat,

4. lampiran,

5. hal atau perihal,

6. alamat surat (alamat dalam),

7. salam pembuka,

8. isi surat,

9. salam penutup,

10. jabatan penulis surat,

11. tanda tangan,

12. nama terang,

13. nomor induk pegawai/NIP bagi pegawai pemerintah,

14. cap dinas atau cap jabatan,

15. tembusan, dan

16. inisial. 


\section{B. Menulis Makalah}

Makalah lazimnya, dibuat melalui kedua cara berpikir, tetapi tidak menjadi soal jika menggunakan satu dari dua cara berpikir tersebut. Apakah hanya menggunakan sajian berpikir berbasis deduktif, atau memilih sajian berpikir induktif saja. Hal yang terpenting adalah makalah tidak ditulis berdasarkan opini belaka.

Penulisan makalah dalam tradisi akademik adalah karya ilmuwan atau mahasiswa yang sifatnya paling "soft" dari jenis karya ilmiah lainnya. Namun, sering bobot akademik atau bahasan keilmuannya lebih tinggi. Misalnya, makalah yang dibuat oleh ilmuwan dibanding skripsi mahasiswa. Makalah yang dibuat oleh mahasiswa diperuntukkan memenuhi tugas perkuliahan. Oleh karena itu, aturannya tidak seketad makalah para ahli. Makalah biasa disusun berdasarkan hasil bacaan tanpa menandemnya dengan kenyataan lapangan. Makalah lazim dibuat berdasarkan kenyataan. Kemudian, ditandemkan dengan kajian teoretis dengan menggabungkan cara berpikir deduktif-induktif atau sebaliknya. Makalah adalah karya tulis ilmiah yang paling sederhana.

Makalah adalah karya ilmiah yang memuat topik tertentu yang disajikan pada forum ilmiah atau disusun untuk kepentingan tertentu, misalnya tugas kuliah. Makalah dapat dihasilkan dari sebuah penelitian, hasil pemikiran dan kajian literatur yang memadai. Makalah harus disusun berdasarkan sebuah topik keilmuan tertentu.

Karateristik sebuah makalah di antaranya:

1. hasil kajian pustaka atau laporan pelaksanaan kegiatan lapangan harus sesuai dengan cakupan permasalahan suatu bidang keilmuan,

2. kemampuan penulis untuk memahami tentang permasalahan teoretis yang dikaji dan menerapkan prosedur, 
prinsip, dan teori yang berhubungan dengan bidang keilmuan,

3. kemampuan penulis dalam memahami isi dari berbagai sumber yang digunakan, dan

4. kemampuan penulis dalam meramu berbagai sumber informasi dalam satu kesatuan sintesis yang utuh.

Dalam konteks perkuliahan seminar, symposium, dan kehidupan ilmiah lainnya, seorang sering diminta pandanganya atau dituntut untuk menunjukan kinerja akademiknya melalui sebuah paparan yang berkaitan dengan keahliannya. Agar paparan itu memberikan dampak yang luas, penyaji diminta menulis makalah atau kertas kerja.

Mahasiswa yang duduk di bangku perkuliahan hendaknya memiliki kemampuan menyiapkan dan menyajikan makalah sejak dini agar pihak lain tahu bahwa dirinya memiliki kemampuan dan keahlian tertentu. Sebelum seseorang bekerja atau melanjutkan studi, pihak perusahaan atau sekolah lazim meminta kepadanya untuk melampirkan karya terbaiknya atau memaparkan keahliannya di depan sekelompok orang. Bagaimana mungkin orang lain mengetahui bahwa seseorang ahli, jika tidak mampu menunjukan keahliannya, baik secara tertulis maupun secara lisan. Hal inilah pentingnya keterampilan menulis makalah.

Menulis makalah merupakan tahapan lanjutan dari kegiatan menulis artikel ilmiah. Jika seseorang telah terbiasa menulis artikel atau karangan nonfiksi lainnya dalam bentuk sederhana, dia tidak akan menjumpai kesulitan berarti dalam menyusun bahasa yang lebih luas dari makalah, jenis makalah, sistematik makalah, dan menulis makalah.

\section{Pengertian makalah}

Karya ilmiah yang memuat pemikiran tertentu tentang suatu masalah atau topik disebut makalah. Makalah berisikan analisis yang logis, runtut, sistematis, dan objektif. 
Biasanya makalah dibuat oleh mahasiswa untuk memenuhi tugas dari dosen. Selain itu, makalah ditulis oleh penulis untuk kegiatan ilmiah, seperti seminar, lokakarya, dan sebagainya. Menurut Arifin (2003: 3) kertas kerja, seperti halnya makalah adalah karya tulis ilmiah yang menyajikan sesuatu berdasarkan data di lapangan yang bersifat empiris-objektif.

Makalah adalah karya tulis ilmiah mengenai suatu topik tertentu yang tercakup dengan ruang klingkup perkuliahan atau yang berkaitan dengan suatu tema seminar, simposium, diskusi atau kegiatan ilmiah lainnya. Makalah merupakan salah satu syarat untuk menyelesaikan perkuliahan.

Makalah sering juga disebut paper atau kertas kerja. Secara spesifik kedua jens tulisan ini hampir sama, tetapi memiliki nuansa perbedaan. Makalah adalah karya tulis ilmiah yang menyajikan suatu masalah yang pembahasannya berdasarkan data di lapangan yang bersifat empiris-objektif. Jenis karya tulis makalah menyajikan masalah melalui proses berpikir deduktif dan induktif. Makalah disusun, biasanya untuk melengkapi tugas-tugas ujian mata kuliah tertentu atau untuk memberikan saran pemecahan tentang masalah secara ilmiah. Makalah menggunakan bahasa yang lugas dan tegas. Jika dilihat bentuknya, makalah adalah karya tulis ilmiah yang paling sederhana di antara karya tulis ilmiah yang lain.

Jenis karya tulis kertas kerja, seperti halnya makalah adalah juga karya tulis ilmiah yang menyajikan sesuatu berdasarkan data di lapangan yang bersifat empiris-objektif. Analisis dalam kertas kerja lebih serius daripada analisis dalam makalah. Kertas kerja ditulis untuk disajikan dalam suatu seminar atau lokakarya. 
Makalah ditulis untuk berbagai fungsi, di antaranya untuk memenuhi tugas yang dipersyaratkan dalam mata kuliah tertentu, berfungsi menjelaskan suatu kebijakan, dan berfungsi menginformasikan suatu temuan. Pengertian dan fungsi di atas berimplikasi terhadap keragaman dan jenis makalah, seperti dikemukakan berikut ini.

\section{Jenis makalah}

Secara umum, baik dalam kegiatan akademik maupun nonakademik, dikenal dua jenis makalah, yaitu makalah biasa (common paper) dan makalah posisi (position paper) (UPI, dalam Tang dkk., 2008: 103). Makalah biasa dibuat mahasiswa untuk menunjukan pemahamannya terhadap permasalahan yang yang dibahas. Dalam makalah ini secara deskriptif, mahasiswa mengemukakan berbagai aliran atau pandangan tentang masalah yang dikaji. Dia juga memberikan pendapat baik berupa kritik atau saran mengenai aliran atau pendapat yang dikemukakan oleh orang lain. Mahasiswa tidak perlu memihak salah satu aliran atau pendapat tersebut dan berargumentasi mempertahankan pendapat yang diikutinya.

Makalah juga biasa dapat ditulis seseorang untuk mendeskripsikan suatu kebijakan, gagasan, atau temuan kepada khalayak. Sebagai contoh, seorang mahasiswa aktifis dapat mengemukakan gagasannya tentang metode pengolahan sampah, atau seorang pejabat memaparkan tentang kebijakannya dalam meningkatkan kualitas pendidikan dasar di daerahnya.

Dalam makalah posisi, mahasiswa dituntut untuk menunjukan posisi toretisnya dalam suatu kajian. Untuk makalah jenis ini, tidak hanya diminta menunjukan penguasaan mengenai suatu teori atau pandangan tertentu, tetapi juga dipersyaratkan untuk menunjukan di 
pihak mana dia berdiri beserta alasan yang didukung oleh teori-teori atau data yang relevan.

Untuk dapat membuat makalah posisi, mahasiswa diharuskan untuk mempelajari sumber tentang aliran yang pandangannya berbeda-beda dan bahkan, sangat bertentangan sehingga dari hasil kajian tersebut dapat dibuat kesimpulan sekaligus secara teoretis dapat memosisikan diri dalam suatu kajian masalah. Jenis makalah ini tidak hanya menunjukkan penguasaan pengetahuan, tetapi juga menunjukkan posisi penulis yang paling tepat dengan didukung teori dan bukti-bukti yang relevan. Dari bahasan tersebut, mungkin mahasiswa memihak salah satu aliran, tetapi mungkin pula dia membuat suatu jenis sintesis dari berbagai pendapat yang ada. Jadi, kemampuan analisis dan evaluasi sangat diperlukan untuk membuat makalah posisi.

Pada umumnya makalah biasa diwajibkan pada mahasiswa S-1, sedangkan makalah posisi diwajibkan pada mahasiswa pascasarjana. Di samping itu, makalah posisi juga ditulis untuk didiskusikan dalam sebuah forum seminar yang menyoroti gagasan, kabijakan atau temuan seseorang.

\section{Sistematika makalah}

Makalah biasanya disusun dengan sistematika sebagai berikut: (1) judul, (2) abstrak, (3) pendahuluan, (4) isi dan pembahasan, (5) simpulan, dan (6) daftar pustaka. Makalah ilmiah yang sering disusun mahasiswa disebut dengan istilah tern paper, biasanya disingkat paper. Paper ini merupakan tugas tertulis dalam suatu permasalahan yang sedang aktual di masyarakat. Keenam butir ini dapat diuraikan seperti berikut. 


\section{1) Judul karangan}

Judul dapat dipandang sebagai tanda pengenal karangan dan sekaligus juga kunci utama untuk mengetahui isi karangan. Oleh karena itu, judul harus mencerminkan seluruh isi karangan dan dapat menunjukan fokus serta permasalahan pokok karangan. Judul juga harus disususn secara singkat, artinya judul tidak boleh disajikan dalam bentuk kalimat atau frasa yang panjang, tetapi cukup dalam bentuk ungkapan yang singkat dan padat. Jika tidak dapat dihindari judul yang panjang, Keraf (1984: 129) menyarankan untuk membuat judul utama yang singkat. Kemudian, diberi judul tambahan yang panjang. Judul yang terlalu panjang dapat dipecah menjadi judul utama dan anak judul.

\section{2) Abstrak}

Abstrak atau ringkasan biasanya berisi inti atau sari keseluruhan tulisan, ditulis secara naratif, dan diketik satu spasi serta paling banyak tiga paragraf atau sekitar 150200 kata. Abstrak memuat latar belakang masalah, tujuan, kesimpulan, dan saran yang ditulis secara padat.

\section{3) Pendahuluan}

Bagian pendahuluan terdiri atas latar belakang masalah yang disusun dalam alur pikir yang logis, yang menunjukan kesenjangan antara situasi yang ada dengan situasi yang diharapkan (das sollen dan das sein).

\section{4) Pembahasan}

Bagian ini merupakan inti makalah. Pada bagian ini hendaknya dikemukakan deskripsi tentang subjek studi, analisis permasalahan, dan solusi pemecahannya. Pada bagian ini aspek-aspek yang dipersoalkan pada bagian pendahuluan dikaji dan dianalisis satu demi satu sehingga masalah yang dipersoalkan menjadi jelas kedudukannya dan permasalahnnya. Untuk memperkuat daya analisis, 
penulis hendaknya menggunakan teori, data, atau pandangan ahli.

\section{5) Kesimpulan}

Secara umum kesimpulan berisi hasil dari seluruh pembahasan dan setidaknya berisi jawaban atas semua permasalahan yang dikemukakan dalam pendahuluan. Kesimpulan merupakan ringkasan hasil proses analisis dalam penulisan makalah.

\section{6) Daftar pustaka}

Bagian ini memuat pustaka atau rujukan yang diacuh dalam makalah. Rujukan ini disusun ke bawah menurut abjad nama akhir penulis pertama. Buku dan makalah tidak dibedakan, kecuali penyusunannya dari kiri ke kanan. Untuk buku, teknik penulis daftar pustaka sebagai berikut: Nama penulis, tahun terbit, judul buku, jilid (jika ada), terbitan ke-, nama kota, dan nama penerbit.

\section{Praktik Penulisan Makalah}

Pemahaman terhadap konsep, jenis, dan sistematika makalah tidak menjamin mahasiswa dapat menulis makalah. Oleh karena itu, mahasiswa perlu dilatih sejak dini dalam membuat artikel sederhana. Bahkan, mereka dapat diminta menulis apa yang cenderung mereka senangi, seperti puisi. Setelah kegiatan ini dianggap cukup, barulah mahasiswa diminta untuk "berbelanja" pengetahuan, gagasan, dan teori dari artikel dan buku-buku yang dibacanya. Hasil "belanja" mereka perlu diikuti dengan kegiatan berikutnya, yaitu membuat laporan hasil membaca artikel atau bab dari sebuah buku, seperti yang telah disajikan pada bagian terdahulu.

Sebelum menulis makalah, sebaiknya dibuat jenjang ide. Inti kegiatan ini adalah mengidentifikasi ide pokok dan ide penunjang. Jejaring ide bukan hanya berguna bagi 
penulis, melainkan juga bagi pembaca. Melalui jejaring ide, pembaca dapat mengikuti jalan pikiran penulis sehingga dapat menulis tulisan secara kritis. Untuk mempermudah proses penulisan, jejaring yang diuraikan di bawah ini, dapat disajikan dalam bentuk kerangka karangan.

Alwasilah dalam Tang dkk. (2008) mengemukakan beberapa langkah membuat jejaring ide, seperti berikut ini:

(1) sebelum menulis, siapkan kertas dan alat tulis,

(2) pikirkan ide-ide pokok yang paling penting untuk ditulis,

(3) batasi maksimal lima ide pokok,

(4) tulis ide pokok itu sesingkat mungkin dalam lingkaranlingkaran,

(5) hubungkan lingkaran tersebut dengan garis searah atau dua arah sesuai pemikiran Anda,

(6) gunakan pula garis patah-patah untuk menunjukan hubungan tidak langsung. Visualisasi ide-ide ini sesungguhnya subjektif, bergantung pada penulis, dan

(7) narasikan hubungan antara berbagai lingkaran itu.

\section{Karya Reproduksi Bacaan}

Selain jenis karya ilmiah tersebut di atas, masih ada jenis karya reproduksi, seperti diungkapkan Utorodewo dkk. dalam Wijayanti dkk. (2013: 171-172) untuk dapat menulis ilmiah dibutuhkan kemampuan membaca dan memahami topik yang hendak dibahas dari berbagai sumber bacaan, seperti artikel jurnal, buku, termasuk tugas akhir akademik (skripsi, tesis, dan disertasi). Namun, bukan berarti Anda harus menggunakan semua isi dalam sumber bacaan tersebut. Dalam proses ini dibutuhkan kemampuan menyarikan sumber bacaan dan menyajikan dalam bentuk tulisan yang berbeda dari tulisan aslinya. Kegiatan ini disebut mereproduksi bacaan. Kegiatan yang tergolong reproduksi bacaan terdiri atas: menyusun ringkasan, resensi, rangkuman, dan sintesis. 


\section{Ringkasan}

Ringksan adalah cara yang efektif untuk menyajikan karangan yang panjang dalam bentuk singkat. Karena ringkasan bertolak dari penyajian karya asli secara singkat maka ia merupakan keterampilan untuk mengadakan reproduksi. Dalam melakukan kegiatan ringkasan ibarat memotong atau memangkas sebatang pohon sehingga tinggal batang, cabang, dan ranting yang terpenting beserta daundaun yang diperlukan sehingga tampak bahwa esensi pohon masih dipertahankan. Dalam ringkasan keindahan gaya bahasa, ilustrasi serta penjelasan yang terperinci dihilangkan, sedangkan sari karangannya dibiarkan tanpa hiasan. Meskipun demikian, peringkas harus tetap mempertahankan urutan pikiran penulis asli beserta pendekatannya. Karena ringkasan merupakan penyajian singkat dari karangan asli, tetapi tetap mempertahankan urutan isi dan sudut pandang pengarang asli, sedangakan perbandingan bagian atau bab dari karangan asli secara proporsional tetap dipertahankan dalam bentuknya yang singkat.

Prosedur dan etika dalam meringkas, peringkas berbicara berdasarkan suara penulis asli, peringkas tidak boleh memulai ringkasannya dengan kata atau frase, "Dalam tulisannya penulis berkata ... . " atau "Dalam buku ini penulis mengatakan . . . dan sebagainya." Peringkas langsung menyusun ringkasan bacaan dalam rangkaian kalimat, alinea, bagian alinea, seterusnya. Sumber bacaan yang dapat diringkas berupa buku, bab di dalam buku atau artikel, atau skripsi, dan sebagainya (Wijayanti, dkk. 2013: 172).

Beberapa langkah atau prosedur yang dipergunakan untuk membuat ringkasan agar menjadi baik dan teratur, adalah sebagai berikut.

a. Membaca naskah asli, yaitu penulis ringkasan harus membaca naskah asli seluruhnya beberapa kali untuk 
mengetahui kesan umum, maksud pengarang, serta sudut pandang penulis asli. Oleh karena itu, judul dan daftar isi dapat dijadikan pegangan.

b. Mencatat gagasan utama, atau gagasan yang penting dicatat, atau digaris bawahi. Fungsi pencatatan ini adalah memudahkan peringkas meneliti kembali apakah pokok-pokok yang dicatat itu penting atau tidak.

c. Membuat reproduksi bacaan, yaitu sebagai langkah ketiga penulis ringkasan menyusun kembali suatu ringkasan singkat (ringksan) berdasarkan gagasan utama sebagaimana yang dicatat pada langkah kedua di atas. Dalam proses ini digunakan kalimat dan rangkaian gagasan sendiri ke dalam tulisan tanpa menghilangkan kekhasan penulis asli.

d. Ketentuan tambahan, yaitu di samping, ketiga langkah di atas masih ada beberapa ketentuan tambahan yang perlu diperhatikan pada waktu menyusun ringkasan.

1) Gunakan kalimat tunggal, jangan kalimat majemuk.

2) Ringkaslah kalimat menjadi frasa, frasa menjadi kata, gagasan yang paling panjang diganti dengan gagasan sentral saja. Ingat tidak semua kalimat harus dicermati. Bahkan, ada alinea dapat diabaikan pada jenis karangan tertentu.

3) Jika perlu semua keterangan atau kata sifat dibuang. Kalau dipertahankan gunakan untuk menjelaskan gagasan utama.

4) Pertahankan urutan dan susunan gagasan asli. Jangan memasukkan gagasan, komentar, dan interpretasi peringkas ke dalam ringkasan.

5) Buanglah contoh dan penjelasan rinci dan ubalah dialog menjadi dialog tidak langsung, tetapi jangan mengubah pola pikiran penulis asli. 


\section{Ikhtisar}

Baik ringkasan maupun ikhtisar merupakan kegiatan menyusun inti tulisan asli. Ikhtisar adalah rangkuman gagasan yang dianggap penting oleh penyusun ikhtisar yang digali dari bacaan (Utorodewo dkk. dalam Wijayanti dkk. 2013: 176). Dalam penulisan ikhtisar urutan karangan asli tidak perlu dipertahankan, tidak perlu isi seluruh karangan dipertahankan secara poporsional. Penulis ikhtisar langsung mengemukakan pokok atau inti masalah dan problematika pemecahannya. Ilustrasi beberapa bagian atau isi dari beberapa bab dapat dipergunakan sebagai penjelasan inti atau pokok masalah, sedangkan bagian atau bab-bab yang kurang penting dapat diabaikan.

Ikhtisar bercirikan tulisan baru yang mengandung sebagian gagasan dari tulisan asli yang dianggap penting oleh penyusun ikhtisar, tidak mengandung hal baru, pikiran, atau opini dari penyusun ikhtisar. Penyusun ikhtisar menggunakan kata-kata yang disusun dan dipilih sendiri sesuai keinginannya.

Ringkasan dan ikhtisar merupakan istilah yang sering dikacaukan. Pada dasarnya keduanya memiliki perbedaan, seperti yang terdapat pada tabel di bawah ini.

\begin{tabular}{|l|l|l|}
\hline $\begin{array}{c}\text { Unsur } \\
\text { Pembeda }\end{array}$ & \multicolumn{1}{|c|}{ Ringkasan } & \multicolumn{1}{|c|}{ Ikhtisar } \\
\hline Urutan isi & $\begin{array}{l}\text { Tetap } \\
\text { dipertahankan } \\
\text { seperti naskah } \\
\text { asli }\end{array}$ & $\begin{array}{l}\text { Tidak perlu berurutan, } \\
\text { dapat langsung ke inti } \\
\text { atau pokok masalah } \\
\text { dan pemecahannya } \\
\text { atau dari yang } \\
\text { dianggap penting ke } \\
\text { yang kurang penting }\end{array}$ \\
\hline Sudut & Asli dari penulis & Ada unsur gaya \\
\hline
\end{tabular}




\begin{tabular}{|l|l|l|}
\hline pandang & & $\begin{array}{l}\text { personal dari penyusun } \\
\text { ikhtisar }\end{array}$ \\
\hline $\begin{array}{l}\text { Perbandingan } \\
\text { bagian bab }\end{array}$ & $\begin{array}{l}\text { Tetap } \\
\text { dipertahankan } \\
\text { secara } \\
\text { proporsional }\end{array}$ & $\begin{array}{l}\text { Tidak proporsional } \\
\text { prop }\end{array}$ \\
\hline Ilustrasi & tidak perlu & $\begin{array}{l}\text { Dapat diberikan } \\
\text { asalkan mendukung isi }\end{array}$ \\
\hline
\end{tabular}

\section{Resensi}

\section{a. Pengertian}

Suatu jenis tulisan lain yang memunyai titik singgung dengan ringkasan dan ikhtisar adalah resensi. Resensi adalah tulisan atau ulasan mengenai nilai sebuah hasil karya atau buku. Tujuan resensi adalah menyampaikan kepada para pembaca apakah sebuah buku atau hasil karya itu patut mendapat sambutan dari masyarakat atau tidak.

Resensi adalah tulisan dalam bentuk sederhana dengan mengungkapkan kembali isi secara ringkas, mengulas, serta memberikan penilaian terhadap tulisan. Tujuan penulisan resensi pada umumnya menginformasikan hal-hal yang termuat dalam sebuah tulisan secara sekilas kepada pembaca. Resensi akan menjadi petunjuk bagi pembaca untuk memutuskan apakah tulisan tersebut patut dibaca lebih mendalam atau tidak.

Penulisan resensi dalam praktiknya dimanfaatkan sebagai cara memperkenalkan atau mempromosikan bukubuku baru dari penerbit kepada masyarakat umum melalui media cetak. Istilah resensi buku dalam beberapa media cetak disebut timbangan buku, laporan buku, apresiasi buku, bedah buku, rehal, makhtabah, sorotan buku, ulasan buku, berita buku, dan sebagainya. 
Secara teknis dalam menyusun resensi dilakukan kegiatan kombinasi antara menguraikan, meringkas, dan mengkritik secara objektif sebuah buku. Pembaca, selain mengharapkan ringkasan isi buku, juga mengharapkan kritik terhadap mutu dan manfaat buku tersebut.

\section{b. Dasar Resensi}

Ada dua aspek yang menjadi pertimbangan agar peresensi dapat memberikan penilaian secara objektif terhadap buku yang diresensinya. Pertama, peresensi mengetahui sepenuhnya penulis asli. Tujuan ini dapat diketahui dari kata pengantar atau bagian pendahuluan buku. Kedua, peresensi harus menyadari apa maksud dan tujuan menulis resensi itu, peresensi perlu memperhatikan siapa pembacanya, apakah resensi relevan dengan kebutuhan pembaca, bagaimana selera dan tingkat pendidikan pembaca, dan sebagainya. Selanjutnya, pokokpokok yang dapat dijadikan sasaran penilaian sebuah buku atau karya adalah (1) latar belakang, (2) macam atau jenis buku, dan (3) keunggulan buku.

\section{c. Bentuk Resensi}

Resensi berisi semua dasar ide dan kebenaran isi penulis buku. Oleh karena itu, resensi disusun dengan memperhatikan bentuk-bentuk di bawah ini.

1) Ringkasan, yaitu dalam resensi ditulis bentuk ringkasan yang tidak berpihak kepada pribadi, tetapi berdasarkan fakta dan seluruhnya objektif. Persoalan yang dipaparkan dalam isi buku dapat diringkas dalam uraian yang padat dan jelas. Caranya, pilih dan tonjolkan halhal yang terdapat di dalam buku tersebut.

2) Deskripsi buku, yaitu buku dipandang secara keseluruhan dengan mengupas teknik atau gaya penulisan, kebahasaan, hingga substansi buku. 
3) Kritik, yaitu dalam resensi perlu mengkritik penulis buku, dilihat dari kompetensi acuan pustaka yang digunakan hingga metode panyampaiannya.

4) Apresiasi, yaitu apresiasi dikemukakan dengan mengangkat pendapat pribadi penulis buku ditunjang oleh pengalaman dan pengetahuan yang ada.

5) Praduga, yaitu praduga berisi prasangka presensi terhadap penulis. Kemungkinan ada penulis yang sangat berambisi mengejar keuntungan ekonomis atau pendapat masyarakat yang mementingkan diri sendiri.

\section{d. Isi Resensi}

Kegiatan meresensi memuat aspek-aspek berikut.

1) Fisik buku

Bagian fisik buku meliputi judul, penulis atau editor, penerjemah (jika ada), penerbit, tebal buku, (bagian awal dan bagian inti). Bagian ini dikemukakan pada bagian awal.

2) Isi buku

Ulasan isi buku mencakup:

a) Tujuan penulisan buku, yang umumnya dicantumkan pada bagian pendahuluan.

b) Isi buku secara umum, yang terlihat dari daftar isi dan pendahuluan.

c) Penilaian kualitas isi, yang didasari kriteria kesahihan, kebermanfaatan, keandalan, kebaruan, kelebihan, kekurangan, keaslian, kelengkapan, dan sebagainya dapat juga membandingkan buku yang diresensi dengan buku lain, baik yang ditulis oleh penulis yang sama maupun yang berbeda.

3) Bahasa

Bahasa buku juga diulas karena berhubungan dengan pemahaman terhadap isi buku. Bahasa 
merupakan media untuk menyampaikan pesan. Oleh karena itu, bahasa menjadi salah satu unsur penting dalam resensi. Unsur bahasa yang diulas mencakup kelancaran berbahasa (penyampaian), istilah, kosakata, kalimat, gaya penyajian, dan keluwesan pemakaiannya.

4) Organisasi

Organisasi buku berkaitan dengan cara penataan ide buku. Organisasi dapat diulas dari segi kepaduan, urutan, keruntutan, kelogisan, dan kesistematisan.

5) Penulis buku

6) Latar belakang penulis disoroti, terutama latar belakang pendidikan, pengalaman menulis, keluasan wawasannya. Secara ringkas butir-butir umum yang disinggung dalam resensi di antaranya:

a) deskripsi buku: penerbit, penulis dan karyakaryanya, tebal buku, format, jumlah halaman, bab, dan sebagainya,

b) jenis buku yang diresensi: teori, pendidikan, petunjuk praktis,

c) sampul buku,

d) latar belakang penulisan dan pengalaman penulis,

e) judul,

f) sistematika,

g) ikhtisar,

h) keunggulan: bobot ilmiahan, keterbacaan, organisasi, kualitas, fungsi dalam pengembangan ilmu, dan

i) kualitas fisik: jenis kertas, jenis dan besarnya huruf. 


\section{e. Kualifikasi Peresensi}

Untuk dapat meresensi, peresensi perlu memiliki kualifikasi sebagai berikut.

1) Memiliki pengetahuan dalam bidangnya. Hanya seorang pakar di bidangnya yang mampu dan pantas menimbang buku tentang bidang yang digelutinya.

2) Memiliki kemampuan analisis. Peresensi mampu menemukan maksud penulis buku. Kemudian, membedakan hal-hal pokok dan hal yang kurang pokok, dan mempertimbangkan hubungannya.

3) Memiliki pengetahuan dalam acuan yang sebanding. Peresensi buku memiliki pengetahuan cukup di bidang lain yang relevan dengan buku yang akan diresensi.

\section{f. Nilai buku}

Nilai buku sebuah buku baru dikaitkan dengan fungsi buku bagi pembaca, yaitu nilai ekonomis, nilai spritual, nilai pendidikan, dan nilai profesi. Apabila buku mendorong pembaca memperoleh kreativitas baru yang secara ekonomis dapat dijual, hal tersebut menunjukkan bahwa buku itu memiliki nilai ekonomis. Apabila pembaca memeroleh informasi yang memberikan kepuasan batin, berarti buku itu mengandung nilai spritual. Apabila pembaca memeroleh keterampilan baru dari membaca buku itu, berarti buku itu memiliki nilai pendidikan. Demikian pula, jika pembaca dapat mengembangkan karier dan profesinya melalui buku itu, berarti buku tersebut memiliki nilai profesi.

\section{Rangkuman}

Secara umum dapat dikatakan bahwa rangkuman merupakan bentuk ringkas atau risalah dari tulisan asli. Secara khusus, rangkuman adalah bentuk tulisan yang 
mengikhtisarkan sesuatu dengan menggunakan kata-kata perangkum. Keterampilan menyusun rangkuman harus dimiliki oleh setiap orang ketika akan merangkum berita, surat, laporan, berita, diskusi, rapat, atau apa pun bentuk pembicaraan dalam sebuah pertemuan.

Ada beberapa hal yang harus diperhatikan oleh perangkum di antaranya:

a) rangkuman hanyalah mengungkapkan gagasan pokok atau bagian penting dari tulisan asli,

b) perangkum dapat menghilangkan contoh, ilustrasi, keterangan, dan penjelasan,

c) rangkuman disusun untuk beberapa kepentingan, seperti mendebat, mendukung, memperluas pemikiran penulis tulisan asli,

d) panjang rangkuman tidak boleh lebih dari sepertiga panjang tulisan asli,

e) perangkum tidak diperbolehkan mengubah sistematika atau urutan gagasan, dan

f) Perangkum harus menjaga keseimbangan dengan apa yang dibahas penulis.

\section{Sintesis}

Sintesis adalah kegiatan merangkum berbagai pengertian atau pendapat dari beberapa bacaan yang dipandang dari sudut pandang sendiri sehingga menjadi tulisan yang sama sekali baru. Untuk dapat menulis sintesis, kita perlu menguasai teknik membuat kutipan dan daftar acuan. Sintesis disusun berdasarkan kutipan yang dikumpulkan beserta pemahamannya. Jadi, sintesis merupakan simpulan berdasarkan pemahaman penulis atas beberapa sumber (Utorodewo dkk. dalam Wijayanti dkk. 2013: 184).

Ada beberapa hal yang perlu diperhatikan dalam membuat sintesis di antaranya: 
a) Bacalah sumber secara kritis,

b) Cari bagian yang akan ditekankan berdasarkan kepentingan tulisan,

c) Bersikap objektif terhadap pendapat ahli yang dikutip,

d) Pertajamlah sudut pandang, dan

e) Carilah kaitan antara bacaan tentang hal yang akan disoroti.

Membuat sintesis perlu dilatih dalam menulis ilmiah karena keterampilan ini memperlihatkan kemampuan penulis memahami bacaan dan mengaitkan antara bacaan sehingga terungkap pertalian dan perkembangannya. Cara mensintesiskan bacaan secara teknis di antaranya:

a) bacalah (bila perlu berkali-kali) dan pahami betul sumber bacaan yang akan dirujuk,

b) hubungkan sudut pandang penulis sintesis dengan sudut pandang yang terkandung dalam sudut sumber bacaan, dan

c) sajikan sintesis kepada pembaca dengan cara meyakinkan. 


\section{BAB V \\ KETERAMPILAN BERBICARA}

\section{A. Presentasi}

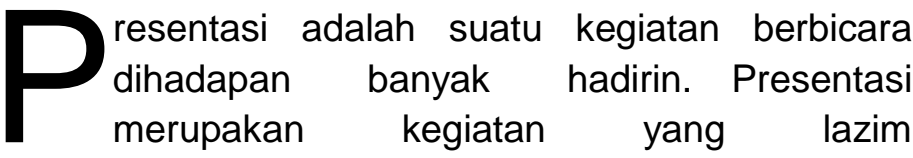

dilakukan untuk menyebarkan informasi, baik informasi konseptual maupun informasi procedural. Kemahiran presentasi merupakan kebutuhan, maka mahasiswa dilibatkan dalam melakukan presentasi, mulai dari menyusun bahan, membuat alat peraga dengan bantuan teknologi informasi, menyajikannya dan merevisi berdasarkan umpan balik dari hadirin.

\section{Presentasi ilmiah}

Presentasi ilmiah merupakan kegiatan yang lazim dilakukan dalam dunia ilmiah. Kegiatan itu berfungsi untuk menyebarkan informasi ilmiah. Karena mahasiswa merupakan intelektual yang berkewajiban menyebarkan ilmu yang dimilikinya, kemahiran untuk melakukan presentasi ilmiah merupakan suatu kebutuhan. Agar presentasi ilmiah dapat berjalan dengan efektif, ada kiatkiat yang perlu diterapkan, yakni (1) menarik minat dan perhatian peserta, (2) menjaga agar presentasi tetap fokus pada masalah yang dibahas, dan (3) menjaga etika ketika tampil di depan forum ilmiah.

Untuk menarik minat dan perhatian pada topik/masalah yang dibahas, seorang penyaji dapat menggunakan media yang menarik (media visual seperti gambar dengan warna yang menarik, ilustrasi, dll.), mengetahui latar belakang peserta, dan menjaga suara agar tidak monoton serta terdengar jelas oleh seluruh 
peserta yang berada di suatu ruangan. Untuk menjaga agar presentasi tetap fokus pada madalah yang dibahas, penyaji harus menaati bahan yang telah disiapkan dan memberi penjelasan singkat, padat, terhadap butir-butir inti.

Untuk menjaga etika dapat dilakukan dengan cara menghindari hal-hal yang dapat merugikan (menyinggung perasaan) orang lain. Butir-butir rinci tentang etika dan tata cara yang perlu ditaati dalam forum ilmiah akan diuraikan berikut ini.

\section{Tata Cara dan Etika Presentasi IImiah}

Presentasi ilmiah akan berhasil jika penyaji menaati tata cara yang lazim. Pertama, penyaji perlu memberi informasi kepada peserta secara memadai. Informasi tersebut akan dipahami dengan baik jika peserta memperoleh bahan tertulis, baik bahan lengkap maupun bahasan presentasi powerpoint. Jika diperlukan, bahan dapat dilengkapi dengan ilustrasi yang relevan. Apabila bahan ditayangkan, harus dipastikan bahwa semua peserta dapat melihat layar dan dapat membaca tulisan yang disajikan. Kedua, penyaji menyajikan bahan dalam waktu yang tersedia. Untuk itu, penyaji perlu merencanakan penggunaan waktu dan menaati panduan yang diberikan oleh moderator. Ketiga, penyaji menaati etika yang berlaku di forum ilmiah. Hal itu karena forum ilmiah merupakan wahana bagi ilmuwan dan akademisi dari berbagai disiplin ilmu saling asah otak dan hati serta bertukar berbagai informasi akademik, baik sebagai hasil pemikiran maupun hasil penelitian. Dalam forum tersebut ada beberapa peran yang dimainkan oleh aktor yang berbeda, yakni penyaji, pemandu (moderator), notulis, peserta, dan teknisi. Semua pihak wajib melakukan 
tugasnya dan menjaga agar jalannya presentasi ilmiah dapat berjalan dengan lancar sesuai dengan aturan main yang telah ditetapkan.

Etika berkaitan dengan keyakinan dan prinsip mengenai mana yang benar dan mana yang salah serta mana yang patut dan mana yang tidak patut. Satu nilai yang harus dipegang dalammenjaga etika adalah "menjaga perilaku agar tidak merugikan orang lain". Kerugian mencakup hak atau kesempatan, kehilangan muka, dan tersinggung perasaannya. Hak dalam forum ilmiah meliputi hak berbicara, hak membela dan mempertahankan pendapatnya, serta hak untuk mendapatkan pengakuan. Kehilangan muka dapat terjadi apabila aib atau kekurangan diungkapkan secara vulgar. Sementara itu, apabila seseorang telah melakukan sesuatu yang sangat berharga, ia mempunyai hak untuk mendapatkan pengakuan. Etika dalam forum ilmiah harus dijaga agar tujuan forum dapat tercapai dengan baik.

Hal lain yang perlu diperhatikan oleh penyaji dalam etika adalah kejujuran. Dalam dunia ilmiah, kejujuran merupakan butir etis terpenting. Setiap orang wajib bersikap sangat terbuka dalam segala hal menyangkut informasi yang dsajikan. Jika menyajikan data, penyaji harus secara jujur menyebutkan apakah data itu hasil penelitiannya ataukah diambil dari sumber lain. Jika diambil dari sumber lain, harus disebutkan secara lengkap sesuai dengan kelaziman dunia ilmiah.

Adapun etika yang harus dijaga oleh peserta antara lain adalah sebagai berikut. Pertama, setiap peserta harus jujur pada diri sendiri. Artinya, dia akan bertanya jika memang tidak tahu, akan mencari klarifikasi apabila masih bingung atau belum yakin, akan mengecek apakah pemahamannya sudah benar ataukah belum, dsb. 
Selain itu, setiap peserta wajib menghargai pendapat/gagasan orang lain dan hal ini mensyaratkan bahwa dia wajib menyimak apabila ada orang yang berbicara (atau bertanya). Misalnya, ketika orang lain telah mengusulkan gagasan, dia tidak akan berbicara seolah-olah dialah pengusul pertama gagasan tersebut. Ketika pertanyaan telah diajukan oleh peserta lain, dia tidak akan mengulangi pertanyaan itu. Ketika peserta lain telah menyatakan sesuatu dan dia menyetujuinya, dia dapat mengungkapkan dukungannya. Terkait dengan perilaku bertanya untuk memperoleh klarifikasi atau informasi, satu kewajiban penanya adalah menyimak jawaban dari penyaji. Akan lebih bagus jika penanya menunjukkan apresiasi positif terhadap jawaban yang telah diberikan. Apabila dengan terpaksa penanya meninggalkan ruangan sebelum jawaban diberikan, dia wajib meminta maaf dan meminta izin untuk meninggalkan ruangan.

Jalannya forum ilmiah banyak ditentukan oleh moderator sebagai pemandu. Etika yang harus dijaganya adalah bahwa dia harus adil. Artinya, semua peserta sedapat-dapatnya memperoleh kesempatan yang relatif sama dalam berpartisipasi aktif selama forum berlangsung. Keseimbangan tempat duduk peserta dan kesetaraan gender harus benar-benar dijaga. Demikian juga keseimbangan dalam hal waktu atau jumlah pertanyaan yang boleh diajukan oleh peserta. Selain adil, seorang moderator juga harus menaati jadwal atau waktu yang telah ditentukan. Pertama, moderator seyogianya tidak terlalu banyak mengambil waktu untuk berkomentar yang tidak fungsional. Kedua, moderator harus mengatur waktu yang digunakan oleh semua pihak, baik penyaji maupun peserta. Oleh sebab itu, moderator harus punya 
keberanian untuk menginterupsi dengan santun pembicaran seseorang agar taat waktu.

Semua hal yang terungkap selama forum, baik inti uraian penyaji, pertanyaan, maupun jawaban perlu dicatat secara rapi oleh notulis. Hasil catatan yang telah ditata ringkas sebaiknya dicetak dan dibagikan minimal kepada semua orang yang terlibat dalam forum tersebut. Hal ini memberi kesempatan bagi pemilik gagasan/konsep untuk meluruskannya jika ada hal-hal yang kurang tepat. Teknisi wajib memastikan bahwa peralatan teknologi yang digunakan bekerja dengan baik. Dia harus melakukan cek terakhir sebelum forum dimulai dan secara teratur mengontrol jalannya persidangan dari segi teknologi. Apabila terjadi sesuatu pada teknologi, dia harus secara cepat bertindak menyelamatkan jalannya kegiatan.

\section{Menyiapkan Bahan Presentasi Ilmiah dengan Multimedia}

Dalam era teknologi informasi, presentasi ilmiah dengan memakai multimedia sudah menjadi kebutuhan karena beberapa alasan. Pertama, presentasi akan menjadi menarik karena penyaji dapat membuat manuver dalam memvariasi teknik penyajian bahan, termasuk melalui animasi. Kedua, penyaji dapat menghemat waktu karena dapat mengoreksi bahan sewaktu-waktu diperlukan. Ketiga, penyaji dapat memberikan penekanan pada butir permasalahan yang dikehendaki secara menarik. Keempat, penyaji sangat dimudahkan karena membawa bahan dalam bentuk flashdisc. Kelima, bahan presentasi dapat sangat ringkas sehingga membantu peserta menangkap esensi bahan yang dibahas. Keenam peserta dapat langsung mengopi file presentasi yang 
diperlukan. Agar manfaat multimedia dapat dinikmati, presentasi multimedia perlu disiapkan dengan baik.

Dalam menyiapkan presentasi multimedia, langkah-langkah yang dapat ditempuh adalah sebagai berikut.

a. Tentukan butir-butir terpenting bahan yang dibahas. Penyebutan butir hendaknya tidak boleh terlalu singkat, tetapi juga tidak boleh terlalu elabratif karena elaborasi akan dilakukan secara lisan oleh penyaji.

b. Atur butri-butir tersebut agar alur penyajian runtut dan runut (koheren dan kohesif).

c. Kerangka pikir perlu diungkapkan/disajikan dalam diagram atau bagan alir untuk menunjukkan alur penalarannya.

d. Tuliskan semuanya dalam bingkai power point dengan ukuran huruf atau gambar yang memadai.

e. Pilih rancangan slide yang cocok (ingat, kontras warna dan animasi sangat penting. Namun, jangan sampai bahwa terjadi dekorasi lebih menarik daripada butir bahasan).

f. Uji coba tayang untuk memastikan bahwa semua bahan yang disajikan dalam slide dapat terbaca oleh peserta dalam ruangan yang tersedia.

g. Cetak bahan dalam slide tersebut untuk digunakan sebagai pegangan dalam penyajian.

\section{Melaksanakan Presentasi IImiah}

Presentasi ilmiah pada dasarnya adalah mengomunikasikan bahan ilmiah kepada peserta forum ilmiah. Oleh karena itu, dalam presentasi ilmiah berlaku prinsipprinsip komunikasi. Beberapa prinsip komunikasi berikut dapat dipertimbangkan.

a. Mengurangi gangguan komunikasi secara antisipatif. 
1) Memastikan kecukupan pencahayaan dan ruang gerak.

2) Memperhatikan tingkat kapasitas peserta ketika memilih bahasa dan media.

3) Menghindari kemungkinan multitafsir ungkapan yang dipilih.

4) Berpikir positif tentang peserta.

5) Membuat peserta dihormati dan dihargai.

6) Mempertimbangkan budaya peserta.

7) Bersikap terbuka terhadap perbedaan sikap dan pendapat orang lain.

8) Memastikan bahwa pakaian yang akan dipakai tepat pilihan dari segi situasi formal dan budaya setempat.

b. Memaksimalkan efektivitas dalam proses presentasi.

1) Memastikan bahwa suaranya dapat didengar oleh semua peserta.

2) Memastikan bahwa penyaji dapat melihat semua peserta.

3) Menjadi penyimak/pendengar yang baik jika ada peserta yang bertanya.

4) Memberi kesempatan kepada peserta untuk bertanya.

5) Mendorong peserta untuk aktif terlibat.

6) Menggunakan media yang menarik dan tepat guna.

\section{B. Seminar}

Kata seminar berasal dari kata Latin semin yang berarti "benih". Jadi, seminar berarti " tempat benih-benih kebijaksanaan". Seminar merupakan pertemuan ilmiah yang dengan sistematis mempelajari suatu topik khusus di bawah pimpinan seorang ahli dan berwenang dalam bidang tersebut. Seminar merupakan suatu pertemuan atau persidangan untuk 
membahas suatu masalah. Pertemuan atau persidangan dalam seminar biasanya menampilkan satu atau beberapa pembicaraan dengan makalah atau kertas kerja masingmasing. Seminar biasanya diadakan untuk membahas suatu masalah secara ilmiah. Yang berpartisipasi pun orang yang ahli dalam bidangnya. Seminar tentang pemasaran suatu produk, tentu dihadiri oleh para pakar bidang pemasaran. Seminar pendidikan tentu saja dihadiri oleh para ahli pendidikan. Sementara itu, peserta berperan untuk menyampaikan pertanyaan, ulasan, dan pembahasan sehingga menghasilkan pemahaman tentang suatu masalah. Kegiatan seminar ini juga lazim dilaksanakan dalam kelas baik di sekolah maupun perguruan tinggi.

Dalam menyelenggarakan seminar kelas, susunlah terlebih dahulu organisasi peleksanaannya. Seorang yang lain ditugasi sebagai pembahas khusus dari makalah yang disajikan. Seorang ditugasi sebagai moderator. Guru sebagai narasumber dan satu atau dua orang bertugas sebagai notulis yang bertugas menyusun laporan. Seminar bukan diadakan untuk menetapkan suatu keputusan terhadap masalah yang dibicarakan. Seminar hanya membahas cara pemecahan masalah. Karena inti dari sebuah seminar merupakan sebuah diskusi, laporan seminar pun merupakan laporan hasil diskusi. Oleh karena itu, laporan seminar hendaknya berisi hal-hal yang penting saja. Seminar melahirkan rekomendasi kepada pihak-pihak tertentu sebagai sumbang saran dari permasalahan yang ada.

Susunan acara seminar dapat dibuat seperti berikut.

1. Laporan ketua.

2. Penyajian ketua.

3. Pembahasan oleh pembahas.

4. Diskusi.

5. Penyimpulan. 


\section{Penutup.}

Selain seminar yang telah diuraikan sebelumnya, masih terdapat beberapa bentuk kegiatan lainnya yang menyerupai pelaksanaan seminar. Adapun perbedaannya menyangkut soal teknis penyelenggaraan seperti di bawah ini:

a. Diskusi

Kata diskusi berasal dari bahas Latin discutio atau discusum yang berarti bertukar pikiran. Dalam bahasa Inggris digunakan kata discussion yang berarti perundingan atau pembicaraan. Dari segi istilah, diskusi berarti perundingan/bertukar pikiran tentang suatu masalah: untuk memahami, menemukan sebab terjadinya masalah, dan mencari jalan keluarnya. Diskusi ini dapat dilakukan oleh dua-tiga orang, puluhan, dan bahkan ratusan orang. Diskusi adalah sebuah proses tukar menukar informasi, pendapat, dan unsur unsur pengalaman secara teratur dengan maksud untuk mendapatkan pengertian bersama yang lebih jelas, lebih teliti tentang sesuatu atau untuk mempersiapkan dan merampungkan kesimpulan/pernyataan/keputusan. Di dalam diskusi selalu muncul perdebatan. Debat ialah adu argumentasi, adu paham dan kemampuan persuasi untuk memenangkan pemikiran/paham seseorang.

b. Simposium

Simposium merupakan pertemuan terbuka dengan beberapa pembicara yang menyampaikan ceramah pendek mengenai aspek yang berbeda tetapi saling berkaitan tentang suatu masalah. Simposium dipimpin oleh seorang ketua yang bertugas mengatur jalannya diskusi. Pendengar bertanya dan para ahli menjawab.

c. Kolokium. 
Pada kolokium, beberapa ahli diundang untuk memberi jawaban terhadap pertanyaan yang diajukan pendengar mengenai topik yang ditentukan. Bedanya dengan simposium, dalam kolokium para ahli tidak mengajukan (makalah) prasaran.

\section{Berpidato dalam situasi formal}

Berpidato merupakan salah satu wujud kegiatan berbahasa lisan. Sebagai wujud berbahasa lisan, berpidato mementingkan ekspresi gagasan dan penalaran dengan menggunakan bahasa lisan yang didukung oleh aspek-aspek nonkebahasaan (ekspresi wajah, gesture, kontak pandang,dll.). Dengan demikian berpidato adalah kegiatan menyampaikan gagasan secara lisan dengan menggunakan penalaran yang tepat serta memanfaatkan aspek-aspek nonkebahasaan yang dapat mendukung keefisienan dan keefektifan pengungkapan gagasan kepada orang banyak dalam suatu acara tertentu.

\section{Pengertian pidato}

Pidato adalah berucap didepan umum untuk tujuan tertentu. (Kamus Lengkap Bahasa Indonesia, hal 455 : 2005). Jadi, Pidato adalah sebuah kegiatan berbicara atau berorasi untuk menyatakan pendapatnya, atau memberikan gambaran tentang suatu hal yang ditujukan untuk orang banyak. Pidato biasanya dibawakan oleh seorang yang memberikan orasi-orasi, dan pernyataan tentang suatu hal/peristiwa yang penting dan patut diperbincangkan. Pidato adalah salah satu teori dari pelajaran bahasa indonesia. Pidato banyak jenisnya, di antaranya, pidato sambutan yang disampaikan pada awal sebuah acara atau pidato kenegaraan yang disampaikan oleh presiden. Pidato 
yang baik dapat memberikan suatu kesan positif bagi orang-orang yang mendengar pidato tersebut.

Kemampuan berpidato atau berbicara yang baik di depan umum dapat membantu untuk mencapai jenjang karier yang baik. Contoh pidato yaitu seperti pidato kenegaraan, pidato menyambut hari besar, pidato pembangkit semangat, pidato sambutan acara atau event, dan lain sebagainya. Dalam berpidato, penampilan, gaya bahasa, dan ekspresi kita hendaknya diperhatikan serta kita harus percaya diri menyampaikan isi dari pidato kita, agar orang yang melihat pidato kita pun tertarik dan terpengaruh oleh pidato yang kita sampaikan. Pidato adalah semacam cara penyampaian gagasan, ide-ide, tujuan, pikiran serta informasi dari pihak pembicara kepada banyak orang (audience) dengan cara lisan. Pidato juga bisa diartikan sebagai the art of persuasion, yaitu sebagai seni membujuk/mempengaruhi orang lain. Berpidato sangat erat hubungannya dengan retorika (rhetorica), yaitu seni menggunakan bahasa dengan efektif.

\section{Tujuan Pidato}

Adapun tujuan pidato secara umum adalah :

a. Informatif, yaitu bertujuan untuk memberikan laporan, informasi, pengetahuan atau sesuatu yang menarik untuk orang lain / pendengar.

b. Persuasif dan instruktif, bertujuan untuk mempengaruhi, mendorong, meyakinkan dan mengajak pendengar untuk melakukan sesuatu hal dengan suka rela.

c. Edukatif, yaitu berupaya untuk menekankan pada aspek-aspek pendidikan. 


\section{d. Entertain, bertujuan memberikan penyegaran kepada pendengar dan membuat pendengar itu senang dan puas dengan pidato yang disampaikan.}

\section{Kriteria Berpidato yang Baik}

Pidato yang baik ditandai oleh kriteria (a) isinya sesuai dengan kegiatan yang sedang berlangsung, (b) isinya menggugah dan bermanfaat bagi pendengar, (c) isinya tidak menimbulkan pertentangan sara, (d) isinya jelas, (e) isinya benar dan objektif, (f) bahasa yang digunakan mudah dipahami pendengarnya, dan (g) disampaikan secara santun, rendah hati, dan bersahabat.

Seseorang harus menguasai unsur kebahasaan secara baik dan juga unsur nonkebahasaan, misalnya keberanian, ketenangan, kesanggupan melakukan reaksi yang cepat dan tepat, kesanggupan menyampaikan gagasan atau ide secara lancar dan teratur, dan kesanggupan memperlihatkan sikap dan gerak-gerik yang tidak canggung.

Menurut Gorys Keraf, ada tujuh langkah yang perlu diperhatikan dalam mempersiapkan pidato yang baik.
a. Menentukan topik dan tujuan
b. Menganalisis pendengar dan situasi
c. Memilih dan menyimpitkan topic
d. Mengumpulkan bahan
e. Membuat kerangka uraian
f. Menguraikan secara mendetail
g. Melatih dengan suara nyaring

Ketujuh langkah tersebut diperingkas menjadi tiga langkah, yaitu menelitih masalah ( $a, b$, dan $c)$, menyusun uraian (d, e, dan f), dan mengadakan latihan (g).

4. Tata Cara dan Etika Berpidato

Tata cara berpidato merujuk kepada langkah-langkah dan uraian untuk memula, mengembangkan, dan mengakhiri 
pidato. Etika berpidato merujuk kepada nilai-nilai kepatutan yang perlu diperhtikan dan dijunjung ketika berpidato. Langkah-langkah dan uruttan berpidato secara umum diawali dengan pembukaan, sajian isi, dan penutup.

a. Pembukaan biasanya berisi sapaan kepada pihakpihak yang diundang atau yang hadir dalam suatu acara. Beberapa cara yang dapat digunakan seorang pembicara untuk membuka pidatonya: (1) Dengan memperkenalkan diri. (2) Membuka pidato dengan humor. (3) Membuka pidato dengan pendahuluan secara umum.

b. Sajian isi merupakan hasil penjabaran gagasan pokok, sajian isi perlu di rinci sesuai dengan waktu yang disediakan. Pada bagian ini pokok pembahasan ditampilkan dengan terlebih dahulu mengemukakan latar belakang permasalahannya.Pokok pembicaraan dikemukakan sedemikian rupa sehingga tampak jelas kaitannya dengan kepentingan para audience.

c. Pembahasan. Bagian ini merupakan kesatuan, yang berisi alasan-alasan yang mendukung hal-hal yang dikemukakan pada bagian isi. Pada bagian ini biasanya berisi berbagai hal tentang penjelasan, alasan-alasan, bukti-bukti yang mendukung, ilustrasi, angka-angka dan perbandingan, kontras-kontras, bagan- bagan, model, dan humor yang relevan.

d. Penutup pidato berisi penegasan kembali gagasan pokok yang telah dipaparkan dalam sajian isi, harapan, dan ucapan terima kasih atas partisipasi semua pihak dalam acara sedang berlangsung. Penutup pidato ini terdiri atas bagian simpulan dan harapan- harapan. 1) Simpulan. Sebuah teks pidato yang baik harus memuat sebuah kesimpulan. Kesimpulan tersebut dapat disampaikan langsung oleh orang yang berpidato 
(tersurat), dapat juga pendengar menafsirkannya sendiri (tersirat). Jika berpidato di hadapan anak-anak, umumnya simpulan disampaikan secara langsung sebagai penekanan isi pidato. 2) Harapan-harapan. Dalam sebuah teks pidato, harapan-harapan dari orang yang berpidato pun sangat penting. Harapanharapan ini berisi dampak positif yang diharapkan terjadi pada pendengar pidato setelah mendengarkan pidato yang disampaikan.

e. Salam penutup. Biasanya salam penutup ini dibarengi dengan ucapan terima kasih, permohonan maaf, dan ditutup dengan salam penutup.

Menurut Gorys Keraf, ada tidaknya persiapan sesuai dengan cara yang dilakukan waktu persiapan ada empat macam metode pidato:

1) Impromtu (serta merta) yaitu membawakan pidato tanpa persiapan dan hanya mengandalkan pengalaman dan wawasan. Biasanya dalam keadaan darurat tak terduga dan banyak menggunakan teknik serta merta. Keuntungan dari metode ini komunikasi pembicara dengan pendengar lebih baik dan tidak memerlukan banyak waktu untuk menghafal.

2) Ekstemporan yaitu teknik berpidato dengan menjabarkan materi pidato yang terpola secara lengkap. Maksud dari terpola yaitu materi yang akan disampaikan harus disiapkan garis-graris besar isinya dengan menuliskan hal-hal yang dianggap paling penting untuk disampaikan. Keuntungannya: komunikasi pendengar akan berkurang karena pembicara beralih kepada usaha untuk mengingat kata-kata yang akan disampaikan dan gerak serta isyarat dapat diintegrasikan dengan uraian. Kerugiannya: kata-kata yang akan digunakan dapat 
dipilih dengan sebaik-baiknya dan pembuatan naskah membutuhkan waktu lebih lama.

3) Memoriter merupakan metode pidato dengan menulis pesan atau gagasan yang akan disampaikan dan kemudian menghafalkannya kata demi kata. Kerugiannya:

a) Pembicara tidak dapat melihat pendengar dengan baik, karena harus fokus juga kepada naskah pidatonya.

b) Komunikasi pendengar akan berkurang karena pembicara tidak berbicara langsung kepada mereka.

c) Kefasihan terhambat karena kesukaran memilih kata-kata.

Sedangkan keuntunganya:

a) Tidak ngawur atau asal-asalan.

b) Kefasihan dalam berbicara dapat dicapai.

c) Pernyataan yang disampaikan dapat dihemat.

d) Kata-kata yang digunakan dapat dipilih dengan sebaik-baiknya.

e) Manuskrip dapat diperbanyak.

Nilai-nilai yang perlu diperhatikan dalam berpidato yaitu janganlah menyinggung perasaan orang lain tetapi sebaliknya berupa menghargai dan membangun optimisme bagi pendengarnya, keterbukaan, kejujuran, empati, dan persahabatn perlu diusahakan dalam berpidato. Adapun tata krama dalam berpidato diantarnya:

1) Jika berpidato di hadapan umum, hendaknya memperhatikan tiga hal berikut ini:

a) berpakaian dengan rapi dan bersih, tetapi, tidak bergayapamer dengan memakai perhiasan atau pakaian yang berlebihan. 
b) menggunakan kata-kata sopan dan jangan memperlihatkan keangkuhan, kesombongan, atau, kepongahan, tetapi dengan rendah hati.

c) jika pidato panjang, agar tidak membosankan pendengar hendaknya diselingi humor, namun humor itu harus sopan.

2) Jika berpidato di hadapan wanita atau sebagian besar wanita dan yang berpidato pria, perhatikanlah kata-kata yang digunakan, hendaknya jangan sampai menyinggung perasaan.

3) Bila berpidato di hadapan orang-orang terkemuka, hendaknya mempersiapkan diri dengan sempurna; dengan demikian keyakinan kita akan tumbuh; selain itu kita tidak perlu merasa rendah diri.

4) Jika berpidato di hadapan sesama golongan, kita harus terbuka dan terus terang dan dapat agak santai, namun jangan melupakan tata krama.

5) Jika yang mendengarkan pidato kita itu pelajar atau mahasiswa, kita harus mampu menyakinkan mereka argumentasi yang logis.

6) Jika berpidato di hadapan pemeluk suatu agama, kita harus menjaga jangan sampai ada satu ucapan pun yang menyinggung martabat suatu agama.

7) Jika yang mendengarkan pidato kita itu masyarakat desa, gunakanlah kata-kata atau kalimat yang sederhana sehingga pidato kita itu mudah dimengerti.

5. Menulis Naskah Berpidato

Menulis naskah pidato perlu dilakukan apabila kegiatan pidato yang akan dilakukan memang dipersiapkan sebelumnya. Akan tetapi, apabila kegiatan berpidato itu dilakukan secara spontan tentu tidak perlu menulis naskah pidato sebelum kegiatan pidato dilakukan. Menulis naskah 
pidato hakikatnya dalah menuangkan gagasan ke dalam bentuk bahasa tertulis yang siap dilisankan melalui kegiatan berpidato. Pilihan kosa kata dan kalimat-kalimat serta paragraf dalam menulis naskah pidato sesungguhnya tidak jauh berbeda apabila dibandingkan dengan kegiatan menulis untuk menghasilkan naskah lain. Situasi resmi atau kurang resmi akan menentukan pilihan kosa kata dalam menulis naskah pidato. Dengan demikian, sekalipun naskah pidato itu merupakan bahan tulis yang akan dilisankan, sehingga konteks kelisanan perlu diperhatikan.

\section{Menyunting naskah pidato}

Isi, bahasa, dan penalaran dalam naskah pidato menjadi sasaran penyuntingan. Isinya dicermati kembali apakah telah sesuai dengan tujuan pidato, calon pendengar, dan kegiatan yang digelar. Selain itu, isinya juga dipastikan apakah benar, representatif, dan mengandung informasi yang relevan dengan konteks pidato. Penyuntingan terhadap bahasa diarahkan pada pilihan kosa kata, kalimat, dan penyusunan paragraf. Ketepatan pilihan kosa kata, kalimat, dan satuansatuan gagasan dalam paragraf menjadi perhatian utama dalam kegiatan penyuntingan ini. Sedangkan penalaran dalam naskah pidato juga disunting untuk memastikan apakah isi dalam naskah pidato telah dikembangkan dengan menggunakan penalaran yang tepat, misalnya dengan pola induktif, deduktif, dan campuran.

7. Menyempurnakan naskah pidato berdasarkan suntingan

Menyempurnakan naskah pidato setelah disunting, baik oleh penulis sendiri maupun orang lain, perlu dilakukan. Penyempurnaan itu diarahkan kepada aspek isi, bahasa, dan penalaran. Penyempurnaan aspek bahasa dilakukan dengan mengamati kosa kata yang lebih tepat dan menyempurnakan 
kalimat dengan memperbaiki struktur dan gagasannya. Sementara itu penyempurnaan paragraf dilakukan dengan memperbaiki koherensi dan kohesi peragraf. Untuk itu, penambahan kalimat, penyempurnaan kalimatatau penghilangan kalimat perlu dilakukan.

8. Sistematika berpidato

Secara garis besar sistematika berpidato adalah seperti berikut ini.

a. Mengucapkan salam pembuka dan menyapa hadirin;

b. Menyampaikan pendahuluan yang biasanya dilahirkan dalam ucapan terima kasih, atau ungkapan kegembiraan atau rasa syukur;

c. Menyampaikan isi pidato yang diucapkan dengan jelas dengan menggunakan bahasa indonesia yang baik dan benar dan dengan gaya bahasa yang menarik;

d. Menyampaikan kesimpulan dari isi pidato supaya mudah diingat oleh pendengar;

e. Menyampaikan harapan yang berisi anjuran atau ajakan kepada pendengar untuk melaksanakan isi pidato; dan

f. Menyampaikan salam penutup.

\section{Teknik Berpidato Yang Efektif}

Pidato dapat disampaikan dalam dua cara, yakni pidato tanpa teks dan pidato dengan membacakan teks. Pidato tanpa teks disebut juga dengan pidato ekstemporan. Pidato ini dilakukan dengan cara menuliskan pokok-pokok pikirannya. Kemudian ia menyampaikannya dengan kata-katanya sendiri. la menggunakan catatan itu untuk mengingatkannya tentang urutan dan ide-ide penting yang hendak disampaikan, metode ekstemporan dianggap paling baik, karena itu pidato Inilah yang sering digunakan oleh banyak pembicara. Pidato dengan membacakan teks disebut juga pidato naskah. Dalam hal ini 
juru pidato membacakan pidato yang telah dipersiapkannya terlebih dahulu. Pidato dengan membacakan teks, akan terkesan kaku apabila kita tidak pandai-pandai dalam menyampaikannya. Apalagi bila kegiatan tersebut tanpa disertai dengan ekspresi, intonasi suara,dan kesiapan mental yang memadai, pidato yang kita sampaikan betul-betul tidak menarik. Efektivitas pidato dipengaruhi oleh beberapa hal, di antaranya:

a. Lafal adalah ucapan bunyi-bunyi bahasa. Setiap bahasa cenderung mempunyai karakteristik bunyi tertentu, oleh karena itu ketika berpidato dalam bahasa Indonesia pembicara harus menggunakan lafal baku yang dimiliki oleh bahasa Indonesia.

b. Intonasi mempunyai dua fungsi pokok: Pertama, intonasi menentukan makna kalimat yang kita ucapkan, dengan intonasi yang berbeda, klausa sama dapat menjadi kalimat berita, tanya, atau perintah hanya karena perbedaan intonasi kalimat. Berdiri dengan rileks, jangan tegang atau kaku. Kedua, intonasi dapat mempengaruhi daya persuasi pidato. Dengan penggunaan intonasi yang tepat pembawa pidato dapat membujuk, mempengaruhi atau meyakinkan pendengarnya. Oleh karena itu daya tarik pidato juga sangat ditentukan ketetapan penggunaan intonasinya.

c. Nada adalah tinggi atau rendahnya suara ketika berpidato. Kualitas nada biasanya ditentukan oleh cepat atau lambatnya pita suara bergetar, jika pita suara bergetar cepat maka nada yang dihasilkan akan tinggi, tetapi jika pita suara bergetar lambat, nada yang dihasilkan adalah rendah. Dalam proses berpidato nada mempunyai fungsi yang cukup penting, walaupun dalam bahasa Indonesia nada tidak bersifat distingtif, tatapi penggunaannya dapat mempengaruhi daya tarik dan efektifitas pidato. Untuk itu penggunaan nada tertentu dalam pidato tidak bisa 
sewenang- wenang, penggunaannya didasari oleh kesadaran akan fungsinya di dalam mengefektifkan proses penyampaian dan pemahaman pidato. Pidato yang efektif biasanya menggunakan nada yang bervariasi. Variasi nada ini sejalan dengan beragam kalimat yang digunakan dalam pidato itu, ketika isi pidato mengajak seseorang untuk bangkit dari keterpurukan, maka nada tinggi lebih tepat untuk digunakan. Namun manakala beralih kepada duka cita, maka nada tinggi bukanlah pilihan yang tepat. Dengan kata lain penggunaan nada yang tinggi atau rendah sangat ditentukan oleh isi kalimat yang dituturkan serta harus sesuai dengan keadaan.

d. Sikap merupakan unsur nonbahasa, tetapi sangat mempengaruhi efektifitas pidato, sikap merupakan suatu bentuk evaluasi atau reaksi seseorang terhadap diri dan lingkungannya. Berikut ini beberapa bentuk sikap yang baik dilakukan pada saat berpidato :

1) Sopan.

2) Menghargai pendengar dan menciptakan rasa bersahabat.

3) Pandangan harus tertuju kepada seluruh pendengar.

4) Hindarkan gerakan yang dapat mengganggu konsentrasi pendengar.

5) Ciptakan rasa humor yang sehat.

6) Gunakan mimik dan gerakan tubuh secara wajar.

10. Faktor penunjang keefektifan berpidato

Ada empat hal yang perlu diperhatikan agar pidatonya sukses yaitu:

a. Pembicara dituntut seseorang yang bermoral. Jika pembicara bermoral tidak baik dan diketahui oleh pendengar, maka pendengar akan mencemooh. 
b. Pembicara hendaknya sehat jasmani dan rohani sehingga penampilannya dapat bersemangat, gagah, dan simpatik. Jangan sekali-kali menunjukkan fisik yang lemah dihadapan khalayak.

c. Sarana yang diperlukan hendaknya cukup menunjang, misalnya publikasi; jika pidato disampaikan di hadapan massa, pengeras suara yang memadai, waktu, dan tempat harus sesuai.

d. Jika berpidato di hadapan massa, harus diperhatikan; volume suara, tingkat pengetahuan massa, keadaan sosial, kebiasaan, adat istiadat, dan agama, waktu berbicara tidak begitu lama, pembicara harus sabar dan menyesuaikan gaya dengan massa. 


\section{DAFTAR PUSTAKA}

Amir, Muhammad. 2008. Pendidikan Keterampilan Berbahasa Indonesia.Makassar: FKIP UNISMUH.

Arifin, Zainal. 2005. Dasar-Dasar Penulisan Karangan IImiah. Jakarta: PT Grasindo.

Barnawi \& M. Arifin. 2015. Teknik Penulisan Karya IImiah. Jakarta: PT Grasindo.

Belt, P. Mottenen M. \& Harkonen J. 2011. Tips for Writing Scienific Journal Articles. Finlandia: University of Oulu.

Depdiknas, Pusat Bahasa. 2008. Kamus Besar Bahasa Indonesia. Jakarta: Gramedia.

Firman. 2015. Terampil Menulis Karya Ilmiah. Makassar: Aksara Timur

Fachruddin, A.E. 1994. Dasar-Dasar Keterampilan Menulis. Ujung Pandang: Badan Penerbit IKIP Ujung Pandang.

Ghazali, Syukur. 2010. Pembelajaran Keterampilan Berbahasa: dengan Pendekatan KomunikatifInteraktif. Bandung: PT Refika Aditama.

Gie, The Liang. 2002. Terampil Mengarang. Yogyakarta: ANDI.

Keraf, Gorys. 1989. Komposisi. Jakarta: Nusa Indah.

Hamsa, A. 2009. Efektivitas Pembelajaran Menulis Akspositori Berbasis Media Audio, Gambar, dan Lingkungan pada Siswa Kelas II SMP Negeri 21 Makassar. Disertasi Malang: PPs Universitas Negeri Malang.

Montefiore, Simon Sebag. 2009. Pidato-pidato yang mengubah dunia. Surabaya: Erlangga.

Nurdjan, Sukirman. 2015a. "Korelasi antara Aspek Pembelajaran Kreatif Produktif dan Hasil Kemampuan Menulis Akademik (Karya Tulis Ilmiah) Mahasiswa IAIN Palopo". LP2M IAIN Palopo: Palopo. 
Nurdjan, Sukirman. 2015b. Cara Kreatif Menulis Karya Ilmiah. Makassar: Aksara Timur.

Ramly, dkk. 2013. Pengembangan Kepribadian Bahasa Indonesia. Makassar: UNM.

Soedarso. 1989. Sistem Membaca Cepat Efektif. Jakarta: PT Gramedia.

Suparno \& Mohammad Yunus. 2002. Keterampilan Dasar Menulis. Jakarta: Universitas Terbuka.

Syafruddin. 2012. "Handout Mata Kuliah Bahasa dan

Penulisan Karya Ilmiah". Makassar: Program Studi Pendidikan Bahasa Indonesia FKIP Unismuh Makassar.

Tang, Muhammad Rafi dkk. 2008. Mata Kuliah Pengembangan Kepribadian Bahasa Indonesia. Makassar: Badan Pengembangan Bahasa dan Sastra Indonesia dan Daerah FBS UNM.

Tarigan, Henry Guntur. 2008. Menulis Sebagai Suatu Keterampilan Berbahasa. Bandung: Angkasa.

Wibowo, Mungin E. dkk., 2006. Panduan Penulisan Karya Ilmiah. Semarang: Unes.

Widyamartaya, A. 1992. Seni Menuangkan Gagasan.

Yogyakarta: Kanisius.

Wijayanti, Sri Hapsari dkk. 2013. Bahasa Indonesia Penulisan dan Penyajian Karya ilmiah. Jakarta: PT RajaGrafindo Persada. 